GA-A15647

\title{
GAS COOLED FAST BREEDER REACTOR DESIGN FOR A CIRCULATOR TEST FACILITY (MODIFIED HTGR CIRCULATOR TEST FACILITY)
}

\author{
by \\ PROJECT STAFFS \\ of
}

The General Atomic Company

San Diego, California

and

The Ralph M. Parsons Company

Pasadena, California

(Under General Atomic Subcontract 667602)

Prepared under

Project Agreement No. DE-AT03-76SF1023

for the

San Francisco Operations Office

Department of Energy

General Atomic Project 6112

OCTOBER 1979

\section{GENERAL ATOMIC COMPANY}




\section{DISCLAIMER}

This report was prepared as an account of work sponsored by an agency of the United States Government. Neither the United States Government nor any agency Thereof, nor any of their employees, makes any warranty, express or implied, or assumes any legal liability or responsibility for the accuracy, completeness, or usefulness of any information, apparatus, product, or process disclosed, or represents that its use would not infringe privately owned rights. Reference herein to any specific commercial product, process, or service by trade name, trademark, manufacturer, or otherwise does not necessarily constitute or imply its endorsement, recommendation, or favoring by the United States Government or any agency thereof. The views and opinions of authors expressed herein do not necessarily state or reflect those of the United States Government or any agency thereof. 


\section{DISCLAIMER}

Portions of this document may be illegible in electronic image products. Images are produced from the best available original document. 


\section{NOTICE}

This report was prepared as an account of work sponsored by the United States Government. Neither the United States nor the Department of Energy, nor any of their employees, nor any of their contractors, subcontractors, or their employees, makes any warranty, express or implied, or assumes any legal liability or responsibility for the accuracy, completeness, or usefulness of any information, apparatus, product, or process disclosed, or represents that its use would not infringe privately owned rights. 
GA-A15647

\title{
GAS COOLED FAST BREEDER REACTOR DESIGN FOR A CIRCULATOR TEST FACILITY (MODIFIED HTGR CIRCULATOR TEST FACILITY)
}

\author{
by \\ PROJECT STAFFS
}

of

The General Atomic Company

San Diego, California

and

The Ralph M. Parsons Company

Pasadena, California

(Under General Atomic Subcontract 667602)

Prepared under

Project Agreement No. DE-AT03-76SF1023

for the

San Francisco Operations Office

Department of Energy

General Atomic Project 6112

OCTOBER 1979 


\section{GENERAL ATOMIC COMPANY STAFF}

\section{CIRCULATOR TEST FACILITY PRINCIPAL ENGINEER:}

M. B. DOLPHIN

\section{MAJOR CONTRIBUTORS}

J. P. HUNTSINGER

D. L. SONN 
ABSTRACT 
ABSTRACT

The Gas-Cooled Fast Breeder Reactor (GCFR) Demonstration Plant uses helium loops to transfer heat from the reactor core to the steam generators. Helium flow in each loop is provided by a circulator driven a 30,000 horsepower electric motor.

Experimental verification of the designs for the circulator, circulator service system, main and pony motors, main and pony motor controllers, loop isolation valve and instrumentation and control systems are needed to demonstrate that operational and safety requirements are met. In addition, each production circulator must be acceptance tested prior to installation in the plant. The test facility will also accommodate the connection of additional helium loop equipment and piping to permit flow testing of other components.

A GCFR helium circulator test facility sized for full design conditions is proposed for meeting the above requirements. The circulator will be mounted in a large vessel containing high pressure helium which will permit testing at the same power, speed, pressure, temperature and flow conditions intended in the demonstration plant. The electric drive motor for the circulator will obtain its power from an electric supply and distribution system in which electric power will be taken from a local utility.

The conceptual design decribed in this report is the result of close interaction between the General Atomic Company (GA), designer of the GCFR, and The Ralph M. Parson Company, architect/engineer for the test facility. A realistic estimate of total project cost is presented, together with a schedule for design, procurement, construction, and inspection. The total estimated cost of this facility escalated to the period of spending, including Title I, II and III engineering, site work, building modificatiun, special facilities, utilities, standard equipment, and contingency is $\$ 18,902,000$. Expense funded operating and capitol equipment costs are also presented.

This report is provided as support for a DOE Schedule 44 Construction Project Data Sheet request for fiscal year 1982 line item funding of the GCFR Circulator Test Facility. 


\section{TABLE OF CONTENTS}




\section{GAS COOLED FAST BREADER REACTOR DESIGN FOR A CIRCULATOR TEST FACILITY (MODIF IED HTGR CIRCULATOR TEST FACILITY)}

TABLE OF CONTENTS

$\underline{\text { Page }}$

ABSTRACT

1 PUR POSE

2 PROJECT SCOPE

2.1 . Introduction

2.2 Test Program Overview

2-1

2.3 Organizational Responsibilities

$2-1$

2.4 Facility Overview

$2-3$

$2-4$

3 DESIGN REQUIREMENTS

3.1 Test and Support Systems Performance Requirements 3-1

3.2 Facility Requirements

4 PROJECT DESCRIPTION

4.1 Test Hardware

4.1.1 Hellum Circulator 4-1

4.1.2 Diffuser 4-1

4.1.3 Isolation Valve $4-1$

4.1.4 Thermal Barrier 4-2

4.1.5 Main Circulator Motor 4-2

4.1.6 Pony Motor 4-2

4.1.7 Main Circulator Motor Controller 4-2

4.1.8 Pony Motor Controller 4-3

4.1.9 Circulator Service Module 4-3

4.1.10 Circulator Instrumentation $4-3$

4.2 Test Systems

4.2.1 Helium Loop 4-3

4.2.2 Rapid Depressurization System 4-6

4.2.3 Provision for Future Testing 4-6

4.3 Support Systems

4.3.1 Dowtherm System 4-7

4.3.2 Helim Supply and Storage System 4-7

4.3.3 Buffer Helium Supply System . 4-8

4.3.4 Nitrogen System 4-8

4.3.5 Vacuum System 4-9 
4.3.6 Compressed Air System 4-9

4.3.7 High Purity Water System 4-9

4.3.8 Cooling Water System $4-10$

4.3.9 Electrical Power System 4-10

4.3.10 Circulator Transporter 4-14

4.4 Main Building

4.4.1 Space Utilization $\quad 4-14$

4.4.2 Modifications \& Additions to Existing Structures 4-17

4.4.3 Control Room 4-17

4.4.4 Heating, Ventilating and A1r Conditioning 4-18

4.4.5 Fire Protection 4 4-19

4.4.6 Plumbing 4-21

4.4.7 Communications $\quad 4-22$

4.4.8 Lighting . 4-22

4.5. Site

4.5.1 Location 4-23

4.5.2 Arrangement 4-23

4.5.3 Physical Improvements \& Demolition - 4-24

4.5.4 Acoustics $4-24$

4.5.5 Environmental Impact Assessment 4-24

4.6 Utilities

$\begin{array}{llr}4.6 .1 & \text { Electrical } & 4-26 \\ 4.6 .2 & \text { Water } & 4-28 \\ 4.6 .3 & \text { Aqueous Waste Disposal } & 4-28 \\ 4.6 .4 & \text { Telephone } & 4-29\end{array}$

5 SAFETY EVALUATION

5.1 Fire Protection and Risk Evaluation 5-1

5.2 Explosion and High Pressure Protection 5-1

5.3 Industrial Safety $5-2$

5.4 Seismic Protection $5-3$

5.5 Radiation and. Heavy Metal Safety $5-3$

5.6 Industrial Hyglene $5-3$

$\begin{array}{llr}5.7 & \text { Flood Hazards } & 5-4\end{array}$

6 SCHEDULE

6.1 Engineering $\quad 6-1$

6.2 Procurement $\quad 6-2$

6.3 Construction and Construction Inspection 6-2 
7. COST ESTIMATE

7.1 Organization and Basis 7-1

7.2 Project Cost Summary 7-2

7.3 Transportation 7-4

7.4 Utilization of Existing Equipment 7-4

7.5 Demolition and Removal of Equipment 7-5

7.6 Related Operating Expense Funded Costs 7-5

8 DRAWINGS

8.1 Test Hardware 8-1

8.2 Facility 8-8

9 OUTLINE SPECIFICATIONS

Table of Contents 9-i

Introduction. $9-1$.

9.1 Division 1 - General Requirements , . 9-1

9.2. Division 2 - Site Work 9-1

9.3 Division 3 - Concrete 9-2

9.4 Division 4 - Masonry. 9-2

9.5 Division 5 - Metals 9-2

9.6 Division 6 - Wood and Plastics 9-3

9.7 Division 7 - Thermal and Moisture Protection 9-3

9.8 Division 8 - Doors and Windows 9-3

9.9 Division 9 - Finishes 9-4

9.10 Division 10- Specialities 9-5.

9.11 Division 11- Equipment 9-6

9.12 Division 12- Furnishings $9-11$

9.13 Division 13- Special Construction 9-11

9.14 Division 14- Conveying Systems 9-13

9.15 Divislun 15- Mechanical 9-13

9.16 Division 16- Electrical \& Instrumentat1on \& Control 9-25

10 COST ESTIMATE FOR NEW HELIUM CIRCULATOR TEST FACILITY

10.1 Introduction 10-1

10.2 Basis of Design and Estimate . . 10-2

10.3 Project Cost Surmary 10-2 
SECTION 1 PURPOSE 


\section{SECTION 1}

\section{PUR POSE}

The purpose of this document is to summarize and set forth the design and estimated cost for a Gas Cooled Fast Breeder Reactor Helium Circulator Test Facility constructed within an existing but modified High Temperature Gas Reactor Helium Circulator Test Facilty.

The purpose of this modified facility is to provide the equipment, support functions and services necessary to permit full scale testing of the helium circulator and associated components for the Gas Cooled Fast Breeder Reactor Demonstration Power Plant. 


\section{SECTION 2 PROJECT SCOPE}




\title{
SECTION 2
}

\author{
PROJECT SCOPE
}

\section{$2.1 \quad$ INTRODUCTION}

Implementation of the national objective for the development of energy sources makes it imperative that the Gas-Cooled Fast Breeder Reactor (GCFR) be developed as an alternative source of power. Design studies have been underway since 1963 under contract to the Department of Energy (DOE) and a utility group. The current program calls for the completion of degign and construction of a demonstration plant by 1991 .

One of the highest priorities in the GCFR program is the testing of the circulators, the circulator drive motors, the motor controllers, the circulator diffuser and the loop isolation valve at the same power, speed, pressure, temperature and flow conditions intended in the demonstration plant. This high priority is based on the dual function operation of the circulators in the GCFR. The helium circulators not only provide the necessary flow requirements for the reactor when it is at 100 percent power, but they also provide residual heat removal following normal, off-normal and accident conditions resulting in reactor shutdown.

A progressive development program has been planned for the circulator, the circulator drive motors and controllers, the circulator service system, the circulator diffuser and the loop isolation valve. The culmination of this program is the integrated fuli-scale development, qualification and acceptance testing of these components in the GCFR Helium Circulator Test Facility described in this report. This facility must be avallable in FY- 84 in order to support full power demonstration of the GCFR by 1991 .

This work reflects a continuation of previous conceptual design work for a frFR. Helium Circulator Test Facility as reported in GA-A15300 "Update Design for a Helium Circulator Test Facility", by General Atomic Company and The Ralph M. Parsons Conpany, Apr 11 1979. The reason for this design update was the desire to reduce the facility cost by modifying an existing facility and the need to accommodate changes to test hardware concepts and ratings.

\subsection{TEST PROGRAM OVERVIEW}

Tests will be required to evaluate the performance of the prototype helium circulator, the diffuser, tlie maln circulator motor, the pony motor, the motor controllers, the circulator service module, the isolation valve, the thermal barrier and a variety of assoclated instrumentation. These components will be subjected to a development test program to demonstrate that the performance requirements for all normal and emergency conditions will be met. The test program will also include the qualification and acceptance testing required for the prototype circulator. Uniy acceptance testing will be carried out on each production unit and this will not be considered a part of the development testing. 


\subsubsection{DEVELOPMENT TESTING}

Inftial tests will be conducted on the service system at a low or ambient test vessel pressure to check out the operation of the subsystems and to demonstrate abnormal reactor operating conditions. Tests will also be conducted to obtain operating information for the circulator service module, bearings, shaft brake and jet pump. Tests will be conducted to establish performance characteristics of the bearing water system during transient conditions, performance of the varlous sealing systems, and performance characteristics of the back-up bearing water booster pump and bearing water bypass piping required for circulator coastdown.

The circulator, its drive motor and controller, and its service and control system will be tested under conditions meeting the minimum requirements for reduced operating speed and temperature conditions associated with reactor operation. The clrculator development testing will encompass the following:

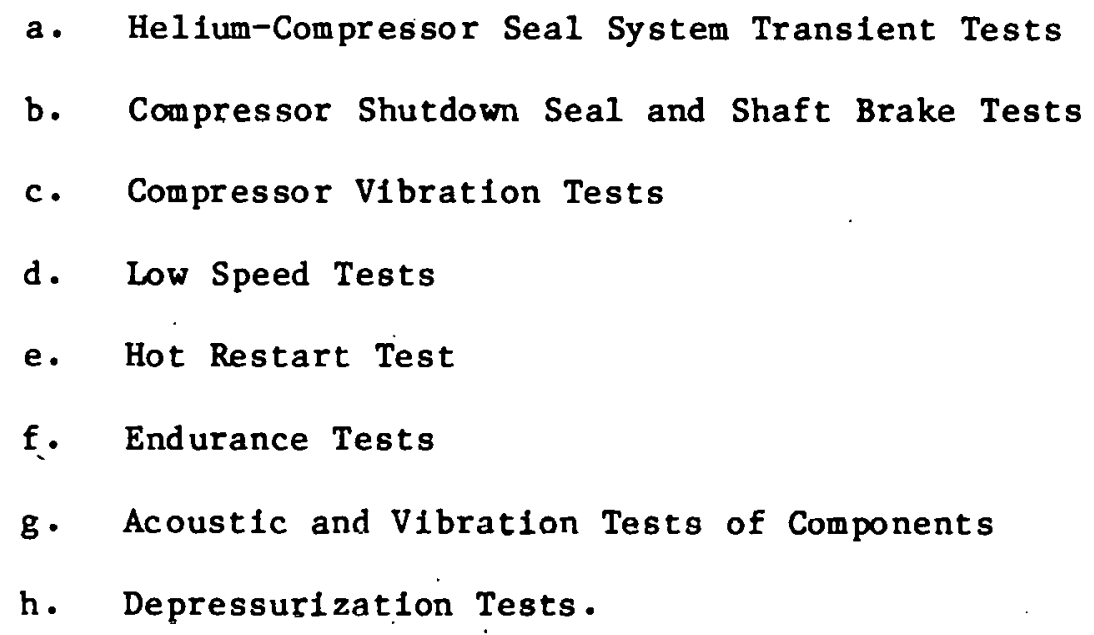

Development tests will also be performed on the 1 solation valve and the thermal barrier.

\subsubsection{QUALIFICATION TESTING}

operations:

The circulator qualification testing will include the following

a. Start rotation, uaximum acceleration at $300 \mathrm{rpm} / \mathrm{m} 1 \mathrm{n}$. Rotational speed determined by helium heat up rate.

b. Helium warm up at $100^{\circ} \mathrm{F} / \mathrm{hr}$ up to design temperature $600^{\circ} \mathrm{F}$.

c. Set speed to $1000 \mathrm{rpm}$ at $300 \mathrm{rpm} / \mathrm{m} 1 \mathrm{n}$; record data to generate compressor performance maps.

d. Repeat step "c" in $500 \mathrm{rpm}$ increments to $3000 \mathrm{rpm}$. 
e. Maintain speed (3000 rpm) and temperature $600^{\circ} \mathrm{F}$ for 24 hours .

f. Ten cycles of the following operations:

(1) Statt from no rotation;

(2) Accelerate for $100 \%$ load conditions at design speed;

(3) Run at $100 \%$ load for 60 minutes;

(4) Shut down.

g. Bring circulator up to speed ( $3000 \mathrm{rpm})$ at $300 \mathrm{rpm} / \mathrm{min}$ with helium temperature at $595^{\circ} \mathrm{F}$ and pressure at 1450 psia. Hold for 60 minutes and then shut down power supply. Speed will be reduced to zero and procedure will be repeated unt 11200 hours of operating time have been accumulated.

\subsubsection{ACCEPTANCE TESTING}

Acceptance tests w11 be carried out for prototype and production circulators. The tests will include those tests discussed under Qualification Testing, with the exception of the endurance test. Data will be continuously recorded and the time sequence of all data will be synchronized by a time code for reference. Instrumentation will be calibrated before and after testing. The qualification test procedure and test report will be in accordance with applicable quality assurance manuals.

\subsection{ORGANIZATION RESPONSIBILITIES}

The dcsigu and construction of the GCFR circulator test facility will require the cooperative efforts of several different companies and organizations. Among these are General Atomlc Company, an archltect engineer, a construction company, numerous component vendors, Helium Breeder Associates and the Department of Energy.

DOE and Hellum Breeder Assoclates will be involved because of their responsibilities as GCFR program managers. It is expected that both of these organizations would be involved in the selection of the architect engineer and the construction contractor.

General Atomic Company responsibilities will include establishment of facllity functional design criteria, selection of the architect engineer and construction contractor, procurement of major facility hardware such as the test $100 p$ vessel and piping and power distribution equipment, test article design and procurement, test support instrumentation design and procurement and post construction facility inspection and acceptance.

After completion of construction General Atomic Company will also be responsible for operator training, facility checkout and facility operation.

The architect/engineer will be responsible for the design of the facility including bullding modifications, test loop system, and process and 
control instrumentation. The architect/engineer will also be involved in the selection of the construction contractor, the monitoring of construction progress, construction inspection, and facility systems checkout.

The construction contractor will be responsible for the modification of the facility and surrounding area needed for the switchyard and other subsystems. He will also be responsible for installation of all piping, wiring, equipment, circulator and motors.

A more detailed definition of the project organizational responsibilities will be described in a Project Management Manual which will be written prior to the start of Title I design.

\subsection{FACILITY OVERVIEW}

The test facility, the major parameters of which are presented in Table 2.1 , will be housed in the existing HTGR building at GAC in San Diego, California. This building is a single-storied high bay rectangular steel framed structure with corrugated asbestos cement siding and a shallow pitched insulated roof deck. The building will be modified as required to accommodate the new system and test equipment.

The testing loop, shown schematically on the Helium Loop and Auxiliary systems Piping and Instrument Drawing No. ME-103, will consist of a circulator and its diffuser, the main circulator motor, pony motor and the test vessel with internal flow ducting and isolation valve, the large diameter piping loop which incorporates a restrictor valve (control valve) and a heat exchanger, and the rapld depressurization valve and blow down line.

The circulator test vessel, shown on Drawing ME-101, w111 be divided into two compartments. The circulator w111 be mounted in the outlet compartment end. The circulator, driven by a variable speed main motor, will discharge helium through a diffuser into the outlet compartment, and then into piping where the flow will be controlled by the use of a restrictor valve. The energy imparted to the helium by the circulator will be transferred to the Dowtherm coolant in the heat exchanger. The cooled helium will then flow to the inlet compartment where it will pass through internal flow ducting to the main circulator to complete the loop.

The Dowtherm coolant w1ll transport the energy received in the heat exchanger to an outdoor air cooler where it will be dissipated to the atmosphere.

Cooling water for the main motor, motor controllers, circulator service module, compressors and other equipment will be circulated through an outdoor cooling water/air heat exchanger, which will dissipate the waste heat to the atmosphere. The pumps for the Dowtherm coolant and the cooling water system pumps and the Dowtherm coolant storage tanks will be located outdoors on the north and west sides of the building.

Electric power for the facility will be provided from the local electric ut111ty's $138 \mathrm{kV}$ transmission system. The $138 \mathrm{kV}$ will be stepped 
down to $6.9 \mathrm{kV}$ at the facility's main power transformer. The $6.9 \mathrm{kV}$ will be distributed through the facility distribution system to the main motor controller and to the load center transformers. The main motor controller will rectify and invert the $6.9 \mathrm{kV}$ so as to provide $6.9 \mathrm{kV}$ varlable frequency power to the main circulator motor. The load center transformer will reduce the voltage to 480 volts for other facility electric power needs.

The hellum for the loop and the nitrogen used for inerting the loop will be stored in high pressure bottles outside the building.

Other systems used in the facllity will include a vacuum system, a compressed air system, a high purity water system and a buffer helium system.

The existing buliding services will be used by modifying and/or replacing parts as needed to make the systems serviceable.

The existing parking area will be modified, and unimproved areas will be graded and paved for a driveway to the service yard and for installation of new equipment. 
TABLE 2.1

FACILITY OVERVIEW

1. Helium Loop Design Conditions

Fluid

Design Pressure \& temperature, PSIG $/{ }^{\circ} \mathrm{F}$

Helium

Operating Pressure \& temperature, PSIG $/{ }^{\circ} \mathrm{F}$

$1635 / 650$

Maximum flow, $1 \mathrm{bs} / \mathrm{sec}$

$1435 / 575$

Pressure drop at maximum flow, PSI

1393

23.6

2. Test Vessel and Loop

Diameter; length \& wall thickness, FT Head opening, FT

$11.25 \times 30.08 \times 0.507$

Weight, LBS

Loop piping inside diameter, FT

5.92

570,000

4.0 to 4.17

3. Electrical Power

Commercial supply, KV

Main power transformer

Type

Voltages, KV

Rating

Primary, MVA OA/FA

Secondaries, MVA OA/FA

Load center transformers (2)

Type

138

Outdoor, oil immersed 3 phase, 3

winding

$138 / 6.9 / 6.9$

$30 / 39.9$

$15 / 20$

Outdoor, oil immersed 3 phase, 3

winding

Voltages, KV

$6.9 / 0.48$

Rating, KVA

DC system

$1000 / 1150$

Voltage, $V$

125

Rating, Ampere Hours

60.0

4. Building

Gross floor space, $\mathrm{Ft}^{2}$

Ground floor, ft 2

11,875

Basement and sub-basement, $f t^{2}$

8364

Mezzanine, $\mathrm{ft}^{2}$

1945

1566

New receiving door, $W \times H$, ft.

Test bay traveling bridge crane, tons

$16.0 \times 18.0$

Clearance, ft., approximate

15

19.5

Equipment room monorail, tons

clcarance, ft., approximate 
TABLE 2.1

\section{FACILITY OVERVIEW (Contd)}

5. Gas Storage and Supply

Helium, cubic ft/psig

$2120 / 3000$

Nitrogen, cublc ft/psig

$420 / 2400$

6. Dowtherm G Cooling System Heat Removal, BTU/HR

$79.0 \times 10^{6}$

7. Cooling Water System Heat Remova1, BTU/HR

$10.0 \times 10^{6}$

8. Demineralized Water System Storage, gal.

1000

9. Compressed Air, ACFM/PSIG

$100 / 125$

10. Vacuum System, ACFM/mm Hg Abs

$43.5 / 1$ 
SECTION 3

DESIGN REQUIREMENTS

\subsection{TEST AND SUPPORT SYSTEMS PERFORMANCE REQUIREMENTS}

This section discusses the design and performance requirements for the test systems and the immediately supporting subsystems.

\subsubsection{ELECTRIC POWER}

Electric power will be required for the main helium circulator motor, the pony motor, support auxiliaries and facility services.

\subsubsection{Main Helium Circulator Motor}

The main helium circulator motor will be powered from two identical thyristor/inverter motor controllers for variable speed control. These controllers require separate three phase, 60 hertz, $6.9 \mathrm{kV}$ sources of a combined rating sufficient to drive the circulator to $15 \%$ overspeed under full pressure and temperature conditions. At its rated speed of $3000 \mathrm{rpm}$ the circulator will have a power requirement of $30,000 \mathrm{HP}$. The motor will be a conventional totally enclosed three phase synchronous motor. The motor controller will have an efficiency of $97 \%$. Upon startup the motor inrush current will not exceed $150 \%$ of full load current.

\subsubsection{Pony Motor Requirements}

The pony motor will be a 350 HP induction motor powered from a single thyristor/inverter motor controller for variable speed control. The controller requires three phase, 60 hertz, 480 volt power. The controller efficiency will be approximately $97 \%$.

\subsubsection{CIRCULATOR TEST VESSEL}

The test vessel, as shown on Figure 3.1 , shall be a horizontal pressure vessel, made of carbon steel. It shall be constructed to allow the circulator to be mounted by means of a bolted flange joint with two concentric 0-ring closure seals.

The flange joint shall be constructed to exhibit the same stiffness characteristics as provided in the demonstration plant.

A thermal barrier made of special high temperature thermal insulation materials shall be attached inside the vessel outlet compartment by means of studs welded to the wall. It shall be a prototype of the insulation to be used on the walls of the concrete surrounded metal lined gas passageways in the demonstration power plant. 
The vessel shall be designed and fabricated in accordance with the American Society of Mechanical Engineers' Boller and Pressure Vessel Code, Section VIII, Division 1, and be designed for the following operating conditions :

Normal operating pressure Design pressure range Normal operating temperature Maximum design temperature Rellef pressure

\author{
1435 psig \\ vacuum to 1635 psig \\ $575^{\circ} \mathrm{F}$ \\ $650^{\circ} \mathrm{F}$ \\ 1635 psig
}

\subsubsection{CIRCULATOR HELIUM LOOP PIPING}

A large diameter flow loop, external to the circulator test vessel, will be required to provide a circulation path for the helium from the vessel. This loop must accomodate a restrictor control valve, a helium/Dowtherm $G$ heat exchanger, connections for the rapid depressurization blow down line and provisions for a future addition to the loop.

The pressure drop characteristics of the helium loop must be such as to permit a flow of at least $1393 \mathrm{lb} / \mathrm{sec}$ of helium, at a pressure of $1435 \mathrm{psig}$ and a temperature of $575^{\circ} \mathrm{F}$, with a total pressure drop external to the vessel of no more than $23.6 \mathrm{psi}$. A throttling valve (restrictor valve) must be provided to permit helium flow control over the range of at least 0-393 lbs/sec. The valve position must be remotely controlled from the control room. The valve control system must include a valve position ind Ica tor.

Acoustic measurements will be made at the following flows and differential pressures:

Mass Flow
$1 \mathrm{bm} / \mathrm{sec}$.

a) 1028

b) 1180

c) 1393
$\Delta P$

$\underline{\text { ps1 }}$

32.4

29.2

23.6

The helium/Dowtherm $G$ heat exchanger shall be required to remove $2.25 \mathrm{MW}$ to $22.5 \mathrm{MW}$ thermal energy $\left(7.9 \mathrm{X} 10^{6} \mathrm{BTU}\right.$ 's per hour to $79 \mathrm{X}$ $10^{6}$ BTU's per hour) from the helium. The Dowtherm $G$ temperature and/or flow shall be controlled as required to maintain a heat exchanger helium outlet temperature of $\pm 5^{\circ} \mathrm{F}$ over the temperature range of $120-600^{\circ} \mathrm{F}$.

All piping and pressure boundary components attached to or installed within the helium $100 \mathrm{p}$ shall be designed and constructed in accordance with the American Society of Mechanical Engineers' Boiler and Pressure Vessel Code, Section VIII, Division 1. 


\subsubsection{HELIUM SUPPLY AND STORAGE}

Provisions shall be made to supply, store and reclaim helium. Helium will be added to or withdrawn from the helium loop by a supply and storage system. Control shall, be provided from the control room with local manual override. Helium supply shall also be required for the circulator service system.

The leakage of hellum from the hellum systems, including the test vessel, is not expected to exceed $1 \%$ of the total helium inventory per day at design pressure and temperature.

\subsubsection{BUFFER HELIUM SUPPLY SYSTEM}

Buffered helium supply of 12 acfm shall be required for the circulator service module at approximately 15 psi above the test vessel pressure. Since 7 acfm shall be returned from the service module, a make-up of 5 acfm shall be required from the hellum supply system.

\section{1 .6 COMPRESSED AIR SYSTEM}

Compressed air at 100 psig shall be required for instruments and controls, pneumatic tools, cleaning equipment, and miscellaneous maintenance purposes.

\subsubsection{HIGH PURITY WATER SYSTEM}

A high purity water system shall be required to supply water to the circulator service system for use as the circulator bearing lubricant. For normal operation, $5 \mathrm{gpm}$ of makeup demineralized water shall be required intermittently from a water storage tank. Supply pressure to the system shall not be less than 20 psia.

\subsubsection{COOLING WATER}

Cooling water shall be required for the main motor, main motor controller, clrculator service module, helium compresser package, air compresser, and buffer helium cooler. Cooling water requirements shall be as follows :

\section{I tem}

Circulator motor cooler

Circulator service module cooler

Helium Compressor cooler

Buffer hellum cooler

Alr compresser cooler

Main motor controller cooler

\section{F 1ow (GPM)}

830

170

20

30

20

40
Heat Duty (BTU/hr)

$5,300,000$

$1,200,000$

200,000

300,000

700,000

200,000 


\subsubsection{VACUUM SYSTEM}

A vacuum system shall be required to attain an absolute pressure of less than $1 \mathrm{~mm}$ of $\mathrm{Hg}$. within 8 hours. This shall be used to purge and dryout the helium loop before filling with helium.

\section{$3.1 \cdot 10$ NITROGEN SYSTEM}

Nitrogen shall be required for inerting the helium loop after shutdown. It shall also be needed as a cover gas for the demineralized water supply and the Dowtherm $G$ storage tank.

\subsubsection{INSTRUMENTATION}

Instrumentation and controls for monitoring and controlling the test and facllity equipment shall be required in the control room, including a data acquisition system with various recorders and readout devices.

\subsubsection{HELIUM RAPID DEPRESSURIZATION SYSTEM}

The Helium Rapid Depressurization System shall have a controllable opening rate, fast acting valve connected to the circulator vessel discharge line upstream of the restrictor valve. The helium loop safety valves shall be connected to the same line. They shall both be piped to a blowdown line which shall discharge to atmosphere. The rapid depressurization requirement shall permit a rapid pressure reduction in the testing loop from 1485 psia to 34.8 psia in 201.2 seconds.

\subsubsection{CIRCULATOR REPLACEMENT}

Provisions shall be made to allow for the replacement of the circulator after testing has taken place. This shall require that the main motor along with the pony motor be moved away from the test vessel to enable the circulator transporter access to support and remove the tested circulator and to replace it with the new circulator to be tested.

\subsubsection{CIRCULATOR SERVICE MODULE LOCATION}

The center line of the circulator service module shall be below the center line of the circulator, and no low point traps shall be permitted in the piping between the circulator service module and the connections on the circulator.

\subsubsection{PROVISIONS FOR FUTURE TESTING}

A space not less than 35 feet high 30 feet wide and 30 feet long shall be provided for future testing. The design shall not prevent access from the helium loop flanges to this space. 


\subsubsection{NOISE LIMITATION}

The circulator noise level in hellum is expected to be $160 \mathrm{db}$ at maximum operating conditions. The nolse level of the main circulator motor three feet outside of the motor casing will be no greater than $95 \mathrm{db}$.

- To prevent interference with acoust1c measurements of the c1rculator, the restrictor valve shall not emit more than 3.5 Watts of acoustic energy in any octave band in the range of $63-8000 \mathrm{~Hz}$.

- Personnel nolse exposure, for 8 hour occupancy in the test bay, shall not be greater than $85 \mathrm{db}$. The use of ear protectors is permissible.

- Nolse at the property boundary due to this facility shall be no more than $65 \mathrm{db}$ during daytime ( $7 \mathrm{a} . \mathrm{m}$. to $7 \mathrm{p} \cdot \mathrm{m} \cdot$ ) or $60 \mathrm{db}$ at night.

\subsection{FACILITY REQUIREMENTS}

Th1s section discusses the design basis for the facility which supports the test systems and subsystems and accommodates personnel. A few of the codes or standards are sufficlently broadly applicable to most of the facility design that are listed here. Others of a more specific nature are included in the Individual sections that follow, as applicable.

- ERDA Manual Append1x 6301, "General Design Criteria"

- The Untform Bullding Code (UBC)

- Occupational Safety and Health Administration (OSHA) Standards, 1976 Edition

- Callfornia Public Resources Code (Coastal Resources Planning and Management Policies)

\subsubsection{SITE}

Site work 18 all that construction external to the facility building. Applicable codes and standard shall be:

- American Soclety of Civil Englneers (ASCE) "Manual of Practice No. 37, Design and Construction of Sanitary and Storm Sewers."

- American Iron and Steel Institute (AISI) "Handbook of Steel Drainage and Highway Construction Products."

- State of California Department of Transportation "Construction Manusl." 


\subsubsection{Ground Preparation}

Excavation and grading for roadway expansion, removal of abrupt grade changes on access roads, truck turnout at the bullding truck access, parking, and area fire hydrants shall be required.

\subsubsection{Roads, Walks and Parking}

A new 13 foot driveway shall be required to the service yard on the west side of the bullding for access to equipment and the electric switchyard.

The existing paved parking area shall be modified but space will be retalned for 21 vehicles:

\subsubsection{Substation Yardwork}

Electric substation yards shall be graveled.

\subsubsection{STRUCTURAL}

\subsubsection{Codes and Standards}

- Applicable Codes and Standards to be used:

- American Concrete Institute, ACI 318-77, "Bullding Code Requirements for Reinforced Concrete."

- American Institute of Steel Construction, "Manual Steel Construction," Seventh Edition as amended .

- American National Standards Institute, ANSI A58.1-1972, "Bullding Code Requirements for Minimum Design Loads on Buildings and Other Structures."

- American Welding Soclety, AWS D1.1 "Standard Code for Welding in Buflding Construction."

\subsubsection{Design Loads}

Design loads and forces for all structures shall include dead, 11ve, wind, earthquake, impact, speclal, and miscellaneous loads, as defined below. Equipment loading shall be used, as applicable, if equipment loads including impact are greater than the minimum design live loads over the area occupied by the equipment. All supports shall be designed for the maximum live load that it is possible to put in or on the equipment. 


\section{Dead Loads (DL)}

Dead load is the vertical load due to the weight of all permanent structural and nonstructural components of a structure, such as walls, floors, roofs, piping, flxed equipment, heating, ventilating, and air conditioning systems. The vertical and lateral pressures of liquids shall al so be treated as dead loads, as provided in Section 9.2.4 of ACI 318-77.

\section{Live Load (LL)}

Live load is the load superimposed by the use and occupancy of the structure, not including seismlc load, or dead load. The following uniform live loads shall be used as minimum, in pounds per square foot of horizontal projection.

$\begin{array}{lr}\text { Roof } & 20 \mathrm{psf} \\ \text { Floor } & 100 \mathrm{spf} \\ \text { Stairs \& Walkways } & 100 \mathrm{psf} \\ \text { Office Area } & 50 \mathrm{psf}\end{array}$

\section{Wind and Tornado Load}

The design wind load shall be twenty (20) pounds per square foot of vertical projection. Tornado loads shall not be considered.

\section{Selsmic Loads}

The facility shall be designed for Zone 3 , In accordance with Chapter 23, of the Uniform Building Code.

\subsubsection{Bullding Structural}

The bullding is existing. A new floor shall be provided over most of the existing test pit. Steel supports for equipment shall be provided and floor pads and foundations shall be added where needed to support the new equipment. Structural steel shall be A36 with A325 bolts, and 3,000 psi concrete shall be used.

\subsubsection{Support Structures Outside Bullding}

Steel Supports

Structural supports shall be provided for equipment in the yard area, using A36 steel A325 bolts.

\section{Foundations}

Bearing pressure will be limited to 2000 psf on three feet of compacted backf 111 and a $33 \%$ permissible increase for load 
combinations which includes wind or seismic. Concrete reinforcement shall be A615 Grade 40, and 3,000 psi concrete shall be used.

\subsubsection{ARCHITECTURAL}

The arrangement of equipment items shall be based primarily on functional interrelationship and shall maximize space utilization of the existing building and minimize costs.

Existing womens and mens restroom and locker rooms shall remain in the same location.

A maximum of 6 operating and maintenance personnel per shift and 13 per 24 hour period are estimated for the facility.

\subsubsection{BUILDING SERVICE REQUIREMENTS}

The design requirements for building services, which includes air conditioning, heating and ventilation systems, fire protection, and plumbing shall be as follows:

\subsubsection{Codes and Standards}

applicable in the design:

The following codes and standards shall be used as

- American Society of Heating, Refrigeration and Air Conditioning Engineers (ASHRAE)

- Sheet Metal and Air Conditioning Contractors National Association (SMACNA)

- Uniform Plumbing Code, 1976 Edition

- Plumbing and Drainage Institute (PDI)

- American Soclety of Mechanical Engineers (ASME)

- American Society of Testing and Materials (ASTM)

o. American Society of Plumbing Engineers (ASPE)

- American National Standards Institute (ANSI)

- American Water Works Association (AWWA)

- Factory Mutual (FM)

- Cast Iron Soll Pipe Institute (CISP)

- Underwriters Laburatories, Inc. (UL)

- NF PA 


\section{2:4.2 Heating, Ventilation and Air Conditioning Systems}

Heating and ventilating systems shall be required

for four (4) general areas. These include the office, control room, and tollet/locker room areas; test bay area; electric and mechanical equipment room; and the basement and battery room. The control room shall be maintained at a sifhtly higher alr pressure with respect to the other areas to $11 \mathrm{~m} 1 \mathrm{t}$ intrusion of dust.

$$
\begin{aligned}
& \text { Outdoor Design Conditions } \\
& \text { Summer } \quad=83^{\circ} \mathrm{F} \mathrm{DB}, 71^{\circ} \mathrm{F} \text { W.B., } 1 \% \\
& \text { Daily range } 12^{\circ} \\
& \text { winter } \quad=42^{\circ} \mathrm{F} \\
& \text { Elevation }=100 \mathrm{Ft} \text {. above sea level }
\end{aligned}
$$

\begin{tabular}{|c|c|c|c|}
\hline HVAC Requirements Areas & Temperature & \% RH & A1r Flow Rate \\
\hline office & $\begin{array}{l}68^{\circ} \mathrm{F} \min . \\
78^{\prime} \mathrm{F} \max .\end{array}$ & $\begin{array}{l}20 \mathrm{~min} . \\
80 \mathrm{max} .\end{array}$ & $\begin{array}{l}\text { As required to main- } \\
\text { tain temp. and a } 0.10 \\
\text { inch. WG positive }\end{array}$ \\
\hline Control Room, & $\begin{array}{l}68^{\circ} \mathrm{F} \max . \\
78^{\circ} \mathrm{F} \max .\end{array}$ & $\begin{array}{l}20 \min . \\
80 \max .\end{array}$ & pressure. \\
\hline Tollet/Locker Room & $\begin{array}{l}68^{\circ} \mathrm{F} \min . \\
78^{\circ} \mathrm{F} \max .\end{array}$ & $\begin{array}{l}20 \min . \\
80 \max .\end{array}$ & $\begin{array}{l}\text { As required to main- } \\
\text { tain temp. and a } 0.10 \\
\text { Inch WG negative } \\
\text { pressure. }\end{array}$ \\
\hline $\begin{array}{l}\text { Hellum Loop, Helfum } \\
\text { Circulator Service } \\
\text { Module, Test Bay and } \\
\text { Receiving Area }\end{array}$ & $\begin{array}{l}55^{\circ} \mathrm{F} \min . \\
104^{\circ} \mathrm{F} \max \end{array}$ & N/A & $\begin{array}{l}\text { As required to main- } \\
\text { tain temp. }\end{array}$ \\
\hline $\begin{array}{l}\text { Electrical \& Mechantcal } \\
\text { Equipment Room }\end{array}$ & $\begin{array}{l}55^{\circ} \mathrm{F} \min \\
104^{\circ} \mathrm{F} \max \end{array}$ & $\mathrm{N} / \mathrm{A}$ & $\begin{array}{l}\text { As required to maln- } \\
\text { tain temp. }\end{array}$ \\
\hline $\begin{array}{l}\text { Janitor Closet and } \\
\text { Restrooms. }\end{array}$ & $55^{\circ} \mathrm{F}$ min. & $\mathrm{N} / \mathrm{A}$ & $2 \mathrm{CFM} / \mathrm{FT}^{2}$ \\
\hline Battery Room & $\begin{array}{l}55^{\circ} \mathrm{F} \min . \\
104^{\circ} \mathrm{F} \max .\end{array}$ & N/A & 5 atr changes/m1n. \\
\hline
\end{tabular}

\subsubsection{F1re Protection Systems}

be designed to:

The fire protection system within the building shall

- Detect, extinguish, limit and control fires and 
their resultant hazards and damaging effects.

Provide oufficlent capacity and capability for detecting and suppressing fires and transitting alarm to the control room.

- Provide equipment lncluding portable fire extingulshers to ald personnel in the control of incipient fires and in manual fire extinguishing.

0

Provide a wet plpe fire sprinkler system throughout the facility except the control room-office complex.

- The control room complex, consisting of the office and control room, and the motor control modules, shall be served by Halon 1301 fire suppression systems.

- A dry pipe sprinkler system shall back up the Halon system in the control room and office.

- The fire protection system design requirements are as follows:

$\begin{array}{ll}\text { Outside Temperature } & \begin{array}{l}\text { Summer } 90^{\circ} \mathrm{F} \\ \text { Winter } 40^{\circ} \mathrm{F}\end{array} \\ \text { Inside Temperature } & \text { Winter } 55^{\circ} \mathrm{F} \mathrm{min} . \\ \text { Earthquake zone } & \begin{array}{l}\text { NFPA Ea rthquake } \\ \text { Area } 3\end{array} \\ \text { Ordinary hazard (Group 2) } & \text { NFPA No. } 13\end{array}$

The wet pipe and dry pipe sprinkler systems shall be designed in accordance with the requirements. of NFPA No. 13 for Ordinary Hazard Occupancies, Group 2.

Portable fire extinguishers shall be required in accordance with the requirements of NFPA-10.

A Halon 1301 fire suppression system, at a design concentration of $81 x$ percent, shall be required in the control room complex and five percent for the motor controller modules. The fire alarm and detection system design shall be in accordance with the requirements of NFPA-12A. The fire alarm design shall be in accordance with NFPA No. 72A and 77D.

\subsubsection{Plumbing System}

- The hot and cold domestlc water system pressure shall be maintained at $40 \mathrm{psi}$. The hot water 
temperature shall be maintained at $140^{\circ} \mathrm{F}$. The sanitary system shall drain, off sanitary waste from the building.

\subsubsection{ELECTRIC SYSTEMS}

subsystems :

The electric systems shall consist of the following

Main Power

Lighting

Instrument and Control Power

Direct Current

Grounding

Raceways, Power and Control Cables

Communication and Annunciation

\subsubsection{Codes and Standards}

The following codes and standards, latest editions, will be used as applicablc in the design:

- National Electrical Code

- National Electric Manufacturers Association (NEMA). Standards

- American National Standards Institute (ANSI) Standards

- Underwriters Laboratories, Inc. (UL) for Master Labeled Lighting Protection Systems

o. State of California Division of Industrial Safety, High Voltage Electrical Safety Orders

- State of California, Division of Industrial Safety, Electrical Safety Orders

- State of California General Order No. 95

- IPECA Specification for $8 \mathrm{kv}$ and 600 volt Cross-Linked Polyethylene Insulated, Shielded Power Cables with a Polyvinyl Chloride jacket.

- IPECA Specification for Control and Instrumentation Cables, for Non-Flammable, Shielded and Non-Shielded, Single and Multi-Conductor Cables.

\subsubsection{Main Power System}

have three voltage levels.

The main power system supplying the facility shall 


\section{$138 \mathrm{kV}$ System}

This portion of the system shall transform, control and meter the power from the local utflity $138 \mathrm{kV}, 3$ phase power system to the test facilty's power distribution system. Power shall be stepped down from the transmission line voltage level to that required for the motor controller by means of $138 / 6.9 / 6.9 \mathrm{kV}, 3$ winding power transformer with a delta connected primary and two $6.9 \mathrm{kV}$ secondary windings; one connected delta and one connected wye; the transformer to be furnished with a faraday shield.

Control and metering shall be accomplished with a $138 \mathrm{kV}$ outdoor o1l c1rcult breaker with an isolating switch and with outdoor 3 phase $138 \mathrm{kV}$ metering equipment.

\section{$6.9 \mathrm{kV}$ System}

This portion of the system shall receive power from the $6.9 \mathrm{kV}$ windings of the main power transformer and shall provide power to the facility; both to the main motor and to the test facility's auxillaries.

Outdoor metalclad switchgear shall provide circuit switching, disconnection, metering and relaying. Metal enclosed bus duct shall connect the main power transformer to the motor controller switchgear, from this switchgear to the main circulator motor controller, and from the controller to the vicinity of the main circulator motor. The actual connection to the motor shall be by insulated flexible power cable.

Metal enclosed bus duct shall also connect the wye connected secondary winding of the main transformer to the $6.9 \mathrm{kV}$ fuse load break switch assembly to supply power to the test faclitty's 480 volt auxillary power system.

$7.5 \mathrm{kV}$ power cable shall connect the $6.9 \mathrm{kV}$ fused load break switch assembly to the load center transformers.

\section{Volts}

This portion of the system shall provide power for all motors, other than the main motor, and for all lower voltage needs through $6.9 \mathrm{kV}$. to 480 volt transformers.

Motors larger than 100 horsepower shall be controlled by power air circuit breakers. Lighting transformers, welding outlets, battery chargers, smaller motors and other mlscellaneous loads shall be controlled by motor starters and/or molded case circuit breakers in a motor control center. The two existing 480 volt motor control centers, Nos. MCC-1 \& MCC-2 shall be used to furnish power to various auxillaries of the test facility. They shall be supplied power from the 480 volt switchgear.

The 480 volt auxillary power shall be metered by two watthour meters, one on each bus of the 480 volt switchgear. Load connections 
shall be made with 600 volt power cables.

\subsubsection{Lighting}

The existing 1 ighting system shall be used throughout the test facilfty. It shall be energized from the 480 volt portion of the power system and additions shall be made to it to provide an adequate lighting system with convenience outlets in all equipment, control, test and maintenance areas, both indoors and outdoors.

\subsubsection{Instrumentation and Control Power}

120 volt, single phase power for the instrumentation and control circults shall be supplied from special circut breaker panels. These panels shall be furnished power from the 480 volt motor control centers through $480 / 120$ volt transformers, each with a Faraday shield.

\subsubsection{Direct Current}

A complete 125 Volt D.C. system shall be provided consisting of a station battery, battery panel, 125 volt main and distribution panel and a 3 phase 480 . Volts A.C. to 125 Volts D.C. battery charger. All D.C. panels shall be equipped with thermal magnetic circuit breakers.

\section{$3.2 \cdot 5.5 \quad$ Grounding}

A grounding system consisting of a heavy copper cable grid electrically connected to copper electrode type ground wells shall be provided within the $138 \mathrm{kV}$ substation. This grounding system shall also be connected to the existing grounding system within the test facility site.

A11 new electrical equipment shall be connected either to the existing grounding system on the new grounding system, using copper cables, cadweld and/or pressure type connectors. This shall also include the fence around the $138 \mathrm{kV}$ substation.

\subsubsection{Raceways, Power \& Control Cables}

\section{$7.5 \mathrm{KV}$ Power Cables}

A $117.5 \mathrm{KV}$ power cables shal1 meet the IPECA specifications for cross-linked polyethylene insulated shielded power cables with a polyvinylchloride jacket. They shall be installed underground in individual polyvinylchloride condults and above ground in individual galvanized steel conduits. These cables shall be installed in existing conduits, both underground and overhead, wherever possible.

\section{Volt Cables, Conduits and Raceways}

Lighting and 480 volt power cables shall be stranded copper conductors with 600 volt insulation. All tray conduit runs will have 
$30 \%$ spare capacity. The smallest 480 volt power conductor shall be No. 12 AWG. These cables shall be installed in the existing underground and overhead conduits wherever possible.

\subsubsection{Communication and Annunciation}

Public Address System

The existing public address system shall be expanded to provide audio contact from the control room to all principal equipment and operating areas, both indoors, and outdoors, including the $138 \mathrm{KV}$ substation.

\section{Telephone System}

The existing telephone system shall be expanded to provide telephone sets and telephone jacks for two-way communication between the control room and all equipment, test and maintenance areas, including the $138 \mathrm{KV}$ substation.

\section{Annunciation System}

All electrical alarm points shall be annunciated in the control room by means of a solid state annunciation system. This annunciation shall be in the form of a visual and an audible signal.

\subsubsection{INSTRUMENTATION AND CONTROL}

\subsubsection{Codes and Standards}

The design and fabrication of instruments and accessories shall comply with following codes and standards as applicable and referenced herein.

AMERICAN NATIONAL STANDARD INSTITUTE (ANSI)

\section{$\circ$}

ANSI B2.1

ANSI B16.5

$\circ$

ANSI B16.9

(in its entirety)

- ANSI B16.10

- ANSI B16.11

- ANSL BIG.2S
Pipe Threads

Steel Pipe Flanges and Flanged Fittings

Forged Steel Fittings, SocketWelding and Threaded

Face-to-Face and End-to-End Dimensions of Ferrous Valves

Forged Steel Fittings socket Welding and Threaded

Buttwe1ding Ends 


\author{
- ANSI B31.3 Petroleum Refinery P1ping, \\ Section 137 Leak Tests \\ - ANSI B41.0 Gages-Pressure (and Vacuum), \\ Indicating Type-Elastic Element \\ - ANSI C39.5 Electrical Safety Requirements \\ for Measuring and Controlling \\ Instrumentation \\ - ANSI C83.9 Panel Mounting Racks, Panels and \\ As s o 1 at ed Equ 1 pments, \\ Nomenclature and Dimensions \\ - ANSI C83.66 Preparation for Dellvery of Elec- \\ tric and Electronic Components \\ - ANSI C-1 National Electrical Code \\ INSTRUMENT SOCIETY OF AMERICA (ISA)
}

- ISA RP-3.2 Flange Mounted Sharp Edged Orifice Plates for Flow Measurement

- ISA Terminology, Dimenstons, and RP-16.1.2.3 Safety Practices for Indicating Variable Area Meters (Rotameters)

- ISA RP-18.1 Specification and Guides for the Us of Genera 1 Purpose Ann unclators

- ISA C96.1 Temperature Measurement Thermocouples

- ISA RP-59.2 Alrborne So und Measurement

\title{
3.2.6.2 Control Room
}

The bulk of the instrumentation shall be housed in the control room and connected by appropriate transmission devices to their sensors. Provision shall be made for top entry to the vertical control panels. The control room is adequate to accommodate all intended instrumentation and control devices.

\subsubsection{Control and Instrumentation Cables and Trays}

The control, instrumentation and electrical cables and pneumatic lines shall be run in appropriate cable trays. Electric and instrumentation signal cable shall run in separate trays. Spare conductors equivalent to $30 \%$ of the installed conductors will be required together with an additional $30 \%$ unused tray capacity. All cable in trays shall be UL labeled fire-resistant cable or approved equivalent. 


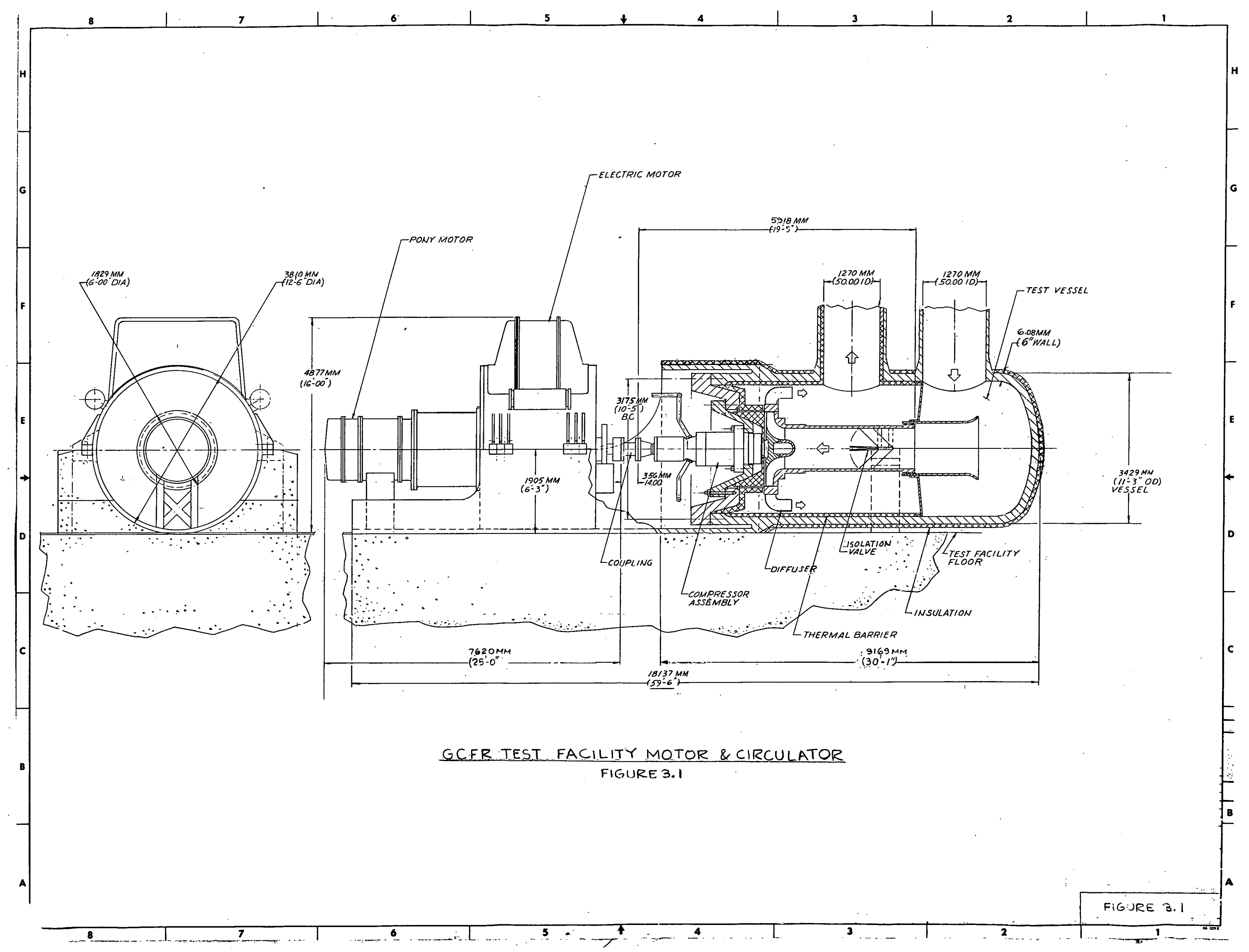


SECTION 4 PROJECT DESCRIPTION 
SECTION 4

PROJECT DESCRIPTION

This section contains descriptions of the test hardware, test and support systems, main bullding, site, and utilities.

\subsection{TEST HARDWARE}

Test hardware will consist of the helium circulator radial compressor, the circulator diffuser, the 1solation valve, the main and pony motors, the main and pony motor controllers, the main circulator service module, thermal barrier and the circulator control system.

\subsubsection{HELIUM CIRCULATOR}

The electric motor powered helium circulator will consist of a bearing assembly and radial compressor impeller as shown on Drawing 024696 . The impeller will be mounted on a horizontal shaft which will be supported by water lubricated bearings. Two radial bearings of shrouded step design will be used. This type of bearing was selected because it will provide a large hydro-dynamic lift and will be suitable for operating hydrostatically without undue complication.

Bearing water flow will cause rotation of the impeller shaft, consequently a pneumatically operated drum brake will be used to prevent the rotor from turning when the drive motor is not powered. The drum brake will be located on the shaft between the main drive motor and the compressor bearing housing, as shown on Drawing 25031, Sheet 1. The brake can be applied at up to $300 \mathrm{rpm}$.

\subsubsection{DIFFUSER}

The kinetic energy of the gas leaving the impeller will be partly converted to pressure in a diffuser consisting of thirteen conical pipes as shown on Drawing 25031, Sheet 1 . The diffuser will be installed separately from the circulator and remains in the test vessel when the circulator is removed.

\subsubsection{ISOLATION VALVE}

The GCFR main circulator isolation valve is shown on Drawing 025205. The valve will consist of two semi-elliptical flat plates supported on a common hinge joint. In the open position, the two valve plates will be nearly parallel to the centerline of the inlet duct. When closed, the plates will have rotated into a position $45^{\circ}$ to the duct centerline. The valve will be self-actuating, remaining closed at no helium flow, and will be provided with a fiber optic position indicating system. One high pressure gas jet system per valve blade provides auxiliary closing force in case a blade is hung up in the open position. 


\subsubsection{THERMAL BARRIER}

The thermal barrier will consist of multilayers of high-purity aluminasilica ceramic fiber blanket attached to the circulator test vessel wall and outlet piping with cover plates and welded attachment fixtures as shown on Drawing ME-101. The metal parts will be carbon steel, surface hardened by nitriding in the areas where sliding movement due to thermal expansion must take place.

\subsubsection{MAIN CIRCULATOR MOTOR}

The main motor will be a 30,000 HP synchronous machine rated for full power operation at $3000 \mathrm{rpm}$. The motor will be totally enclosed with a housing designed to contain missiles from any rotating motor parts. The motor air cooling system will be self-contained with an air-to-water heat exchanger within the motor housing. The bearing lubrication system will be separate from the motor. The voltage rating will be 6,900 volts at full load with starting being accomplished at zero frequency by a non-safety class, variable frequency controller.

\subsubsection{PONY MOTOR}

The pony motor will be a three phase induction motor rated at approximately $350 \mathrm{HP}$, suitable for variable speed operation over a speed range of 300 to $1500 \mathrm{rpm}$. This motor will be safety related and will be coupled to the outboard end of the main motor drive shaft.

\subsubsection{MAIN CIRCULATOR MOTOR CONTROLLER}

The adjustable frequency electric power supply consists of two parallel equally rated systems, either one of which can drive the motor. This solid state electric power supply functions in the following manner. Alternating current is supplied to each supply train from a conventional rectifier transformer. This AC power is rectified to DC and smoothed by DC reactors. The DC power is inverted into AC at a frequency selected for the desired motor speed. The normal operating range for the power supply is from an output which will provide $10 \%$ motor speed to that required for $100 \%$ motor speed. During normal operation, the commutation of the rectifier and inverter is of the "line commutated" type.

Below $10 \%$ speed, insufficient voltage is provided by the motor controller for line commutation and a different mode of operation becomes necessary for starting. For starting, the DC power is turned on and off at the frequency desired and this pulsed DC power is directed to the proper motor windings by the inverter thyristors. This results in a three-phase system of low frequency pulses being applied to the motor and permits starting and accelerating from standstill. 


\subsubsection{PONY MOTOR CONTROLLER}

The electric power for the pony motor will be from a separate solid-state controller. It will be compatible with the operating and stabllity requirements of the pony motor over its entire speed range.

\subsubsection{MAIN CIRCULATOR SERVICE MODULE}

The circulator service system will provide a closed water pumping loop that supplies the circulator with approximately $200 \mathrm{gpm}$ of high pur1ty bearing water at approximately 150 psi above test vessel pressure. All circulator fluid system components and instrumentation, including circulator brake, buffer helium and static seal actuation systems, will be located on the circulator service module. Water make-up to the service module will be from the high purity water system shown on drawing ME-104.

\subsubsection{CIRCULATOR INSTRUMENTATION}

The circulator control system, not to be confused with the motor controls or the circulator service system, will protect the machine from damage and will be prototypical of the system intended to be used in the GCFR demonstration plant. A shaft speed measurement system will be utilized to provide protection against a possible overspeed condition. A shaft displacement measurement system will prevent damage to the bearings and detect a rotor unbalanced condition. Bearing temperatures will be measured to provide a diverse method of detecting pending fallures. The performance of these systems during the operation of the test facility will contribute to design improvements in the plant circulator control system.

\subsection{TESTING LOOP}

This subsection describes those portions of the facility that will be required for testing of the hellum circulators, circulator diffuser, isolation valve, motors and controllers, and circulator service module. The test loop will consist of the helium loop and rapid depressurization system. Provision for future testing is also discussed here.

\subsubsection{HELIUM LOOP}

The helium loop will be that flow circult that will permit full hellum flow from the circulator at the design pressure and temperature. It will include the circulator test vessel, the circulator and diffuser, the internal ducting within the circulator vessel, the isolation valve, piping, the restrictor valve, the helium/Dowtherm g heat exchanger, and instrumentation and controls, as shown on ME-101, 102 and 103. The flow/pressure drop characteristics of this circuit (Figure 4-1) will be such as to enclose all of the operating points of the circulator to be tested. 


\subsubsection{Circulator Test Vesse1}

The circulator test vessel will be a large carbon steel pressure vessel which will house the helium circulator, the diffuser, the isolation valve, the inlet flow ducting, the thermal barrier and appropriate instrumentation. The vessel has been sized to provide full scale simulation of the circulator mounting configuration in the GCFR Demonstration Plant prestressed concrete reactor vessel (PCRV). The test vessel will be cylindrical in shape with one end flanged for attachment of a the circulator assembly and the other end closed with a semi-eliptical head. The interior of the vessel will be divided into inlet and outlet compartments by means of a flanged and dished head forming a partition, as shown on Drawing $M E-101$. The vessel will be 11 feet 3 inches in external dlameter with a wall thickness of 6.08 inches and w111 measure approximately 23-1/2 feet from the body flange face to the tangent line of the sem1-eliptical head. The body flange adaptor will have a 71 lnch diameter opening for insertion and attachment of the c1rculator assembly.

The interior surface of the vessel will be coated with a zinc coating material to provide rust protection. There will also be twenty-four $3 / 8$ inch and twelve $1 / 2$ inch studs welded to the interior wall of the vessel outlet compartment to support the thermal barrier. This thermal barrier will be a spectal high temperature insulation intended to be used in the PCRV of the GCFR Demonstration Plant. Its installation in the circulator vessel will be for the purpose of evaluating its effectiveness under full temperature and pressure operating conditions.

Two large nozzles of 56 inch and 50 inch inside diameters will provide for connection of supply and return piping of the hellum loop, respectively. Internal bell mouthed ducting will direct helium from the inlet compartment towards the circulator inlet. The isolation valve will be housed in a section of circulator inlet ducting which has a slip joint to allow for thermal expansion. A barrier screen in the ducting will prevent the ingestion of foreign objects into the radial compressor. Thus, the flow path of the helium $100 \mathrm{p}$ will be from the inlet nozzle, into the vessel inlet compartment through the inlet ducting, past the isolation valve, through the circulator radial compressor and the diffuser, into the vessel outlet compartment and the outlet nozzle.

A 20 inch diameter flanged manhole, located in the loop piping and an 18 inch diameter manhole located in the vessel partition, will provide for personnel entrance into the vessel for inspection and maintenance. Four instrumentation nozzles, a gas jet supply line nozzle (for isolation valve breakawa) and a drain nozzle, al1 flanged, will constitute the remaining vessel penetrations.

The vessel will be supported on the floor of the test bay by means of welded saddles.

The vessel will be designed and fabricated in acoordance with the Ameilcall Suclecy of Mechanical Englneers' Boiler and Pressure Vessel Code, Section VIII, Division 1. 


\subsubsection{Circulator Helium Loop Piping}

High pressure and high temperature helium will flow from the vessel's 56 inch diameter outlet nozzle into the helfum loop piping. The piping will be reduced to 48 inch diameter at the 48 inch restrictor valve. This valve will control the hellum flow in the loop. After the restrictor valve, the 48 inch piping will continue to the helium/Dowtherm $G$ heat exchanger via a mitered flanged 180 degree return. The discharge of the heat exchanger will be connected to 50 inch dlameter piping for return of the cooled helium back to the inlet compartment of the vessel. This will constitute the helium loop piping external to the circulator vessel.

All piping and pressure boundary components attached to or installed within the helfum loop will be designed and constructed in accordance with the American Soclety of Mechanical Engineers' Boiler and Pressure Vessel Code, Section VIII, Division 1.

\subsubsection{Helium/Dowtherm G Heat Exchanger}

The helium flowing through the hellum loop w1ll have up to $23 \mathrm{MW}$ of thermal energy imparted to it at rated operation of the circulator compressor by heat of compression and turbulence dissipation. This thermal energy will be transferred to the Dowtherm $G$ coolant in the helium/ Dowtherm $G$ heat exchanger for dissipation to the atmosphere by an outdoor Dowtherm G/air heat exchanger. The helium/Dowtherm $G$ heat exchanger will be $a$ single pass horizontal shell and tube type unit with 48 inch diameter intake and 50 inch discharge connections. The thermal rating will be 79 million $\mathrm{BTU} / \mathrm{hr}$ when passing $1,393 \mathrm{lbs} / \mathrm{sec}$ of helium flow at an inlet temperature of $588^{\circ} \mathrm{F}$. The outlet temperature of hellum will be $576^{\circ} \mathrm{F}$ when the Dowtherm $\mathrm{G}$ coolant is flowing $3450 \mathrm{GPM}$ with an inlet temperature of $300^{\circ} \mathrm{F}$. The design temperature and pressure for the tube side of the heat exchanger will be $650^{\circ} \mathrm{F}$ and $1635 \mathrm{psig}$. For the shell side, the design temperature and pressure will be $650^{\circ} \mathrm{F}$ and $150 \mathrm{psig}$.

\subsubsection{Restrictor Valve}

The helium loop restrictor valve will be a 48 inch diameter butterfly valve furnished with a. pneumatic actuator, a positioner and $a$ handweel. The function of the valve is to adjust the helium loop pressure drop to simulate various reactor system operating conditions of the demonstration plant.

\subsubsection{Helium Loop Instrumentation and Control}

Instrumentation is located in the helium loop piping to measure helium pressure, temperature and flow. Helium loop pressure and flow are recorded in the control room. High pressure is alarmed in the control room. Helium loop temperature entering and leaving the Dowtherm G/Helium heat exchanger is also recorded in the control room. High helium temperature is alarmed in the control room. 
The restrictor valve can be remotely operated from the control room, with the valve position being indicated in the control room .

\subsubsection{Acoustics}

The sound pressure within the pipe envelope as generated by the flow of helium through the restrictor valve has a negligible effect on the sound pressure level in the discharge chamber of the vessel. The calculated difference will be $50 \mathrm{dBA}$ and the variations in octave bands range between 57 and $88 \mathrm{~dB}$.

Sound pressure level in the test bay will be decreased by the application of acoustic insulation on the vessel and pipe system and acoustic absorbtive panels applied to the ceiling of the testbay. With the use of a double acoustic insulation system on the pipe and vesse 1 and 2 inches of acoustic absorbtive panel on the celling the anticipated noise level in the test bay will be $92 \mathrm{dbA}$, which is $7 \mathrm{dbA}$ above the eight hour occupancy level limit. Ear protectors can be employed to reduce personnel exposure to below the $85 \mathrm{db}$ requirement.

The sound pressure level in the control room is anticipated not to exceed $60 \mathrm{dBA}$.

\subsubsection{RAPID DEPRESSURIZATION SYSTEM}

The hellum loop rapid depressurization system, as shown on Drawing ME-103, is designed to simulate a design basis accident for the demonstration plant for the purpose of subjecting test hardware, such as the - isolation valve, to rapid pressure changes. The system will consist of an 8 inch diameter valve mounted in a blowdown line which will exhaust to atmosphere outside of the building. The valve will have a controllable opening rate to provide a helium loop depressurization condition similar to that which would occur in the reactor vessel in the event of a line break or a major leak. Different depressurization rates simulating different leak sizes will be available by adjusting the valve controller.

The system will consist of a pneumatically actuated control valve provided with a positioner and characterizing cam and the necessary electronic and pneumatic instrumentation to program the valve to allow decrease in pressure from 1485 psia to 34.8 psia in 201.2 seconds. The electronic and pneumatic hardware will be housed in a control cabinet mounted local1y. The depressurization system is designed for both local initiation and for initiation from the main control room. The instrumentation will be adjustable to permit variations in the valve opening time.

\subsubsection{PROVISIONS FOR FUTURE TESTING}

The helium piping loop between the circulator test vessel and the helium/Dowtherm heat exchanger will contain sets of flanges. By removal of the mitered return bend portion of the loop, a future testing loop may be connected into the helium loop of this facility. A space 35 feet high $x 30$ 
feet wide $x 30$ feet long will be available to the east of the test building for a future test loop.

\section{$4.3 \quad$ SUPPORT SYSTEMS}

This subsection describes those systems of the test facility that will be required to support the needs of the testing loop.

\subsubsection{DOWTHERM SYSTEM}

A Dowtherm G system, as shown on Drawing ME-103, will be provided to transfer thermal energy from the helium loop.

The Dowtherm will be pumped through the Helium/Dowtherm heat exchanger to an outdoor Dowtherm/air heat exchanger on the west side of the building. The thermal rating of the system will be 79 million BTU per hour with $3450 \mathrm{gpm}$ Dowtherm flow. The Dowtherm enters the helium cooler at $300^{\circ} \mathrm{F}$ and leaves at $400^{\circ} \mathrm{F}$. The outdoor air cooled heat exchanger will be forced draft, one bay, with two fans per bay and louvers to control the air flow over the tubes.

The system contains a 3,500 gallon tank which serves as both a storage and an expansion tank. During long periods of shutdown the Dowtherm can be transferred from the circulating loop to storage by use of the drain pump. Nitrogen will be provided to maintain an inert blanket on the Dowtherm in the storage/expansion tanks.

The temperature of the helium leaving the Dowtherm/Helium heat exchanger will be controlled automatically, with the controller located in the control room. The output of the temperature controller will modulate the 3-way control valve and the position of the heat exchanger louvers to provide temperature control. The Dowtherm circulating pumps can be operated from the control room or locally. The Dowtherm drain pump will be operated locally.

\subsubsection{HELIUM SUPPLY AND STORAGE SYSTEM}

A gaseous helium supply and storage system, as shown on Drawing ME-103, will be provided to charge the test loop and to provide storage for reclaiming helium from the loop. The system will consist of gaseous helium storage bottles, a helium compressor system including inter and after-coolers, and a dryer and associated piping valves and controls. The storage bottles will be located to the southeast of the building. The total contained volume in the bottles will be 2120 cubic feet. They will be rated for 3,500 psig with a working pressure of 3,000 psig, and will be charged with $99.99 \%$ purity industrial grade helium. 
After air evacuation, helium will be fed from storage directly to the test vessel. When the pressure difference between the bottles and the helium loop has equalized, part of the helium compressor system will be started to transfer the remainder of the helium loop charge from the storage bottles to the loop. When the pressure reaches $755 \mathrm{psig}$, filling will be stopped and the helium circulator will be started to heat the helium in the loop by compression. When the helium temperature and pressure approaches rated conditions of $575^{\circ} \mathrm{F}$ and 1,435 psia, the automatic control of the Dowtherm $G$ cooling system will then take over to control the gas temperature. Makeup helium will be added to the helium loop by the transfer pressure compressor.

Excess helium may be removed from the helium loop by use of the high pressure compressor or the depressurization valve. Helium will be transferred back to the storage bottles when the system is to be shut down. Heat generated by the compression process will be removed by the water cooled intercooler and aftercooler. The helium dryer will remove moisture to a dewpoint of $40^{\circ} \mathrm{F}$ prior to storage.

Control of the system will be local except that the transfer compressor may also be operated from the control room. Compressor package trouble will be alarmed in the control room.

\subsubsection{BUFFER HELIUM SUPPLY SYSTEM}

The buffer helium system, as shown on drawing ME-103, will receive hellum from the helium loop, cool it, compress it and supply it to the circulator service module for use at the labyrinth shaft seals of the circulator. The system will consist of a helium cooler, two helium compressors, all necessary piping and valves, instrumentation and controls.

The buffer helium compressors will supply 12 ACFM helium to the circulator service module at 1,540 psia and receive 7 ACFM at 1,400 psia. The difference will be made up from the helium loop.

The buffer helium system will be locally controlled. High hellum temperature will be alarmed in the control room.

\subsubsection{NITROGEN SYSTEM}

Nitrogen, as shown on Drawings $M E-105$, will be required for inerting the helium loop, pressurizing the high purity water storage tank, and providing an inert cover on the Dowtherm G storage tank. When the helium loop dryout has been completed by the vacuum system in preparation for a prolonged shutdown, nitrogen will be admitted to blanket the system to prevent the entrance of air. No provision will be made to recover the nitrogen.

Gaseous nitrogen will be stored in bottles adjacent to the helium bottles on the west side of the building as shown on Drawing GA-101. 
Control of this system will be local. Pressure is maintained by self-contained pressure-reducing regulator valves.

\subsubsection{VACUUM SYSTEM}

The vacuum system as shown on Drawing ME-103, will be provided to evacuate air, helium, or molsture from the Helium Loop. Before charging the loop with helium it must be evacuated in order to minimize mixing of air and helium. This will be accomplished in a period of elght hours or less to 1 $\mathrm{mm} \mathrm{Hg}$ absolute pressure. After shutdown, the vacuum system will be used to dry out the helium $100 \mathrm{p}$ of any molsture which may have entered the vessel through the water bearing seals. Control of the system will be local.

\subsubsection{COMPRESSED AIR SYSTEM}

A compressed air system, as shown on Drawing ME-105, will be provided for instruments and controls, pneumatic tools, cleaning equipment, and miscellaneous maintenance purposes. The system will be purchased as a package with all the components mounted on a skid. This will consist of two $30 \mathrm{Hp}$ compressors with assoctated coolers, an alrdryer and air receiver capable of delivering 100 SCFM of dry clean air at 125 psig. Normally, on $1 \mathrm{y}$ one compressor will be working. If necessary, both compressors can be brought up at the same time to meet a sudden surge of demand.

A dessicant type dryer will be provided to dry the air to a dew point of $40^{\circ} \mathrm{F}$. This unit will be electrically regenerated and fully automatically controlled. A recelver will also be provided to dampen the fluctuation of pressure which normally is inherent of a reciprocal compressor unit.

Control of the system will be local. Compressor trouble will be alamed in the control room. The system supply pressure will be indicated and low pressure will be alarmed in the control room.

\subsubsection{HIGH PURITY WATER SYSTEM}

High purity water will be required for lubrication of the main circulator bearings. This water will be provided to the circulator service module by the high purity water system, as shown on Drawing ME-104. Demineralized water will be stored in a $1000 \mathrm{gallon}$ storage tank located in test bay room 108. Treatment will be provided by an ammonium hydroxide injection unit for $\mathrm{pH}$ control and a hydrazine injection unit for dissolved oxygen control. The circulation pump will be operated during treatment operations to insure proper mixing. Oxygen and pH analyzers will be used to check the quality of the high purity water after treatment. Nitrogen will be used to blanket the water in the tank and provide adequate pressure for transfer to the main circulator service module.

Control of the system will be local. Low storage tank level and low system pressure will be alarmed in the control room. 


\subsubsection{COOLING WATER SYSTEM}

the following:

Cooling water, as shown on Drawing ME-104, will be provided for

1. Main circulator motor air coolers

2. Main circulator motor oil cooler

3. Circulator motor controller coolers

4. Main circulator service module coolers

5. Buffer helium cooler

6. Helium recovery compressor package coolers

7. Compressed atr aftercooler

Water will be circulated through a two bay, dry, outdoor, forced-draft, alr-cooled heat exchanger located to the north of the building. There will be two fans per bay with controllable louvers for regulating the air flow over the finned cooling colls. The cooling water cooler is designed to provide $90^{\circ} \mathrm{F}$ supply based on a summer temperature of $83^{\circ} \mathrm{F}$ dry bulb. The louvers and control valve in the water line will automatically regulate the cooling water temperature. The thermal rating of the system will be 10 million BTU/hr with $1200 \mathrm{gpm}$ of water flow. Two 100 percent capacity pumps will circulate the water through the system and an expansion tank will accommodate volumetric changes due to temperature and serve as a reservoir for makeup water.

The cooling water temperature controller will be located in the control room. The output of the temperature controller will modulate the 3-way control valve and the cooler louvers to provide temperature control. Cooling water temperature is recorded in the control room. The circulation pumps can be operated from the control room or locally.

\subsubsection{ELECTRIC POWER SYSTEM}

Four electric subsystems make up the electric power system for this facility. They are the main circulator motor power system; the auxiliary power system; the direct current system, and the control, metering and protection system. 


\subsubsection{Main Circulator Motor Power System}

The main clrculator motor will be supplied with power from the electric utility's $138 \mathrm{KV}$ transmission system through a main power transformer, switchgear, the motor controllers and interconnecting electrical cond uc tors.

The maln power transformer will step the voltage down from the transmission voltage of $138 \mathrm{KV}$ to the controller and motor level of $6.9 \mathrm{KV}$. This transformer will be located within the high voltage switchyard adjacent to the building. It will be an outdoor ofl immersed, 3 winding transformer, rated and connected as follows:

$$
\begin{aligned}
& 138 \mathrm{kV} " \mathrm{H} " \text {-Winding } 30 / 39.9 \text { MVA OA/FA - Delta Connected } \\
& 6.9 \mathrm{kV} \text { "X"-Winding } 15 / 20 \text { MVA OA/FA - Delta Connected } \\
& 6.9 \mathrm{kV} \text { "Y"-Winding } 15 / 20 \text { MVA OA/FA Wye Connected }
\end{aligned}
$$

The transformer impedances will be $\mathrm{ZHX}=\mathrm{ZHY}=10 \%$ and $\mathrm{Zxy}=20 \%$, all on a 30 MVA base. With this arrangement the equivalent reactances for this 3 winding transformer will be $\mathrm{Zh}=0$ and $\mathrm{Zx}=\mathrm{Zy}=10 \%$. This will minimize the electric interference between the two secondary windings. The transformer high voltage winding will be shielded. The neutral of the $6.9 \mathrm{kV}$ wye connected windings will be connected through an outdoor neutral grounding reactor to a switch yard grounding mat. This reactor will limit the maximum fault current during a phase-to-ground fault condition to approximately 20 percent of the fault current which would occur during a 3 phase fault, without causing an over voltage condition on the unfaulted phases. The $x O / X 1$ ratio of the $6.9 \mathrm{kV}$ system during a phase-to-ground fault will be approximately 6.5 at this location.

Metal enclosed, non-segregated phase bus duct will connect the transformer $6.9 \mathrm{kV}$ windings to the $6.9 \mathrm{kV}$ outdoor metal enclosed switchgear, also located in the switchyard. The switchgear will provide fault interruption and circuit switching for both of the $6.9 \mathrm{kV}$ circuits. The circuit breakers will be interchangeable and of the magnetic air break drawout type. The switchgear ground bus will be grounded to the existing grounding grid. Additional metal enclosed non-segregated bus duct will connect the $6.9 \mathrm{kV}$ switchgear to the motor controllers. These controllers, as described in Section 4.1.7, will convert the electric power from both $6.9 \mathrm{kV}$ windings of the transformer to direct current. The direct current will then be inverted to variable frequency $6.9 \mathrm{kV}$ alternating current for the motor supply. Non-segregated, metal enclosed bus duct will convey this variable frequency power to the immediate vicinity of the main circulator motor terminal box. Final connection to the motor will be by flexible copper cable.

The wye connected motor windings will be grounded to the existing facility grounding grid through a $15 \mathrm{kVA} 6 \mathrm{kV} / 240$ volt single phase transformer, terminated on the secondary side with a 240 volt resistor. This resistor will be sized to dissipate the capacitive KVA developed during a phase to ground fault condition within the motor windings. 


\subsubsection{Auxiliary Power System}

All facility electric power requirements other than the main circulator motor and direct current requirements (or the needs of the telephone system) will be supplied from the auxiliary power system. This auxlliary power system will take power from the wye winding of the main transformer and step it down to 480 volts through two $6.9 \mathrm{kV} / 480$ volt transformers. Outdoor metal enclosed $6.9 \mathrm{kV}$ switchgear located within the switchyard will connect the $6.9 \mathrm{kV} / 480$ volt transformer to the supply. This switchgear will contain lightning arrestors, an incoming fused load interrupter switch and two outgoing interrupter switches.

The two transformers will be oil immersed outdoor type 1000/1150 KVA "OA/FA" connected delta on the high voltage side and grounded wye on the low voltage side. Each will be a part of a separate integral metal enclosed load center capable of providing normal full facility auxiliary power requirements at its "FA" rating. Each load center will have a $6.9 \mathrm{kV} / 480$ volt dry type transformer, a ma1n 480 volt drawout type load circuit breaker, and a 480 volt bus to which 480 volt drawout type load circuit breakers will connect. One load center will contain a "tie" circuit breaker for interconnecting the load centers. This clrcult breaker will be of the same rating and interchangeable with the main circuit, breakers. The main and tie circuit breakers will have their control circuits protectively interconnected to prevent paralleling of the load center transformer on either 480 volt bus. Motors $100 \mathrm{HP}$ and electric heater loads $100 \mathrm{KW}$ and larger will be directly fed from the load centers. Smaller motors and other loads will be served from four motor control centers, located in Equipment Room 109. Instrument, 1 ighting and miscellaneous convenience 120 and 240 volt power will be supplied from small dry type transformers connected to the motor control centers.

All electric motors, all steel bullding column, transformer neutral grounding reactors and resistors and all switchgear and motor control center ground busses will be connected to the grounding grid. The high voltage switchyard steel support structures and the 1 ightning arrestors will be connected to the switchyard ground mat.

\subsubsection{Direct Current System}

The facility will be furnished with a complete 125 volt D.C. system, which will consist of a 125 volt, 60 cell, 320 ampere hour, 8 hour rating station battery, a battery panel, a battery charger, and a 125 volt D.C. distribution panel with manually operated, magnetically tripped circuit breakers. The distribution panel, a battery charger, and a 125 volt D.C. distribution panel with manually operated magnetically tripped circuit breakers will complete the D.C. system. The distribution panel provides 125 volt D.C. power to the facility's control and instrumentation, breaker closing, tripping and control, emergency lighting, and for the orderly and 
safe shutdown of the facility. The battery will be sized to handle the following loads:

\section{Operation Duration (Hrs)}

Emergency Light Load

All breaker's, for control, closing, tripping \& indicating circuits

Annunciators
4

8

8

A battery charger will supply the normal 125 volt D.C. load plus the recharge of its associated battery within 2 hours. The D.C. system is ungrounded and will be equipped with a ground detector for continuous monitoring of ground fault current.

\subsubsection{Control, Metering and Protection Systems}

All Incoming circuit breakers, including the $138 \mathrm{kV}$ oil circuit breaker (discussed in Section 4.6.1), the two $6.9 \mathrm{kV}$ air circuit breakers, the 480 volt alr circuit breakers and the 480 volt bus tie breaker will be controlled from the main control room, with a test control switch at the individual breaker. Al1 480 volt auxiliaries supplied from the 480 volt switchgear units and the majority of the auxiliaries supplied from the motor control centers will be controlled from the main control room with test control switch and/or trip switch located locally. All circuit breaker positions will be indicated both locally and in the control room.

All electric instruments and metering associated with the main drive motor will be located in the main control room. The voltmeter and voltmeter switch, indicating the voltage on each 480 volt switchgear bus, will also be located in the main control room. All other electric instruments, metering and relaying, associated with the 480 volt switchgear, will be located on the 480 volt switchgear.

The protective relays for the protection of the main transformer and for the protection of the $138 . \mathrm{kV}$ overhead 11 ne will be centralized and mounted in the main control room. All other protective relays, associated with efther the $6.9 \mathrm{kV}$ and/or 480 volt switchgear units will be mounted on hinged panels within the associated switchgear units.

Protection of electric equipment will be accomplished by means of coordinated relay systems, fuse and circuit breaker operations, thermal-magnetic overload devices and a selectlve tripping arrangement. This protection system is designed to offer maximum service dependability and minimum shutdown time due to electric disturbances. 


\subsubsection{Alarm and Annunciation System}

The operation of any electric alarm point will be annunciated locally, with a combination of these points being annunciated in the main control room under a title giving the type and location of the trouble. This will include electric equipment in the test facility, the 480 volt switchgear, the switchyard and other operating areas within the site.

\subsubsection{CIRCULATOR TRANSPORTER}

The circulator transporter will conslst of a mobil test-rig that will have the capability of supporting and centering the circulator during installation or removal from the test vessel. This will also give the circulator the capability of being moved in and out of the test facility for observation or shipment.

\subsection{BUILDING}

\subsubsection{SPACE UTILIZATION}

\subsubsection{General}

The existing HTGR-HCTF bullding was designed and constructed to house a vertically oriented vessel and associated equipment. The resultant spaces are not adequate to accomodate the horizontal vesse1/motor arrangement, intended for use in this project, without modifications.

The primary alteration consists of adding a new floor structure over part of the existing test pit, as shown on Drawing AR-101, thereby creating additional floor space for the new ground-level helium test loop. The test loop, consisting of the circulator vessel, motor, large diameter piping, restrictor valve and heat exchanger, requires floor space in excess of 60 feet by 40 feet, and add 1 tional access and clearance spaces. Such space does not presently exist in the building without bridging the pit.

\subsubsection{Interior Arrangement}

The interior arrangement of the bullding was dictated mainly by equipment and system placement (see Drawing AR-101, AR-102 and $A R-103$ ) to reduce utility runs and limit building alterations.

\subsubsection{Office/Control Room 101}

The office/control room is functionally related to the operation, monitoring and control of the testing activities being carried out in the test bay. The existing Control Room will be modified to accomodate the instrumentation and control equipment for the new system. A portion of the Control Room will be devoted to a new private office sufficient for two people. Since the control room is presently on a concrete 
slab on grade, all condults, cables, and wirling will be run overhead, above the suspended ceiling. A small trough in the floor will be cut to run conduit from the control console to other control equipment. An existing observation window in addition to glass vision panels in the pair of doors to the test bay will afford visual survelllance of the test area.

$$
\text { 4.4.1.4 Shop } 102
$$

The existing shop will provide limited in-house maintenance and repair capability.

$$
\text { 4.4.1.5 Women 104, Men } 106
$$

The existing tollets are adequate and require no

$\bmod 1 f i c a t i o n$.

\subsubsection{Recelving and Preparation Room 107}

The existing receiving area will be used for everyday deliveries of equipment and supplies to the exterior loading dock. It will serve as a temporary storage and stacking space prior to placement in other locations within the facility. No modifications are required.

\subsubsection{Equipment Room 109}

The equipment room will contain the main motor controller components, the pony motor controller, the 480 volt electrical load center, and the existing and new motor control centers, as well as the maln hellum clrculator test vessel and the 30,000 horsepower electric motor. The vessel and motor will be mounted on a new concrete slab on grade. Oil and water auxillary cooling systems for the motor will be mounted on a skid near the motor, and connections made with flexible lines and quick disconnects.

\subsubsection{Test Bay 108}

The test bay will consist of existing ground floor space adjacent to the existing pit with new floor space created by the addition of the new floor structure over the pit. The new floor space will be partially devoted to the balance of the helium loop: the large diameter piping, the restrictor valve, and the hellum/Dowtherm $G$ heat exchanger. In addition, the high purity water storage tank, the ammonium-hydroxide injection package and the hydrazine injection package will be located in the northwest corner. Equipment access to the pit below the new floor will be by a removable floor hatch. The existing 15 ton capacity bridge crane which serves this bay will remaln in service with no modifications. 
The addition of a new floor over the open test pit will transform this space into a basement. The basement will contain the balance of the test support equipment and systems as follows: Buffer Helium Compressor package, Helium Recovery Compressor package, Helium Coolers, He 11 um Dryer, Air Compressor Module, Battery Charger, Vacuum Pump, the Main Circulator Service Module, and the existing test vessel, which will remain in place. The upper portion of the test vessel will be removed to accommodate the new floor. Future removal of the vessel will not be possible without a partial demolition and removal of the new floor structure, as well as the helium loop plping and equipment above.

Two new ladders will provide egress from the basement In addition to the existing stairway. The existing ladder will be relocated due to a conflict with the hellum loop piping above. The service module ladder will provide access to the intermedlate operation and maintenance platform nine feet above the basement level. A new ladder will continue from the platform up to the ground floor level. A second new ladder will give access to the ground floor level from the basement electrical equipment area.

\subsubsection{Battery Room SB-1 and Electric Equipment Area SB-2}

The sub-basement in the northwest corner of the basement, which is at a level 13 feet lower than the basement, contains the Battery Room and Electric Equipment Area, primarily consisting of DC distribution panels. The Battery Room will contain a 3-tier battery rack. Ventilation will be exhausted to the exterior.

\subsubsection{Storage $M-1$}

The existing mezzanine space will continue to be used for storage of parts, equipment, and supplies, with the addition of adjustable shelving and storage bins. The allowable floor loading is 75 pounds per square foot. The space is protected by a metal railing on the two open sides, and is accessible by an existing metal stairway from the receiving area below and a ladder to the ground floor at the opposite end.

\subsubsection{Architectural Considerations}

The exterior appearance of the existing building will remain virtually unchanged except for the addition of a new 16 feet wide by 18 feet high rol1-up access door in the east exterior wall, in the place of an existing pair of 6 foot by 7 foot high swinging doors. The new door is necessary to provide direct access for the placement and removal of both the new test vessel and the main and pony motors, in addition to the helium circulator compressor assemblies. The existing large rolling door may not be used for this purpose due to interferences with diagonal rod bracing along column line $C$. 
While the vessel will most like 1 y remain in place throughout the program, the motor will be disengaged and removed several times to enable the removal and installation of several helium circulator compressor assemblies for testing in the vessel.

Existing steel railings on concrete curbs which are no longer necessary due to the new floor, will be removed to facilitate movement and access throughout the new test bay. New curbs and raflings will be placed around new floor openings as required.

The lower half of the existing full-height gypsum board and metal stud partition separating the existing test bay 108 and equipment room 109 will be removed to facilitate access between the two spaces. Since sound levels generated in the test vessel are transmitted by the hellum throughout the test loop, sound attenuation between the two spaces is no longer necessary. The portion of the wall above the mid-height horizontal steel strut will remain in place to act as a baffle against sound reflecting off the interior roof surface.

Two-inch thick rockwool acoustical celling panels will be installed on the entire interior roof surface to assist in achieving acoustical absorbtion characteristics necessary to reduce operational sound within the facility to acceptable levels.

\subsubsection{MODIF ICATIONS AND ADDITIONS TO EXISTING STRUCTURE}

The only true "modification" to the existing structure will involve the east exterior steel wall framing where the new 16 foot $x 18$ foot roll-up door will be installed. The existing mid-height horizontal steel strut will be ralsed to the necessary height for the new opening and the remaining steel girts and door frame will be removed and framing provided for the new opening installed.

Additional structural members associated with existing wall penetrations and accessory steel platforms will be removed.

A11 other existing structural steel members, including diagonal rod bracing will remain in place, undisturbed.

The new floor structure over the existing pit will not require any modifications to the existing structure, since the 18 inch thick concrete pit walls are more than adequate to support the new loads.

\subsubsection{FACILITY CONTROL ROOM}

Facilty control systems will involve systems which are independent of the test function of the facility or auxiliary systems which support the test functions. Facility control will be accomplished from the control room and from local control stations. 
A11 important equipment and process functions for both test and facility services will be monitored and controlled from the control room. Local control, as deemed desirable, will also be provided.

Control panels in the control room will consist of approximately twenty-two feet of eighty-four inch high vertical panels and an operator desk-type console. Functions which must be frequently monitored or controlled during operation will be displayed or controlled from the six foot facility section of the control panels. Support or less frequently monitored or controlled devices will occupy the remaining sixteen feet of vertical panels. Approximately six feet of vertical panel space will be devoted to the electric power systems, approximately six feet to test parameters and special equipnent and four feet to auxiliary and service systems.

Al1 instrument and control signals will be terminated in the control equipment cabinets located in the control room behind the control panels. Any signal conditioning devices required to translate incoming signals into signals intelligible to the control room instrument or control device will be mounted in the control equipment cabinets. Similarly, any outgolng control signal that requires translation for transmission will have its conditioning device mounted in these cabinets. This arrangement provides for orderly maintenance of instrumentation and control circuits and systems without interfering with control room personnel.

Connections from the control equipment cabinets to the instrumentation and control devices in the control panels will be routed in overhead trays and in covered concrete trenches in the floor.

\subsubsection{HEATING, VENTILATING AND AIR CONDITIONING}

The heating, ventilating and air conditioning systems (HVAC) installed in the facility will provide comfort conditions in occupied areas, provide enviroment control for equipment protection, and remove heat from the test bay area, electric and mechanical equipment room, and the basement. These systems are chown on Flow Diaglam ME=106.

\subsubsection{Office, Control Room and Shop}

An existing factory fabricated, water cooled air conditioning unit will provide filtered and conditioned air to the office and control room area via sheet metal supply and return ducts so as to maintain $68^{\circ} \mathrm{F}$ minimum and $78^{\circ} \mathrm{F}$ maximum temperatures. No humidification will be provided. Fresh air makeup will be introduced to the system for the occupants and to maintain space positive pressure within the control room at approximately 0.10 inch WG. Heating will be provided by an electric heating coil. The men's and women's toilet area, including the janitor's closet, is mechanically ventilated through sheet metal ductwork and exhausted to atmosphere by a power roof exhauster. 


\subsubsection{Battery Room}

The battery room will be heated and ventilated to maintain space temperatures of $55^{\circ} \mathrm{F}$ minimum and $104^{\circ} \mathrm{F}$ maximum. Alr will be drawn from the basement through door louvers and discharged to the atmosphere via power wall exhausters. Electric unit heaters will provide space heat.

\subsubsection{Basement}

A 4700 cfm supply fan will provide filtered air to the basement area by sheet metal ducts to remove heat dissipation from equipment. Air w1ll be relieved through the test bay areas and exhausted by the common power roof ventilators. The supply fan will be automatically controlled by a thermostat which energizes the unit when the temperature in the basement rises above $75^{\circ} \mathrm{F}$.

\subsubsection{Test Bay Areas and Equipment Room}

Filtered air through louvers will be provided to ventilate the equipment room and test bay areas and will be exhausted by a wa11 exhauster and power roof ventilators. Sound attenuation is provided in the existing outdoor air intake louvers. For air movement in these areas the wall exhauster and one of the power roof ventilators, which is located on the roof above the recelving area, will be ruming all year round. The remaining power ventilator will be automatically controlled by the room temperature, which will be set for $80^{\circ} \mathrm{F}$. No heating will be provided in these areas.

\subsubsection{FIRE PROTECTION}

\subsubsection{Genera1}

The purpose of the fire protection systems for the facility will be protection of the general public, protection of plant personnel and protection against loss of equipment. Although the combustible loading in the facility will be minimal, the potential for a fire will exist. Choosing adequate fire protection for the facility was determined by the following:

- Classification of occupancies

- Fire Hazard Analysis, type of equipment and materials

- Cost

- Codes and standards i.e., Nationa 1 Fire Protection Association (NFPA), Factory Mutual Company, and the Underwriter Laboratories. 
The Classification of Occupancles (NFPA \#13) Indicates that the facility ranges from Light Hazard to Ordinary Hazard (Group 2). Therefore, except for the control room, the facility will be protected by a wet pipe sprinkler system, which conforms to NFPA codes and standards. The control room, motor controller module and pony motor controller will be protected by a Halon 1301 system.

\subsubsection{Wet P1pe Automatic Sprinkler System}

The wet pipe sprinkler system consists of an area distributed network of water-filled pipes with upright sprinkler heads installed on pipes. The system will be actuated by the softening or melting of a fusible link in the sprinkler head. The relaxation or melting of this link will allow a tensional lever arm to unblock the flow passage, allowing water to be discharged into the fire area. In turn, the flow of water in the plping system will activate an alarm check in the main supply line, causing an alarm device (water gong) to be triggered.

\subsubsection{Halon 1301 System}

The protection of the control room will be accomplished by a total flooding Halon 1301 system. Halon 1301 , an odorless, colorless, non-toxic, non-corrosive, clean agent was chosen because of the following advantages over the other types:

- Safety to personnel

- Equipment cost

- Decreased sub-cooling of components

o Less space/weight for agent storage

- Less pressure buildup

- Better control of agent loss through uncloseable openings

Halon 1301. extinguishes fires by a chemlcal cha1n reaction and not through oxygen starvation. Following extinguishment there is no residue to clean up. The system combines highly effective detection devices with specially designed components for high speed agent discharge. It will be electrically operated and have normal design discharge time of less than ten seconds. Agent storage containers will be strategically located throughout the zone to be protected.

The motor controller modules will be protected in case of fire by a total flooding Halon 1301 system with a design concentration of 5 percent. Each cablnet section will be protected by its own system, thereby reducing the cost of installation. Each cabinet system will consist 
of a Halon 1301 cylinder and 12 feet of $1 / 2$ inch copper tubing. The Halon 1301 cylinder will be mounted on the back of the cabinet and piped to the top of the cabinet. The system will consist of the following cabinets and Halon requirements for each cabinet:

$\begin{array}{lllll}\text { Breaker } & 3.4 \text { LB Halon, } 5 \text { LB Cylinder } \\ \text { Transformer } & 1.5 \text { LB Halon, 5 LB Cylinder } \\ \text { Converter } & 5.2 \text { LB Halon, 10 LB Cylinder } \\ \text { Cooling } & 1.5 \text { LB Halon, } 5 \text { LB Cylinder } \\ \text { D. C. Reactor } & 6.7 \text { LB Halon, 10 LB Cylinder } \\ \text { Converter } & 5.2 \text { LB Halon, 10 LB Cylinder } \\ \text { Breaker } & 3.4 \text { LB Halon, } 5 \text { LB Cylinder } \\ \text { Control } & 1.8 \text { LB Halon, } 5 \text { LB Cylinder }\end{array}$

The pony motor controller will be protected by a total flooding Halon 1301 system with a design concentration of 5 percent. The system will consist of a 5 pound Halon 1301 cylinder, solenoid release, manual release, pressure switch, flexible connection and 10 feet of $1 / 2$ inch copper tubing. The Halon 1301 cylinder will be mounted on the cabinet and piped to the top of the cabinet. The Halon 1301 Fire Suppression System proposed will be designed for total flooding of the protected areas in accordance with NFPA Standard 12A.

\subsubsection{Portable Fire Extinguishers}

Portable fire extinguishers will be provided throughout the facility and will be 20 pound, dry chemical (potassium bicarbonate) type. The extinguishers will be conspicuously located so they are not likely to be blocked, hidden or damaged.

\subsubsection{PLUMB ING}

\subsubsection{General}

Water supply to the facility is provided through an existing 6 inch diameter combined fire and domestic water system, valved so that the domestic system can be shut down without impairing the supply to the fire protection sprinkler system within the facility.

An existing back flow preventor and a pressure reducing valve ensure that no contamination of the system will occur, and reduce the water pressure to $40 \mathrm{psi}$ for the plumbing fixtures.

A $1 / 2$ inch diameter pipe 1 ine is taken off the main domestic water line to the existing 20 gallon electric hot water heater located in the janitor's closet. The hot water heater will supply $140^{\circ} \mathrm{F}$ water to all lavatories, and the service sink. The men's toilet room contains one water closet, a urinal and two lavatories. The women's toilet room will contain a water closet and a lavatory complete with countertop. 
An existing water cooler for drinking is located in the aisleway outside the toilet rooms, and a service sink is installed in the janitor's closet. A sump pump located in the pit wlll periodically transfer any accumulated water to the waste 1 ine. Normal operation of the sump pump will be automatically controlled by a float switch; however a manual override will al so be provided.

\subsubsection{Sewer}

bullding to the exterior sewer line.

An existing 4 inch santtary sewer pipe connects the

\subsubsection{COMMUNICATIONS}

The existing communication system will be used with additions added as required, to provide:

- Telephone sets and public address speakers, wiring raceways, and telephone jacks for intraplant communications in all areas, including the switchyard and outlying areas, as dictated by overall facility operations.

- A public address system which includes a power amplifier, preamplifier, speakers and horns. Two types of horns, indoor and outdoor will be provided. Speakers will be used in the offices and corridor areas.

\subsubsection{LIGHTING}

The existing lighting systems will be used with additions as required to meet the minimum recommendations of the Illumination Engineering Society (IES) and to provide an adequate lighting system in all indoor and outdoor operating areas. the following:

The lighting system additions will be added in accordance with

Indoor lighting will be provided by fluorescent and mercury devices. Non-highbay areas will.utilize fluorescent and incandescent lighting with appropriate overlap for incandescent emergency coverage. Each lighting transformer will be supplied from a different 480 volt motor control center. Stairwells, doorways and closed arcao will be covered by emergency lighting. Normally, this lighting will be powered from 120 volt A.C. but will be automatically transfered to 125 volts D.C. upon A.C. power interruption.

Highbay areas will utilize mercury lighting with a small amount of emergency incandescent cover. 
Intended Principal Interior Type of Lighting and Design Lighting Levels

$\underline{\text { Area }}$

Control Room, Shop, office Test Pit, High Bay Areas

Toilets
Ilumination

$100 \mathrm{ft}$. candles

$60 \mathrm{ft}$. candles

(at floor)

$20 \mathrm{ft}$. candles
Type of Fixture

F1uorescent

Mercury Vapor or Lucalox

Incandescent

Electric convenience outlets will be provided throughout the bullding near floor level so that any floor area can be reached with a 25 foot extension cord. Outdoor lighting will be provided in all outdoor equipment areas, on all roadways and parking areas, and at all building entrances. Roadway and parking area lighting will be photo electric controlled. All other outdoor lighting will be manually controlled from the lighting panels within the building.

Intended Princlpal Exterior Type of Lighting and Design Lighting Levels

Area

Exterior Equipment Area Equipment Areas

Exterior Doorways

Roadways \& Parking Areas

\section{I11umination}

2-5 ft. candles

2-5 ft. candles

2-5 ft. candles

2-5 ft. candles

\section{Type of Fixture}

Mercury Vapor or Lucalox Mercury Vapor or Lucalox Mercury Vapor or Lucalox Mercury Vapor or Lucalox

Emergency lighting will be provided in the $138 \mathrm{kV}$ switchyard.

\subsection{SITE}

\section{4,5.1. LOCATION}

The site is located in the southwest portion of the Sorrento Valley in San Diego, California on General Atomic Company property, south of Dunhill Drive and west of the private road into the site. The existing site is for the HTGR Helium Circulator Test Facility.

\subsubsection{ARRANGEMENT}

The facility, as shown on drawing GA-101 in Section 8 , is situated on an irregular shaped plot of land, which is the present site of the HTGR Helium Circulator Test Facility. The building is located approximately 240 feet west of the private road, with the entrance to the site being approximately 560 feet from Dunhill Drive. A driveway on the south and northeast sides of the building will provide vehicular access to the building receiving entrance and to the service and parking area.

The main power transformer will be located in the fenced $138 \mathrm{kV}$ switchyard, adjacent to the northeast corner of the building, where a tie line to the local utility's nearby $138 \mathrm{kV}$ transmission line will provide powe $r$ for the facility. A nitrogen ail lielium gas bottle area will be located adjacent to the south side of the building and a cooling water/air heat 
exchanger, for facility cooling water, will be located adjacent to the service yard to the north of the building. A Dowtherm G cooler and associated equipment will be located to the west of the building.

\subsubsection{PHYSICAL IMPROVEMENTS AND DEMOLITION}

The physical improvements to the site are those things done to the land to adapt the site to the needs of the facility, other than the placement of outside equipment.

\subsubsection{Grading and Drainage}

The site will be graded to blend with existing contours, removing the existing dirt pile on the north side of the building where compacted fill will be added to support the cooling water cooler and the switchyard area.

\subsubsection{Roads and Parking}

The existing roads and parking area will be utilized without need of improvement. A new driveway will be added which will curve around the west side of the building giving access to the Dowtherm equipment and transformers, ending with a paved service yard area. A paved area for helium and nitrogen bottle storage will be added south of the parking area, with a retaining wall for the difference in elevation of the two areas. All new paving will be constructed upon compacted backfill, with six (6) inches of base course material.

\subsubsection{Demolition}

Demolition will consist of removal of parking and drive area north and west of the building and the removal of equipment foundations and guard ports to the north and west of the building.

\subsubsection{ACOUSTICS}

The sound pressure levels outdoors, as generated by the Dowtherm $G$ and cooling water coolers, will not exceed $50 \mathrm{dBA}$ at the plant boundary.

The sound pressure levels, as generated by the emergency blowdown system, will be negligible due to low magnitude and short durat1on. The nolse spectrum at the outlet pipe is dominated by high frequency noise which will be absorbed by the atmosphere and the terrain.

\subsubsection{ENVIRONMENTAL IMPACT ASSESSMENT}

The site information used in preparing the facility conceptual design and the environmental impact assessment is representative of the area in which the existing facility is located. 


\subsubsection{Description of the Proposed Action}

The proposed action is to modify an existing test faclity for developing and qualifying the GCFR helium circulators and associated equipment. This facility layout includes the following items:

1. Building with 11,875 square feet (gross)

2. Electric switchyard

3. Electric Transformer station.

4. Air cooled heat exchangers.

5. Helium and nitrogen storage

6. Driveways and parking spaces for twenty-two cars based on a maximum occupancy of 13 persons

The existing building is a rectangular steel-framed structure 102 feet long by 82 feet wide. The interior contains a single storied high bay area approximately 28 feet high and a test pit 18 feet deep with a sub-pit an additional.13 feet deep. The southwest corner of the bullding has a control room and tollet room complex. A 15 ton capacity traveling bridge crane runs the full width of the bay over the test pit, and a 12 ton capacity monorail is located over a portion of the equipment bay.

side for bullding ventilation.

Existing sound-trap louvers are located on the north

Normal building communications, electric, mechanical and fire protection systems will be provided.

Modifications to the land required for the facility will include lighting, grading, drainage, paving and landscaping to comply with the scientific research character of the area. Access is from the existing private road which serves the area.

\subsubsection{Description of the Existing Environment}

The area is basically inhabited by a large number of small businesses performing industrial type work and is currently zoned Science-Research (SR) or Manufacturing (M1-A). The majority of the surrounding area is undeveloped, with small hills and canyons. The area to the North is partly populated with businesses performing research and development. Access is provided by an Interstate Highway with offramps both at the north and south ends of the area. All the city streets located in the area are 1mproved and capable of hand1ing heavy loads.

\subsubsection{Potential Environmental Impact}

4.5.5.3.1 Construction The on 1 y adverse impact during construction will be that typical of excavation and construction. Provision will be made to mintmize air pollution through compliance with applicable Federal, state and local laws, codes and regulations. Requirements for envirnnmental pollution cullcul will be stated in the project specifications. 
Water will be used to restrict dust to tolerable levels on access roads during construction.

A facility of this size will not require an extremely large labor force nor impose any traffic problems on the area.

4.5.5.3.2 Operation Air pollution discharge from the facility will be insignificant since it is electrically powered. Very minor amounts of helium and nitrogen will leak into the air as a result of normal testing. Depressurization testing will increase the amount of helium released but without adverse effect to the environment.

Heat will be dissipated by dry type forced air heat exchangers located at the rear of the property. The anticipated sound level at the site boundaries for these heat exchangers will not exceed $50 \mathrm{dba}$.

Vehicular traffic to and from the site will be minimal. After construction, it is estimated that approximately 65 trips a week would be generated, involving 13 cars.

The personnel required to operate this facility will be partially supplied from existing and new employees. The anticipated increase of new employees will not significantly impact the existing facility or the City of San Diego.

$\underline{\text { P 1ans }}$

4.5.5.4 Coordination with Federal, State, Regional or Local

Construction and use of this facility does not conflict with any known plan or program sponsored by agencies of the Federal Government, State of California or the City of San Diego.

\subsection{UTILITIES}

4.6.1 ELECTRIC

The electric utilities will consist of the following two parts:

- The $138 \mathrm{kV}$ power line from the local electric utility's $138 \mathrm{kV}$ transmission system to the Helium Circulator. Test Facility's $138 \mathrm{kV}$ switchyard.

- The test facility's $138 \mathrm{kV}$ switchyard.

4.6.1.1 The $138 \mathrm{kV}$ Power Line

The Helium Circulator Test Facility's $138 \mathrm{kV}$ switchyard will be connected into the local electric utility's $138 \mathrm{kV}$ transmission system by means of an overhead $138 \mathrm{kV}$ power line, approximately 900 feet in length. This line will be designed and constructed in accordance 
with the State of California's General Order No. 95. It will be built using a two pole " $\mathrm{H}$ " frame construction arranged for a conductor spacing of 10 feet with two overhead ground wires and a structure spacing of approximately 350 feet. The conductor will be $300 \mathrm{mcm}$ ACSR and the ground wires will be $1 / 2$ inch diameter stranded, galvanized steel.

The connection into the electric utility's $138 \mathrm{kV}$ transmission system will be by means of an overhead, manually group operated $138 \mathrm{kV}$ load break switch and a pole structure to which the electric utility's line can be dead ended.

\subsubsection{The $138 \mathrm{kV}$ Switchyard}

Incoming power will be controlled by the facility's $138 \mathrm{kV}$ switchyard which will be arranged as shown on Drawing EE-102. The incoming $138 \mathrm{kV}$ line will terminate at an "A" frame type dead end structure from which it will be connected to a horizontally mounted $138 \mathrm{kV}$ group operated, 3 pole, vertical break disconnect switch equipped with a 3 pole, group operated grounding switch. The switch will be mounted directly under the "A" frame structure.

The incoming $138 \mathrm{kV}$ disconnect switch; $138 \mathrm{kV}$ outdoor, pad-mounted, oil circuit breaker; three outdoor, base mounted, 138 $\mathrm{kV}$ current transformers and the $138 \mathrm{kv}$ bushings of the main transformer will all be connected in series by means of overhead ACSR bare conductors and the $138 \mathrm{kV}$ strain buswork. The overhead $138 \mathrm{kV}$ strain buss will terminate at one end of the incoming " $A$ " frame dead end structure and at the other end of the main transformer's " $A$ " frame dead end structure.

The $138 \mathrm{kV}$ metering current transformer's outgoing conductor will also be connected to a horizontally mounted vertical break 138 $\mathrm{kV}$ disconnect switch ahead of the three metering potential transformers rated $80 / .12 \mathrm{kV}$ and connected in wye. These potential transformers and the current transformers will supply the revenue metering equipment, consisting of a kilowatt hour meter and a recording kilowatt demand meter. Both will be mounted in an outdoor weather-proof metering cabinet.

4.6.1.2.1 Switchyard Buses \& Major Equipment Rating A three phase fault on the $13 \overline{\mathrm{kV} \text { bus at the switchyard will produce }}$ the following fault duty and currents.

$\begin{array}{lll}\text { - } 3 \text { phase fault MVA } & 4150 \mathrm{MVA} \\ \text { ○ } & \text { RMS Symm. Amperes } & 17.4 \mathrm{kA} \\ \text { o Momentary Fault Amperes } & 27.8 \mathrm{kA}\end{array}$




\section{Equipment and Bus Ratings}

\section{Switchyard Equipment}

- Incoming $138 \mathrm{kV}$ Disc. Sw.

- Bus P.T.'s $138 \mathrm{kV} \mathrm{Disc.} \mathrm{Sw.}$

- Main Oil Circuit Bkr.

- $\quad 138 \mathrm{kV}$ Strain Buses

$\circ$

\section{$138 \mathrm{kV}$ Rigid Buses}

\begin{tabular}{l}
\begin{tabular}{l} 
Momentary Fault Ampere \\
Rat1ng at $138 \mathrm{kV}$ \\
\hline
\end{tabular} \\
\hline
\end{tabular}

$61 \mathrm{kA}$

$40 \mathrm{kA}$

$58 \mathrm{kA}$

Designed for $40 \mathrm{kA}$

Deslgned for $40 \mathrm{kA}$

Lightning Protection The switchyard equipment and the main transformer will be protected by lightning arrestors on the line side of the $138 \mathrm{kV}$ station disconnect switch. Lightning arrestors will be connected so as to ground high frequency surges and will have no sharp bends in their connections. The arrestors voltage rating will be $120 \mathrm{kV}$.

Switchyard Grounding System The switchyard will be provided with a grounding system, as indicated by Drawing No. EE-102. The system will consist of buried bare copper cable meshes and copper anode ground wells with the anodes installed below the water table's low level. The grid will extend through out the switchyard and load center transformer area and will connect to the grounding grid within the Helium Circulator Test Facility Building.

A1 1 switchyard equipment, structural steel structures, neutral grounding reactors and the switchyard fence will be connected to the grounding grid, as indicated by Drawing No. EE-102.

The details of the grounding system are described in the Outline Specification, Section 24, which includes the sizing of the anodes, connecting cables, grounding cables and type of connections.

Switchyard Communications and Lighting The switchyard will be included within the building's communication and lighting systems as outlined under paragraphs 4.4 .7 and 4.4 .8 of this report.

\subsubsection{WATER}

facility .

The existing water system will be utilized for the new

\subsubsection{AQUEOUS WASTE DISPOSAL}

facility.

The existing waste system will be utilized for the new 


\subsubsection{TELEPHONE}

facility.

The existing telephone service will be utilized for the new 


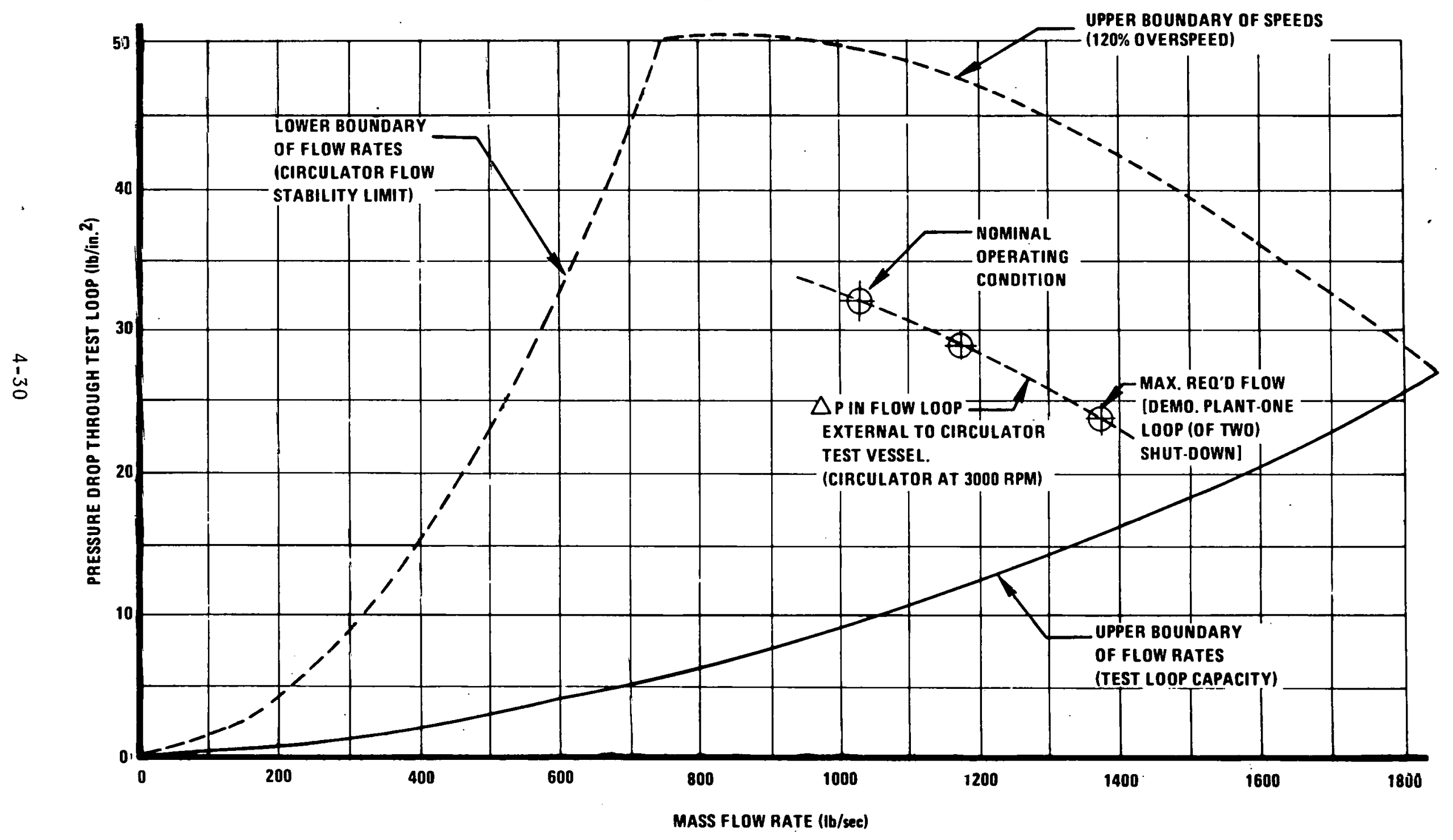

Figure 4-1 - Design Range of Flow and $\triangle P$ Conditions Pressurized Reactor Condition) 


\section{SECTION 5 \\ SAFETY EVALUATION}




\section{SECTION 5}

\section{SAFETY EVALUATION}

This section addresses personnel, equipment and structural safety aspects of the facility.

\subsection{FIRE PROTECTION AND RISK EVALUATION}

The facility building is constructed in part of structural steel and reinforced concrete, in part of concrete block and in part of insulated metal siding and roofing. The existing structure conforms to and the modifications will conform with the requirements of NFPA-101.

There are no immediately adjacent buildings or other structures. Therefore, this facility will not create a fire hazard to other facilities nor be endangered by a fire in them. The encircling roadways and paved areas will provide an effective firebreak to prevent endangering the facility from grass or ground fires.

\section{1 .1 FIRE PROTECTION}

The facility will be equipped with automatic sprinkler systems throughout except in the control room area and in the motor controllers where automatic Halon 1301 systems will be used. Portable fire extinguishers will be located in all areas for quick local attention. All of the automatic systems will alarm in the control room and at the local GAC fire station.

\section{1 .2 MOST PROBABLE FIRE INCIDENT}

The most probable cause of fire in this facility would be from insulation failure in electric equipment. The main motor controller is valued at $\$ 2,489,000$ but with the automatic fire protection systems, it is highly improbable that any fire loss would equal or exceed $\$ 100,000$.

It is believed that this facility will meet the criteria of the "Improved Risk" rating and the requirements of ERDA Manual Chapters 0552 and 6301 .

\subsection{EXPLOSION AND HIGH PRESSURE PROTECTION}

High pressure helium gas will be used in this facility at pressures up to 1635 psig in the circulator vessel, and up to 3200 psig in the helium supply and storage system. The nitrogen storage system will also be at 3200 psig, although its intended use for blanketing will be at a much lower pressure; approximately 20 psig. The vessels in all high pressure systems will be designed and fabricated in accordance with the ASME Boiler and Pressure Vessel Code, Section VIII, and the piping with ANSI B 31.1. Gas storage iylindels will cunfusu Lu the U.S. Department of 'Iransportation Title 49, Code of Federal Regulations, Transportation Parts 100-199. 


\subsection{INDUSTRIAL SAFETY}

The principal industrial safety hazards and risks that may be encountered during operation of this facility will be:

- Standard hazards associated with office space, and multi-storied large equipment test facilities.

- Standard hazards associated with movement of heavy equipment.

- Implosion and explosion hazards from high vacuum and intermediate pressure gas systems.

- Electric shock from contact with high and intermediate voltage electric systems.

- Burns from high temperature vessels and piping.

Single or dual fatalities will be the maximum probable consequences of injuries that would result from these hazards. Property damage could occur from several of them. Measures taken to prevent accidents and reduce damage and risks from these hazards are discussed below.

\subsubsection{RISKS ASSOCIATED WITH OFFICE SPACE, AND LARGE EQUIPMENT TEST FACILITIES}

These risks will be controlled by designing and modifying the facility in accordance with the requirements of ERDA Manual Appendix 6301 , and applicable national, federal and state standards, codes and regulations.

Emergency electric power w111 be provided from batteries for lighting of all stairways, hallways, ladders, exits and essential equipment areas, both indoors and outdoors.

Railings will be used for all open pit areas and stairways.

\subsubsection{RISKS ASSOCIATED WITH MOVEMENT OF HEAVY EQUIPMENT}

For installation purposes, all heavy equipment will be moved by outside contractors whose business is the moving of large and/or heavy objects. They will use licensed equipment and employ trained operators.

The transporter for the circulator will have elevation and positioning capability from a stable secure platform. The circulator will be secured on the transporter by large clamps or bolts so that there will be very limited risk of personnel injury during movement or installation of the circulator. 


\subsubsection{RISKS FROM FAILURE OF VACUUM SYSTEMS OR INTERMEDIATE PRESSURE GAS SYSTEMS}

A vacuum system will be provided for circulator vessel dryout. Intermediate pressure air systems will be provided for instrument and service air. Operations involving the use of these systems will be planned and personnel trained to ensure knowledgeable usage in compliance with engineering and operational safeguards and all governing regulations.

\subsubsection{RISKS OF ELECTRIC SHOCK FROM ELECTRIC SYSTEMS}

The electric equipment and facilities will conform to the latest edition of the National Electrical Safety Code, "Safety Rules for the Installation and Maintenance of Electric Supply and Communication Lines, ANSI C-2", to the requirements of the City of San Diego; and to the State of California Division of Industrial Safety, "High Voltage Electrical Safety Orders and Electrical Safety Orders"; and to the State of California General order No. 95. High voltage equipment will be operated only by a qualified operator, as defined in the State of California Division of Industrial Safely, "High Voltage Electrical Safcty Orders".

\subsubsection{RISK OF BURNS FROM HIGH TEMPERATURE VESSELS OF PIPING}

All high temperature piping, vessel or other equipment will either be thermally insulated so that exposed surfaces will not exceed $150^{\circ} \mathrm{F}$ or will be protected by barriers so that personnel cannot be inadvertently exposed to the risk of burns.

\subsection{SEISMIC PROTECTION}

\section{4 .1 . BUILDING STRUCTURES}

The facility structure was designed and constructed in accordance with the Uniform Building Code.

\subsubsection{MECHANICAL AND ELECTRICAL EQUIPMENT}

All large fixed equipment will be secured to its foundation so that overturning cannot occur. The building and outside structures have been designed to withstand a Uniform Building Code Zone 3, Earthquake, intact. Therefore, it is not expected that any damage to equipment or the facility structureiwill occur in the event of a design basis earthquake.

\subsection{RADIATION AND HEAVY METAL SAFETY}

There has been none and will be no radioactive materials or heavy metals handled in this facility. 


\subsection{INDUSTRIAL HYGIENE}

Dowtherm $G$ is a manufactured organic liquid with a high boiling point and a low freezing point. It has very low toxicity in either the vapor or liquid form as a result of either inhalation or ingestion. In a few cases it has caused mild skin irritation upon liquid contact. However, it has a very distinctive and usually disagreeable odor, even in low vapor concentration. The helium/Dowtherm $G$ heat exchanger and its connecting piping are all welded construction so that leakage of the Dowtherm $G$ fluid is highly unlikely. The entire Dowtherm $G$ system is a closed system. It is opened only for maintenance and for storage tank filling. Thus, the probability of spillage is small. In the event of spillage, as a result of equipment fallure, protective clothing and breathing apparatus can be employed to limit personnel exposure during repair and cleanup.

\section{$5.7 \quad$ FLOOD HAZARDS}

This facility will be out of any flood plain and will have a site drainage system adequate to handle anticipated surface $r$ unoff. All below grade structures have been treated to retard water seepage. A sump in the basement of the building will collect any liquid which accumulates as a result of leakage, spillage, or other cause, and a sump pump will pump it out of the building. There will be a negliglble chance of flooding causing damage due to liquids, to any part of this factlity. 
SECTION 6 SCHEDULE 
SECTION 6

SCHEDULE

The engineering procurement and construction schedule, Figure 6.1 , is based on the required facility acceptance and turnover date of July 1,1984 . Identifled are the time periods in which the engineering and construction must occur. The schedule also identifies major milestones and interfaces for engineering and design, procurement, installation and construction, and for operational testing.

The overall objective of the schedule is to produce an engineering and construction plan that will provide the following:

- Basis for estimating engineering and construction costs.

- Determination of the total time required for facility construction.

- Definition of the major project schedule parameters.

In order for this schedule to be met it will be necessary to fast track this project. This will mean that the normal sequence of activities, of firming up a design feature before the next step is taken, will not always take place and that there will be overlapping of activities which could result in some extra work and costs.

As explained later some equipment will have to be purchased during the Title I effort. This will require the equipment to be engineered and purchased, using some data that can only be checked at a later date, and also before Title I has been approved. Likewise, some equipment will have to be engineered and purchased in Title II under simflar circumstances.

\subsection{ENGINEERING}

Based on the start of Architect - Engineer Title I engineering and design of October 1, 1981, it is expected that Title II final design would be completed by December 1,1982 . This assumes a five month Title I activity, a one month review by the client and an eight month Title II design.

Due to the long lead time for the electric power distribution equipment, the engineering for this equipment will have to be finalized in Title I. The calculations for the test vessel and large diameter pipe will also have to be finalized in Title I allowing only the specifications to be written in Title II.

Architect-Engineering Title III services would begin five months before the start of the construction work to allow completion of the inspection plan for inclusions in the construction packages. The Title III work would take place over a period of 23 months, extending approximately one month beyond che completion of construction to permit the completion of as-built drawings and file close out. 


\subsection{PROCUREMENT}

The schedule shows that some procurement specifications will have to be issued prior to both the Title I and the Title II review.

The procurement specification that must be issued prior to approval of Title I is the electric power distribution equipment, which must be issued for bid approximately February 1, 1982. Three procurement specifications must be issued prior to approval of Title II; the test vessel which must be issued for bid approximately June 1, 1982, the large diameter piping which must be issued for bid approximately June 1, 1982, and the Dowtherm G/helium heat exchanger which must be issued for bid approximately October. $1,1982$.

\subsection{CONSTRUCTTON AND CONSTRUCTION TESTING}

If an environmental impact report is required it would need to be filed and approved before site work can be started.

It is expected that with a two month Title II review period, construction would start mid February 1983, with some site preparation, equipment removal and demolition inside the main building, followed by the renovations inside the bullding. The outside foundation work would be performed during the summertime followed by erection of the equipment. The final site development work and cleanup would then take place, completing the construction July 1, 1984.

Inspection activities will take place as the work is completed, with the systems inspection and testing taking place in the last three months prior to facility acceptance and turnover. 


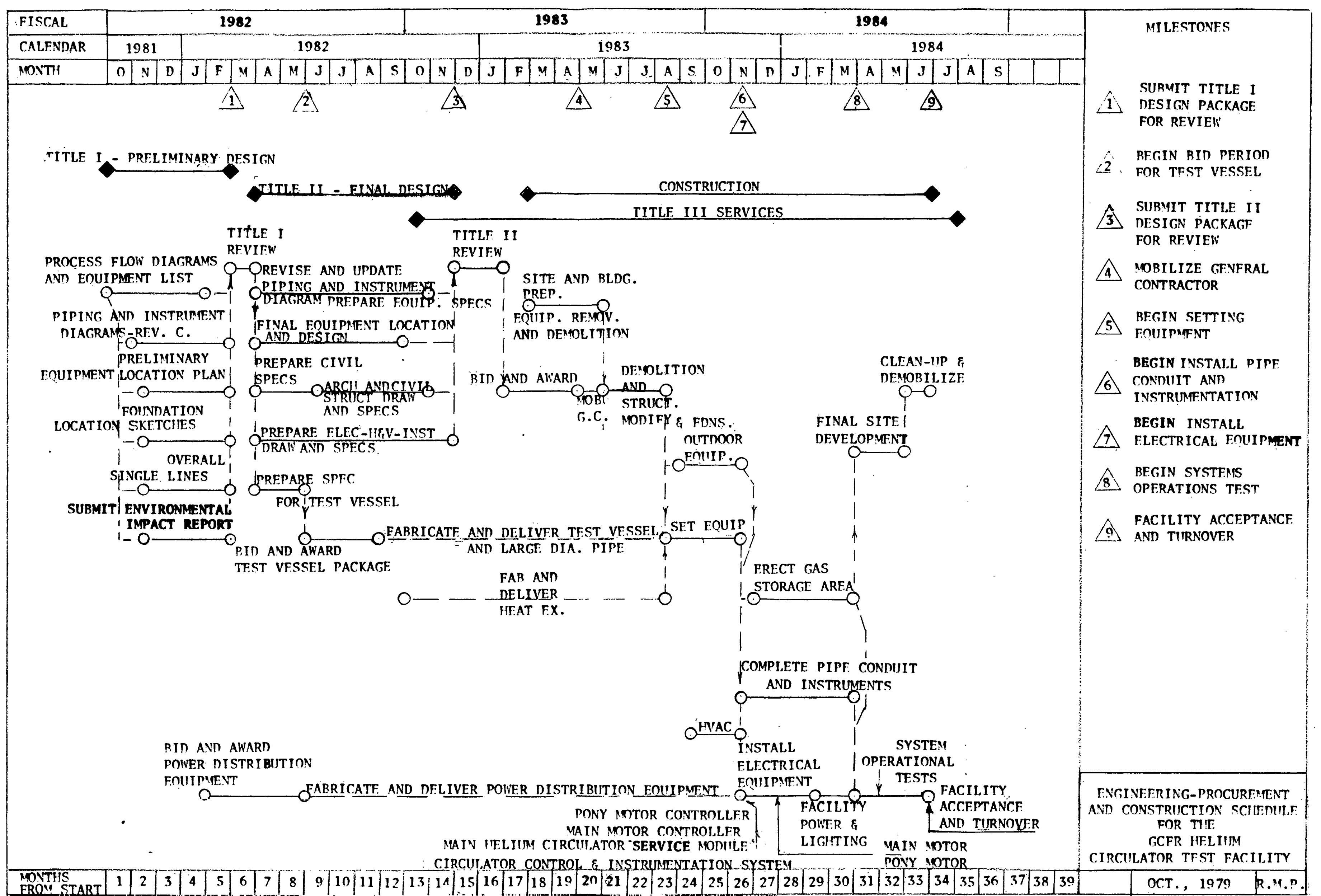


SECTION 7 COST ESTIMATE 


\section{SECTION 7}

\section{COST ESTIMATE}

This section of the report summarizes the cost estimate for the test facility. The level-of-effort of this cost estimate is compatible with the conceptual design contained in this report. The estimated costs of equipment and systems for which GAC was responsible are included herein as provided to Parsons by GAC.

\subsection{ORGANIZATION AND BASIS}

The conceptual design cost estimate as presented in this report is based on the following:

- Conceptual design drawings included in Section 8.

- Preliminary engineering and construction schedule included in Section 6 .

- Out1ine Specifications included in Section 9.

- Engineering costs are the General Atomic Company's estimates of their participation in the Title I, II and III phases of this project together with Parsons estimate of the Architect/Engineer's costs for the design of the test systems, the design for modiftcation of the HTGR facility and the inspection of construction. These $A / E$ costs were developed from a detailed task estimate of the effort required to perform the Title I, II and III engineering for the facility.

- It is assumed that this facility will be constructed by lump sum sub-contractors with a construction manager contractor under a percentage fee.

- Where possible, vendor quotations were obtained for the costs of equipment. Where quotations were not avaflable, the cost was developed on the basis of historical data pertaining to similar type equipment.

- The pricing of bulk material is based on current experience in the San Diego area.

- Shipping and hauling costs for the large circulator test vessel were based on special studies.

- Quality assurance requirements on materials, equipment, and construction are limited to those normally obtained on an industrial project. 
- Tests other than those normally provided by a construction contractor are excluded.

- Construction Management costs were based on a fixed percentage of the total construction costs, excluding eng ineering.

\subsection{PROJECT COST ESTIMATE SUMMARY}

The construction and engineering costs for the project are sumarized in Table 7-1. The format is in conformance with ERDA Appendix 1301, Part II, Section C2, entitled, "Schedule 44 Construction Project Data Sheet." Government furnished equipment is used in this table to refer to items the General Atomic Company, as the operating contractor, would procure and provide to the constructor for installation.

Cost breakdowns are provided in supplemental tables to permit cost tracing of an account from the schedule 44 format to the construction Specification Institute (CSI) Divisions, Table 7-2, 7-3 and 7-4.

- Craft labor rates are work operation composites based on labor agreements in effect for San Diego area work as of September, 1979, and include travel, fringe benefits, payrol1 taxes and insurance where applicable. Labor costs are based on straight time, standard single shift work week of 40 hours.

- Labor productivity included in the estimate reflects Parsons studies and experience for construction of this type for the San Diego area.

- The sub-contractor indirect costs are estimated under C.S.I. Division 1, General Requirements. All indirect field costs are related to estimated direct labor costs, and are a percentage of these costs based on lump sum contract experience for this type of work in the San Diego area.

- The escalation rates used for construction equipment, materials, and labor were taken from escalation tables published by INEL. With an October 1979 estimate base date, escalation percentages were compounded yearly, including the three months in 1979 and all the time up to an estimated month and year at which half of the expenditure for each activity would occur.

- The escalation rates used for engineering are by the Ralph M. Parsons Company for the $A / E$ and from the General Atomic Corporation for their participation. For A/E engineering costs, with an October, 1979 estimate base date, escalation percentages were compounded yearly including the three months in 1979 and the time up to the scheduled month and 
year at which half payment for the activity would occur. For GAC engineering costs, escalation percentages were compounded yearly based on a flat rate for each complete or partial calendar year starting January 1, 1980.

- The contingency used in the estimate represents Parsons evaluation of job scope adequacy, rellability of quotations, modification work difficulties, experience with conceptual level estimates, and execution of the engineering and construction on a fast track basis.

- The CSI coding system, developed by the Construction Specification Institute, was used to identify the estimate components.

- Electricity, water and sanitary sewer services are assumed to be available on site.

- The cost base of the estimate is October 1979. Al1 sumary costs are shown as "As Spent" dollars unless otherwise noted.

- Construction management costs are based on a percentage of the total construction costs excluding englneering.

INCLUDED IN COST ESTIMATES ARE:

estimate:

The costs for the following items have been included in this cost

- Titles I, II, and III Architect-Engineering services, including preliminary engineering, final design, and inspection services.

- Titles I, II, and III General Atomic Company services, including engineering, procurement and project management.

- Site clearing, grading, and excavation.

- Demolition of existing civil and structural facilities only to the extent required to accomodate test equipment and new support services equipment in the facility.

- Transport of the circulator test vessel from rail siding to job site.

- Furnish, renovate and install helium and nitrogen bottles.

o Bulk materials and the labor of installation.

- Mechanical and electric equipment, vessels, tanks, conduit, wire, busways, cable, heating, ventilating and air condictoning, tire protection, plumbing, painting and related items, and the labor of installation. 
- Sub-contractor's overhead and profit.

- Escalation on materials and labor to the mid-point of construction as determined from the project schedule.

- A contingency which reflects Parsons experience in developing cost estimates for this type of project and with this degree of engineering and design, plus an allowance for the inefficlencles sometimes encountered in "Fast Track" execution.

- Installation of GAC supplied equipment and materials.

GAC has developed and furnished costs for inclusion in this estimate for the following items:

o Titles I, II, and III General Atomic Company services, including engineering, procurement and project management.

- Instrumentation and Control Equipment for the:

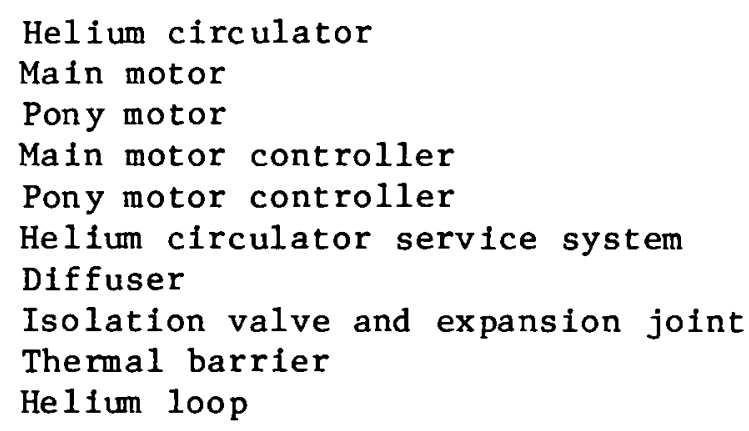

EXCLUDED FROM COST ESTIMATE ARE:

The costs for the following items have been excluded from the total estimated cost of the test facility:

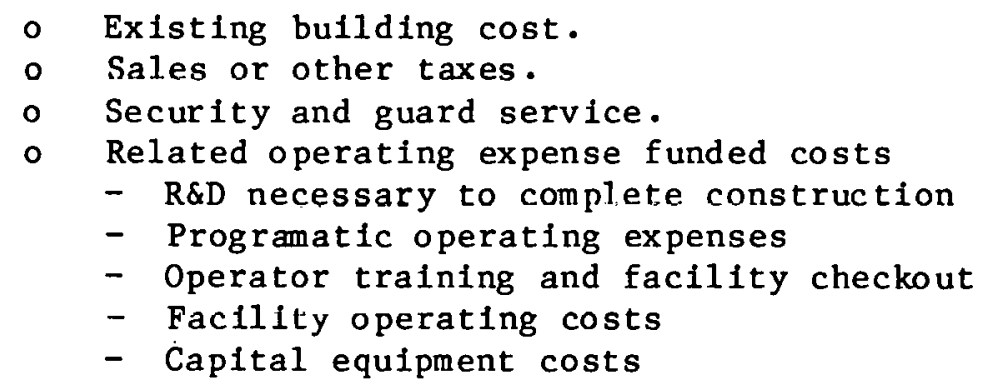

\subsection{TRANSPORTATION}

Special rafl freight arrangements will be required for shipping the 285 ton Hellum Circulator Test Vessel. Parsons in conjunction with the ra11- 
way carriers made a route and cost study which has been used in this estimate.

\subsection{UTILITIZATION OF EXISTING EQUIPMENT}

7.4.1 The high purity water system will utilize the existing 1000 gal. Bearing Water Storage Tank $(T-9)$ in a new location. The electric system will use one existing motor control center (MCC) in its present location and one existing MCC in a new location. Use of the existing bullding and facilities at no project cost provides a very substantial savings in cost.

\subsection{DEMOLITION AND REMOVAL OF EQUIPMENT}

Limited amounts of demolition and removal work must be performed at the HTGR facility to accommodate the equipment associated with the GCFR-CTF. The establishment of responsibility for cost estimates for the demolition and removal of equipment at HTGR was based on the following:

\subsubsection{GAC HTGR FACILITY RES PONSIBILITIES}

- The removal of existing equipment, and piping, from rooms where new equipment is to be installed.

\subsubsection{THE RALPH M. PARSONS COMPANY RESPONSIBILITIES}

- Structural demolition and removal

- Architectural demolition and removal

\subsection{RELATED OPERATING EXPENSE FUNDED COSTS}

This section includes costs that are directly related to the facility design, development and utilization but are not a part of the total estimated cost of the facility.

\subsubsection{RESEARCH AND DEVELOPMENT NECESSARY TO COMPLETE CONSTRUCTION}

The following research and development activities must be completed in order to specify the final facility design and construction features :

- Conceptual design and subcomponent development testing for the :

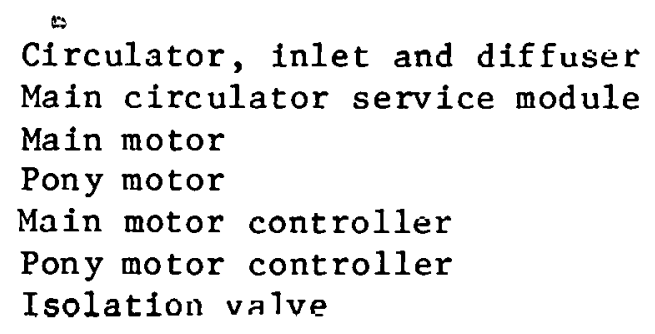




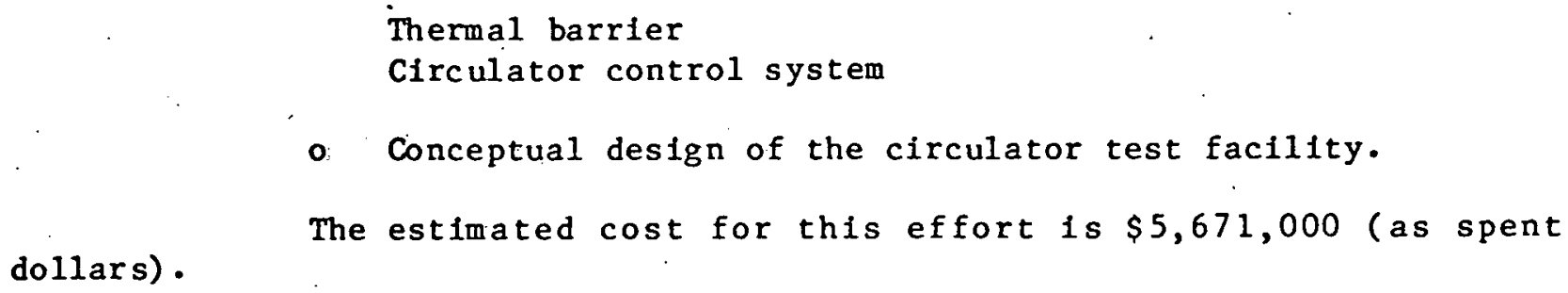

\subsubsection{PROGRAMMATIC OPERATING EXPENSES}

Programatic operating expenses directly related to the facility include the following activities conducted over a 8 year period:

- Project management, engineering support, preliminary design and final design of the:

Prototype

Circulator

Isolation valve

Main and pony motor

Diffuser

Main circulator service module

Main and pony motor controllers

Thermal barrier

Circulator control system

- Manufacturing of the above prototypes.

- Manufacturing of the No. 1 and 2 production units for the circulator.

The cost of the above programmatic activities is estimated at $\$ 22,981,000$ (as spent dollars).

\subsubsection{OPERATOR. TRAINING AND FACILITY CHECKOUT}

Operator training and facility checkout will take 10 months at an estimated cost of $\$ 1,204,000$ (as spent dollars).

\subsubsection{FACILITY OPERATING COSTS}

Facility operating costs include the following:

Installation and removal of the test items (not including

initial installation).

Salaries

Spare facility equipment parts

Consumables (helium, nitrogen, polishing lon exchange service, potable water, heating gas and electric power).

Facility operation is expected to last approximately 52 month.s at an estimated cost of $\$ 11,382,000$ (as ispent dollars): 


\subsubsection{CAPITAL EQUIPMENT COST}

Capital equipment cost is the cost for equipment that is portable or semi-portable and readily reusable elsewhere upon completion of the mission of this factlity. The principal type of equipment falling into this category is instrumentation. Total estimated capital equipment cost for this facility is $\$ 275,000$.

\subsubsection{OPERATING EXPENSE FUNDED SCHEDULE}

Table 7.5 and Schedule 7-1 shows dates and time spans for the expense funded items described above. 
TABLE 7-1

MODIFIED HTGR-HELIUM CIRCULATOR TEST FACILITY

TOTAL ESTIMATED COST SUMMARY

Base Cost - October 1979 Dollars

Escalation - As Spent Thousands of Dollars

Architect

Engineer

GAC Total

A. Engineering

Title I

$\begin{array}{rrr}618 & 268 & 886 \\ 1,485 & 471 & 1,956 \\ 698 & 738 & 1,436\end{array}$

Title III \& Project Administration

0

0

0

C. Construction Costs

1. Improvement to Land

2. Building - Modifications

3. Other Structures

4. Special Facilities:

a. Test Systems

Helium Loop

Rapid Depressurization System

3,642

108

Instrumentation and Control

544

$-\quad 3,642$

$-\quad 108$

$794 \quad 1,338$

b. Support Systems

Dowtherm System

Helium Supply and Storage System

581

523

Buffer Helium System

75

Nitrogen System

56

Vacuum System

23

Compressed Air System

155

High Purity Water

Cooling Water System

533

Electrical Power System

1,588 .

581

$-$

523

$\begin{array}{r}- \\ -\quad 75 \\ \hline\end{array}$

-
$-\quad 56$

- 23

-
$-\quad 155$
-

$-\quad 37$
$-\quad 533$

- $\quad 533$

- $\quad 1,588$

c. Test Hardware

Installation

449

449.

Handling Equipment

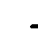

323

323 
TABLE 7-1 (Continued)

Architect/
Engineer

5. Utilities
a. Èlectrical
b. Other utilities

Standard Equipment

Removal and Salvage

Sub-total

Contingency $25 \%$

Sub-total

Construction Planning \& Design (CP\&D)

Total Estimated Cost of Facility

\section{GAC Total}

$\begin{array}{rrr}680 & - & 680 \\ 0 & - & 0 \\ 0 & - & 0 \\ 20 & -\cdots & 0\end{array}$

12,177

$\begin{array}{rr}2,611 & 14,788 \\ 650 & 3,694\end{array}$

15,221

3,261

18,482

420,420

18,902 
TABLE 7-2

ENGINEERING COST BREAKDOWN

ARCHITECT/ENGINEER

Title I - Preliminary Design

Cost

a. Engineering

b. Escalation $(.310)$

146

Subtotal

Title II - Final Design
a. Engineering
1,050
b. Escalation (.414)
435
Subtotal
$\overline{1,485}$

Title III - Inspection of Construction

a. Inspection \& Field Engineering

b. Escalation (.647)

Subtotal

$\overline{698}$

$\underline{\text { GAC }}$

Title I

a. GAC Liaison \& Project Management 103

b. Instrumentation \& Control Design 104

c. Purchasing 23

d. Escalation $(.166) \quad \frac{38}{268}$

Subtotal $\quad \frac{38}{268}$

\section{Title II}

a. GAC Liaison \& Project Management. 177

b. Instrumentation \& Control Design 167

c. Purchasing 30

d. Escalation (.260) $\frac{97}{471}$

Subtotal $\frac{97}{471}$

\section{Title III}

a. GAC Liaison \& Project Management 522

b. Instrumentation \& Control Field Engineering Test and Inspection 21

c. Escalation (.360) 195

Subtotal $\overline{738}$ 
TABLE 7-3

CONSTRUCTION COST BREAKDOWN

ARCHITECT/ENGINEER

C-1 Improvements to Land

Cost

Div. Item

1. . Gen. Requirements

14

2. Site Work 29

16. Electrical 37

Escalation $\quad 35$

Constr. Mgmnt.

C-2 Buildings-Modifications

Div. Item

1. Gen. Requirements

3. Concrete 18

5. Metals 5

7. Thermal \& Moisture Protection . . 1

8. Doors \& Windows . 4

9. Finishes : 18

15. Mechanical

Sect. 1-Plumbing

Sect. 2-Piping

37

Sect. 3-HVAC

Sect. 4-Fire Protection

16. Electrical \& Instrumentation

Escalation

45

Constr. Mgmnt.

SUBTOTAL

\section{C-4 Special Facilities}

a. Test System

Helium Loop

Div. Item

I. Gen. Requirements 436

3. Concrete 16

5. Metals 21

11. Equipment 1501

15. Mechanical 387

16. Electrical \& Instrumentation 110

Escalation 1087

Constr. Mgmnt. 
C-4 Special Facilities (cont'd)

a. Test System (Cont'd)

Rapid Depressurization

Div. Item

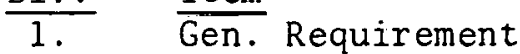

12

11. Equipment

15. Mechanical

12

16. Electrical \& Instrumentation . 39

Escalation

Constr. Mgmnt.

Instrumentation and Control

Div. Item

1. Gen. Requirements

16. Electrical \& Instrumentation (Installation) 291

Escalation $\quad 155$

Constr. Mgmnt.

SUBTOTAL

$\frac{36}{544}$

b. Support Systems

Dowtherm System

\begin{tabular}{rlr}
\hline Div. & Item \\
\hline 1. & Gen. Requirements & 68 \\
3. & Concrete & 8 \\
5. & Metals & 1 \\
11. & Equipment & 195 \\
15. & Mechanical & 99 \\
16. & Electrical \& Instrumentation & 14 \\
& Escalation & 169 \\
& Constr. Mgmnt. & 27 \\
& SUBTOTAL & 581
\end{tabular}

Helium Supply \& Storage System

Div. Item

1. Gen. Requircments 61

3. Concrete 15

11. Equipment 214

15. Mechanical 55

16. Electrical \& Instrumentation 1

Escalation 152

Constr. Mgmnt. $\quad \frac{25}{523}$

$\overline{523}$ 
C-4 Special Facilities (Cont'd)

b. Support Systems (Cont'd)

Buffer Helium System

Div. Item

1. Gen. Requirements

11. Equipment

15. Mechanical

16. Electrical \& Instrumentation

Escalation

Constr. Mgmnt.

SUBTOTAL

$\begin{array}{r}9 \\ 26 \\ 6 \\ 8 \\ 21 \\ 5 \\ \hline 75\end{array}$

Nitrogen System

Div: Item

1. $\quad$ Gen. Requirements

11. Equipment

15. Mechanical

16. Electrical \& Instrumentation

Escalation

Constr. Mgmnt.

Vacuum System

Div. Item

1. $\quad \frac{\text { Gen. Requirements }}{3}$

11. Equipment

15. Mechanical

16. Electrical \& Instrumentation

Escalation

Constr. Mgmnt

SUBTOTAL

Compressed Air System

Div. Item

1. $\quad \overline{\text { Gen. Requirements }} 18$

11. Equipment 53

15. Mechanical 27

16. Electrical \& Instrumentation 3

Escalation $\quad 44$

Constr. Mgmnt.

SUBTOTAL 
C-4 Special Facilities (Cont'd)

b. Support Systems (Cont'd)

High Purity Water

Div. Item

1. Gen. Requirements

11. Equipment

15. Mechanical

15. Mechanical 1 Electrical \& Instrumentation

Escalation

Constr. Mgmnt. SUBTOTAL

Cooling Water System

Div. Item

1. Gen. Requirements

3. Concrete

11. Equipment

15. Mechanical

16. Electrical \& Instrumentation

Copstr. Mgmnt.

Electrical Power System Div. Item

1. Gen. Requirements

16. Electrical \& Instrumentation . 874 $\begin{array}{ll}\text { Escalation } & 467\end{array}$

Constr. Mgmnt.

Installation of Test Hardware Div. Item

$\frac{\text { I. }}{\text { Gen. Requirements }}$

11. Equipment

15. Mechanical

Escalation

Constr. Mgmnt. 


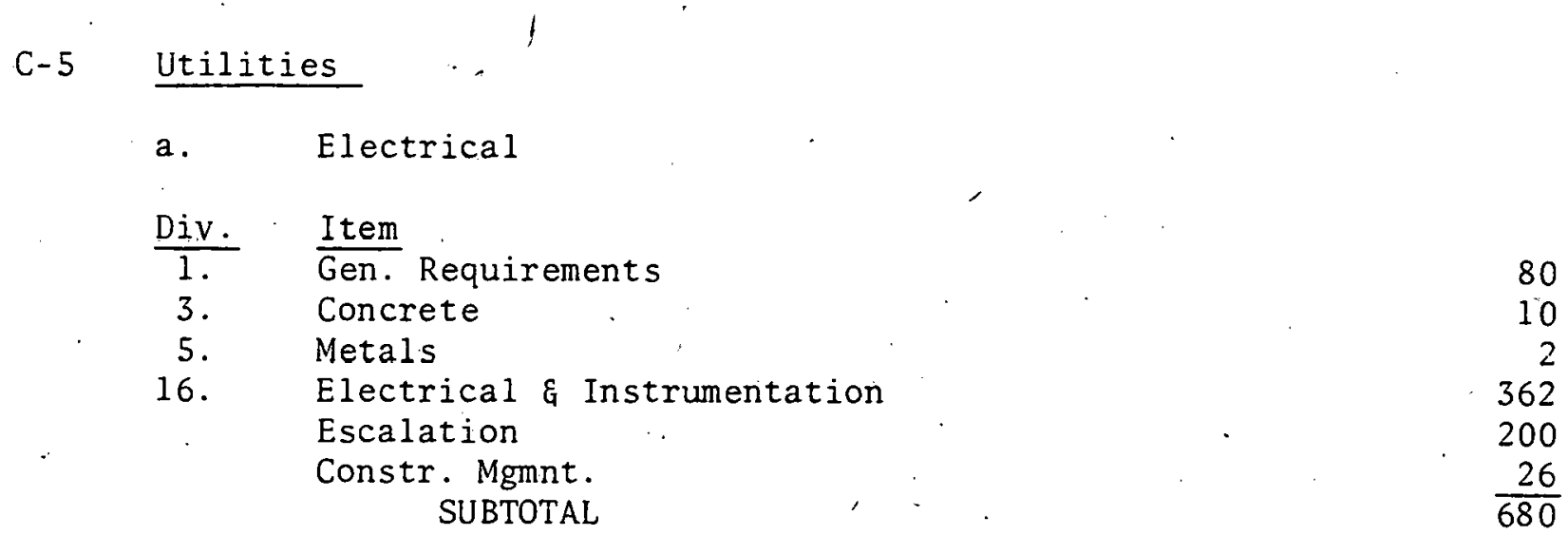

E. Removal and Salvage

\begin{aligned} \hline Div. & Item \\ \hline 3. & Concrete \\ 7. & Thermal and Moisture Protection \\ 8. & Doors and Windows \\ 9. & Finishes \\ 15. & Mechanical \\ & Escalation \\ & Constr. Mgmnt. \\ & SUBTOTAL \end{aligned}

\begin{tabular}{c}
3 \\
8 \\
0 \\
0 \\
1 \\
1 \\
6 \\
1 \\
\hline 20
\end{tabular}


TABLE 7-3 (Continued)

GAC' FURNISHED EQUIPMENT

\section{C-1 Improvement to Land}

Cost

Environmental Impact Reports

Escalation

\section{C-4 Special Facilities}

a. Test Systems

Instrumentation \& Control

581

Escalation

SUBTOTAL

c. Test Hardware

Handling Equipment

Escalation 
TABLE $7-4$

MODIFIED HGTR HELIUM CIRCULATOR TEST FACILITY

FACILITY FINANCIAL SCHEDULE

FOR GAC FACILITY

(As Spent Dollars in Thousands)

\begin{tabular}{|c|c|c|c|c|}
\hline & $\begin{array}{c}\mathrm{A} / \mathrm{E} \\
\text { Engineering } \\
\end{array}$ & $\begin{array}{l}\text { GAC } \\
\text { Furnished } \\
\text { Equipment }\end{array}$ & Construction & Total \\
\hline FY -78 & - & $100^{(1)}$ &.- & 100 \\
\hline$F Y-79$ & - & $320^{(1)}$ & - & 320 \\
\hline FY -80 & - & - & - & - \\
\hline$F Y-81$ & - & - & - & - \\
\hline FY-82 & 2,165 & 715 & - & 2,880 \\
\hline$F Y-83$ & 930 & 1,976 & 5,123 & 8,029 \\
\hline FY -84 & 406 & 570 & 6,597 & 7,573 \\
\hline Total & 3,501 & 3,681 & 11,720 & 18,902 \\
\hline
\end{tabular}

${ }^{(1)}$ Construction Planning \& Design, CP\&D 


\section{TABLE 7-5}

GCFR HELIUM CIRCULATOR TEST FACILITY

OPERATING COST FINANCIAL SCHEDULE

AS SPENT DOLLARS IN THOUSANDS

\begin{tabular}{|c|c|c|c|c|c|c|c|c|c|c|c|c|}
\hline TASK & $\begin{array}{l}\text { Prior } \\
\text { Years }\end{array}$ & 1980 & 1981 & 1982 & 1983 & 1984 & 1985 & 1986 & 1987 & 1988 & 1989 & TOTAL \\
\hline $\begin{array}{l}\text { RED Necessary to } \\
\text { Complete Construction }\end{array}$ & 2,003 & 1,621 & 2,047 & & & & & & & & & 5,671 \\
\hline $\begin{array}{l}\text { Programnatic Operating } \\
\text { Expenses }\end{array}$ & & 671 & 1,536 & 7,062 & 11,403 & 1,982 & 84 & 91 & 98 & 54 & & 22,981 \\
\hline $\begin{array}{l}\text { Operator Training And } \\
\text { Facility Checkout }\end{array}$ & & & & & & 462 & 742 & . & & & & 1,204 \\
\hline $\begin{array}{l}\text { Facility Operation } \\
\text { Costs }\end{array}$ & & & & & & & 1,049 & 2,257 & 2,469 & 2,690 & 2,917 . & 11,382 \\
\hline Capital Equipment & & & & & 235 & 40 & & & & & & 275 \\
\hline TOTAL & 2,003 & 2,292 & 3,583 & 7,062 & 11,638 & 2,484 & 1,875 & 2,348 & 2,567 & 2,744 & 2,917 & 41,513 \\
\hline
\end{tabular}


SCHEDULE 7-1

OPERATING EXPENSE FUNDED ITEMS

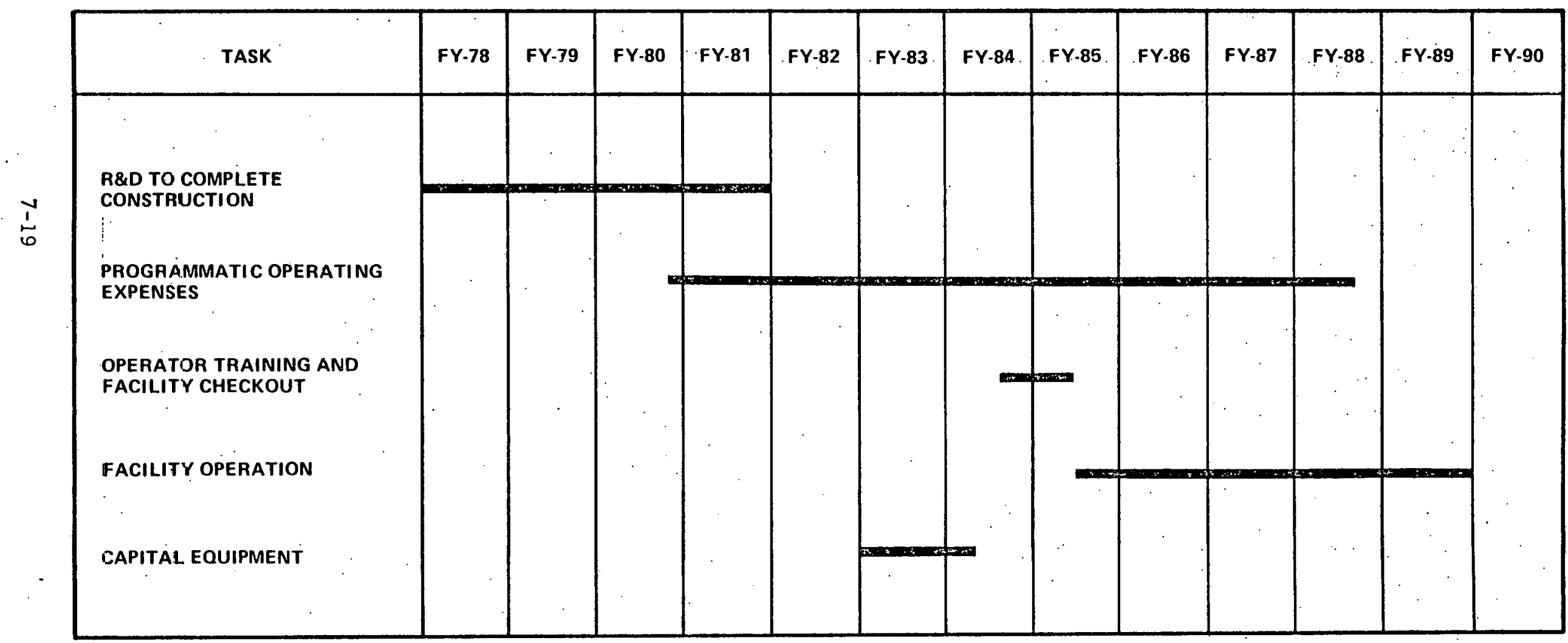


SECTION 8 DRAWINGS 


\section{SECTION 8}

DRAWINGS

This section contains drawings prepared for the modified HTGR facility at the GAC.

\subsection{TEST HARDWARE DRAWINGS}

$\begin{array}{ll}\text { EE-2748 } & \begin{array}{l}\text { GCFR Helium Circulator Test Facility } \\ \text { Schematic-Indirect Cooled External Helium Loop. }\end{array} \\ 025031 \text { Sht I } & \text { GCFR Main Circulator Horizontal Installation. } \\ 025205 & \text { Main Valve - Horizontal Installation. } \\ 024790 & \begin{array}{l}\text { GCFR Circulator Test Facility Main Motor } \\ \text { Controller. }\end{array} \\ 1819 \text { B23 Sht 1 } & \text { Air Cooled Synchronous Motor Outline. } \\ 024696 \text { Sht } 3 & \text { GCFR Main Circulator Installation }\end{array}$




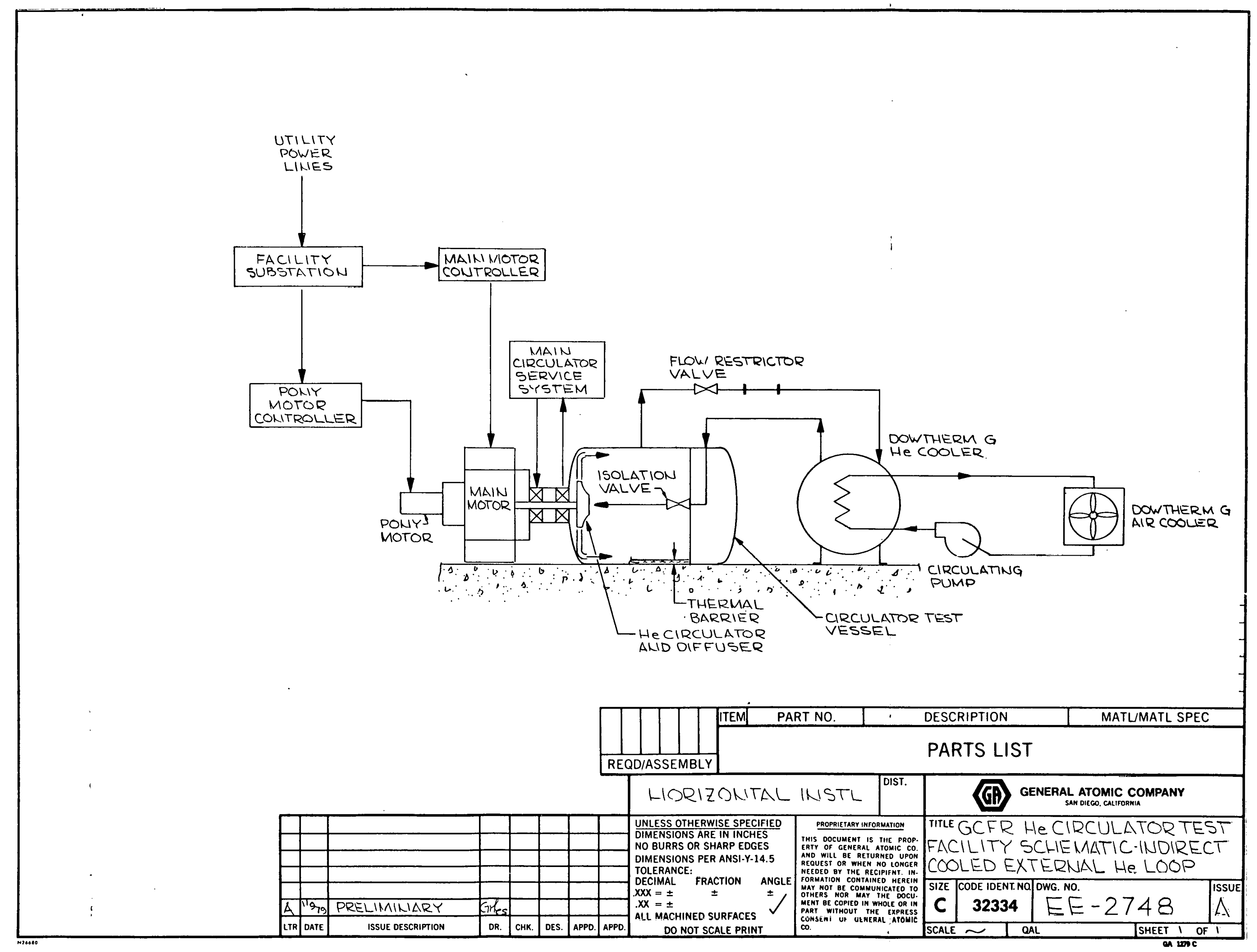




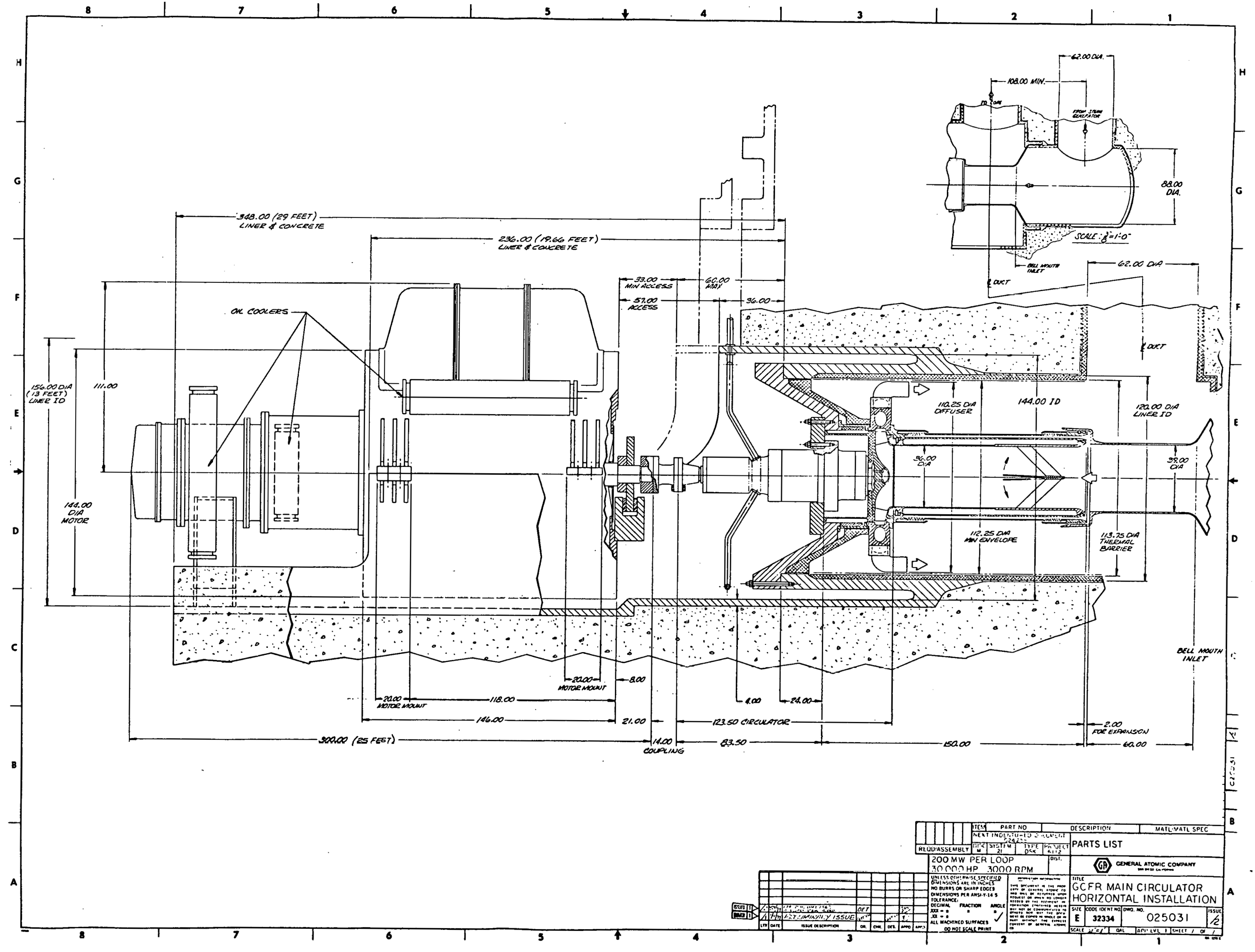




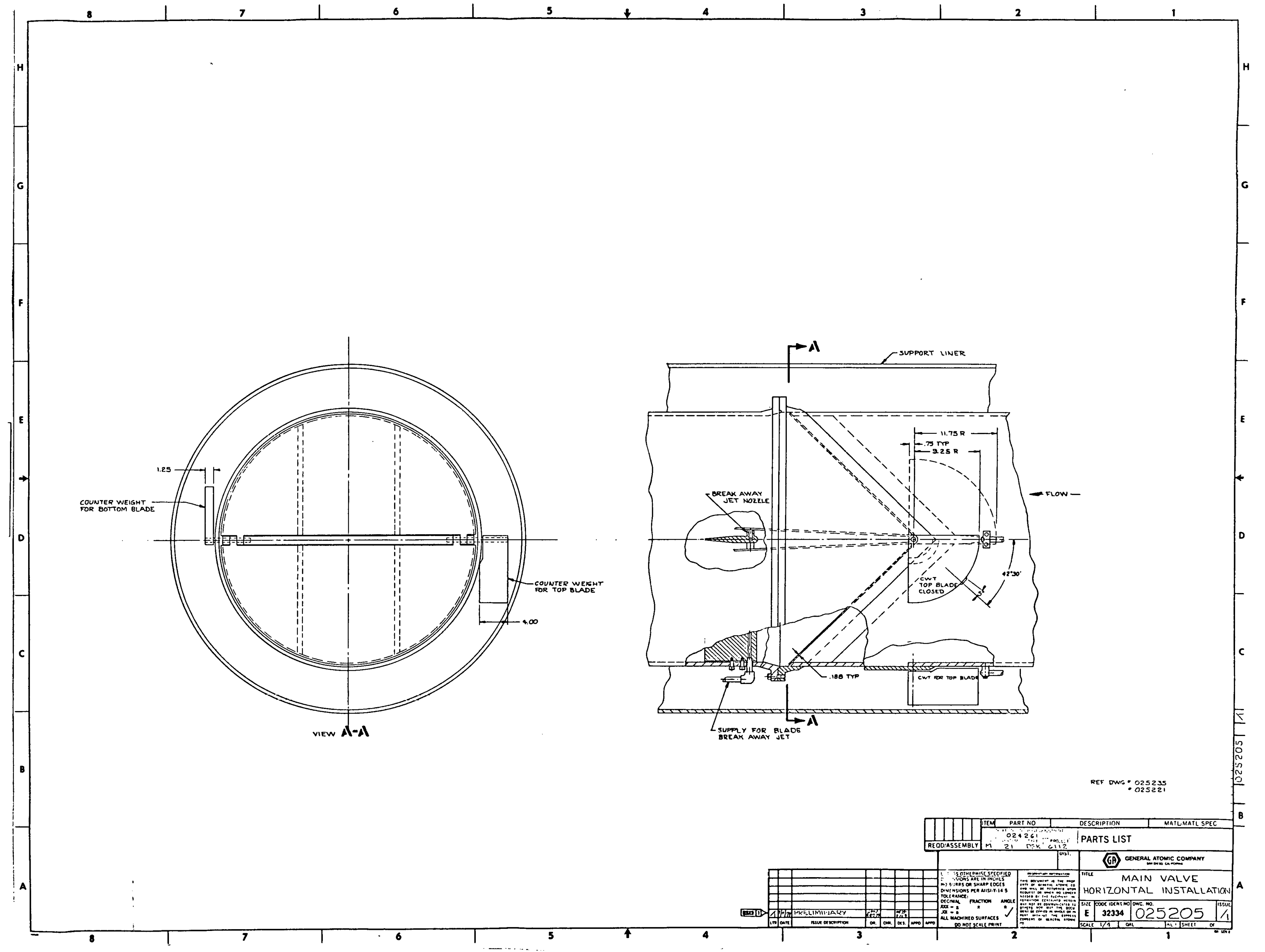




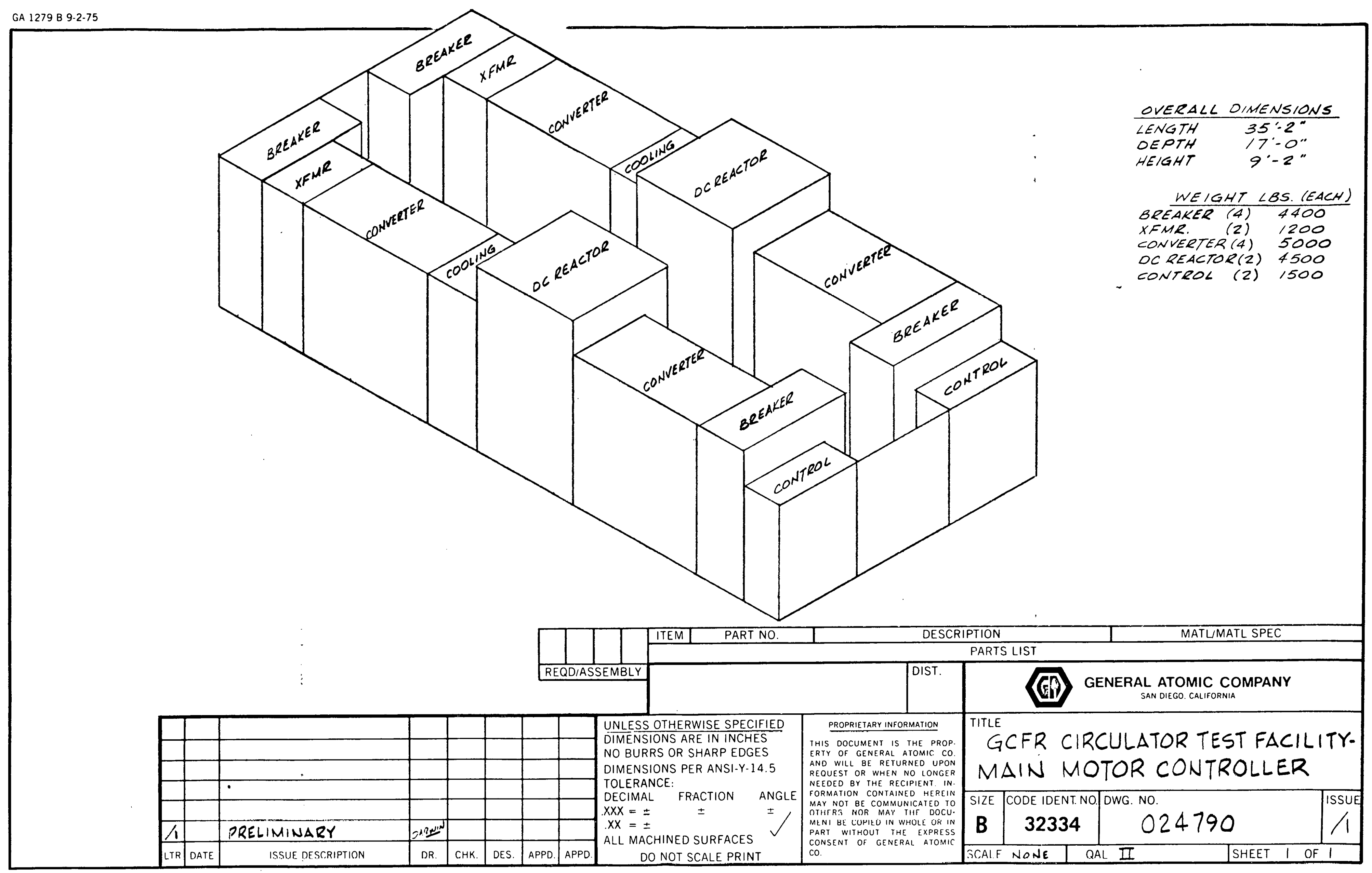




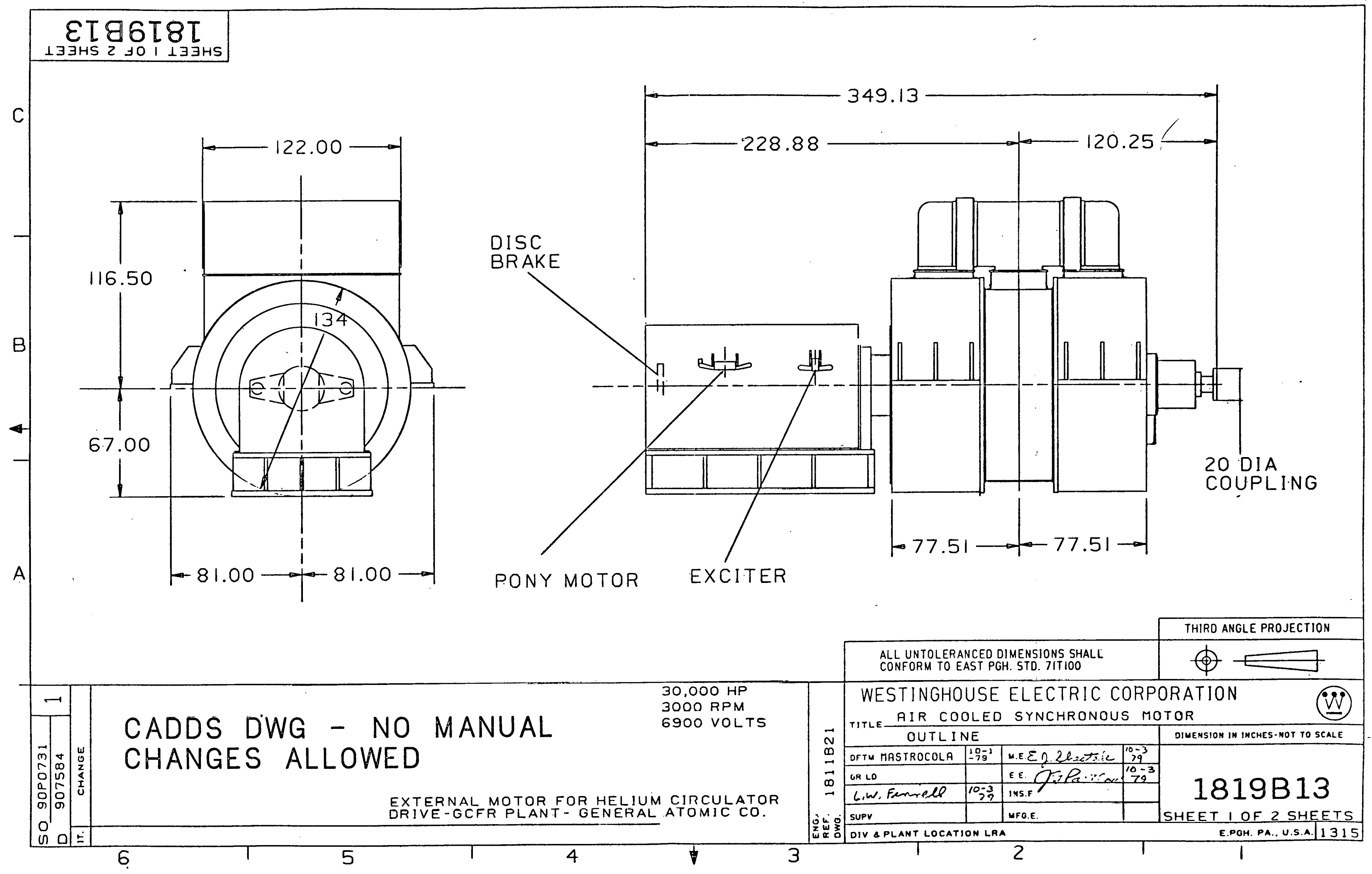




\subsection{FACILITY DRAWINGS}

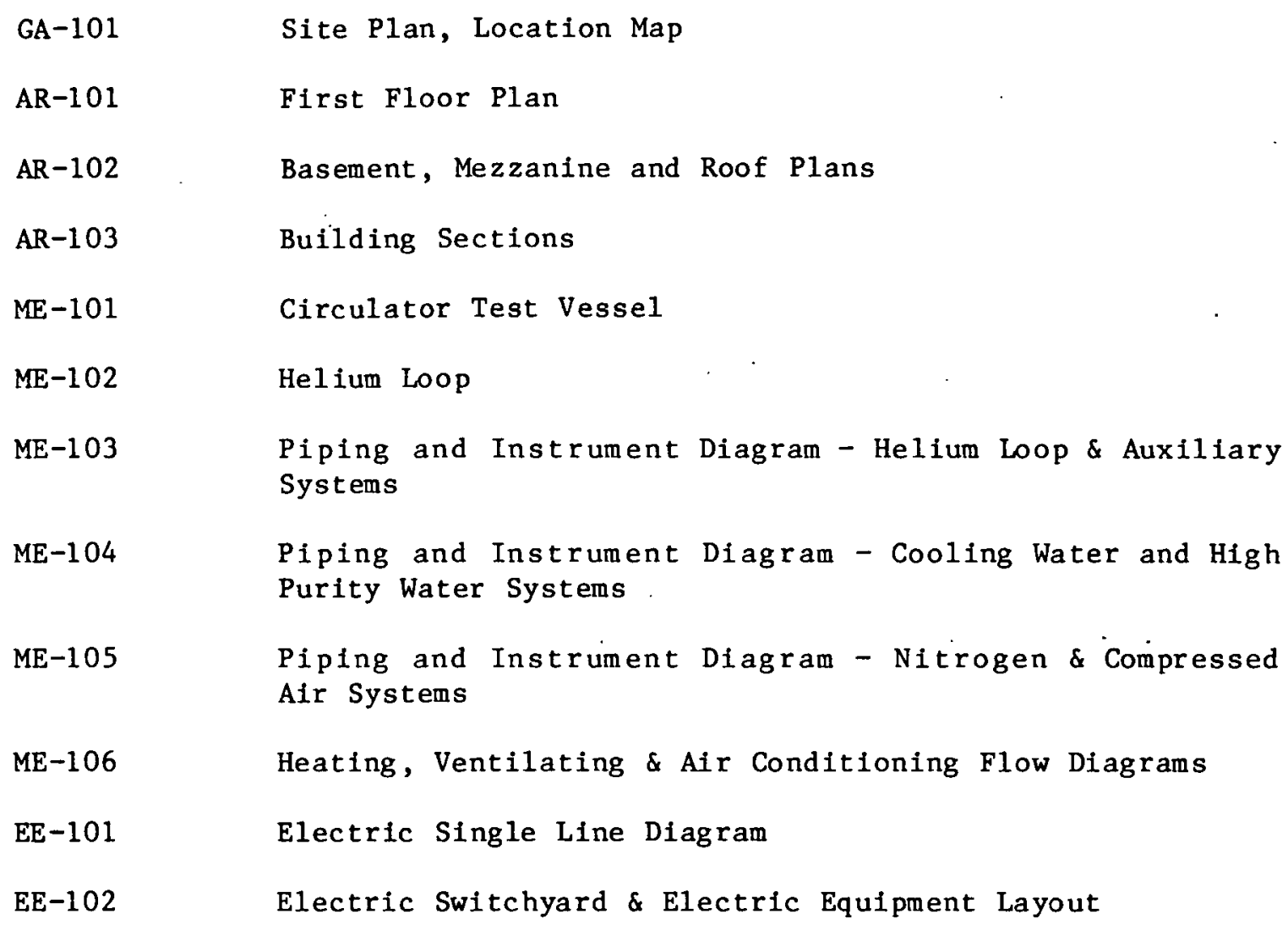




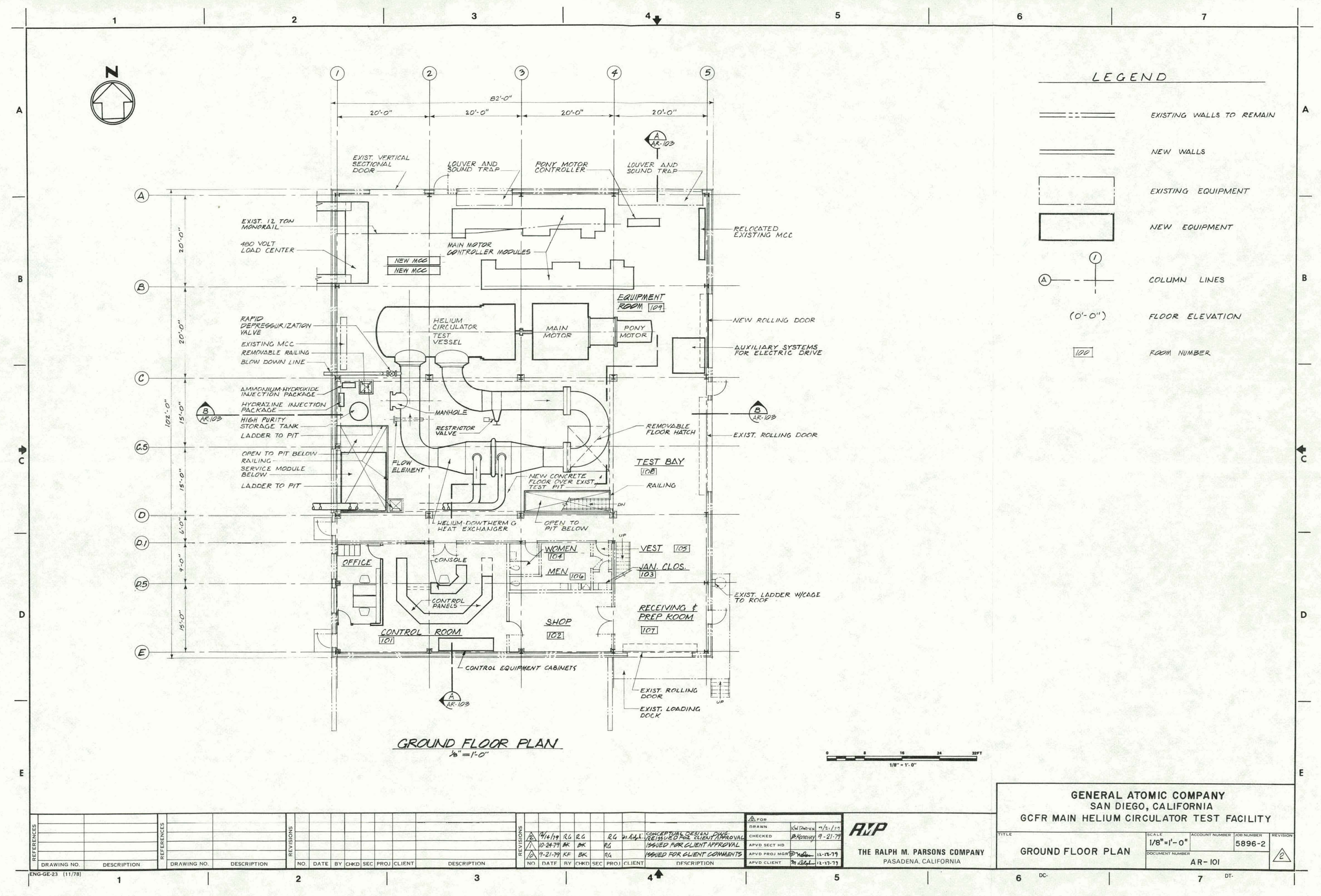




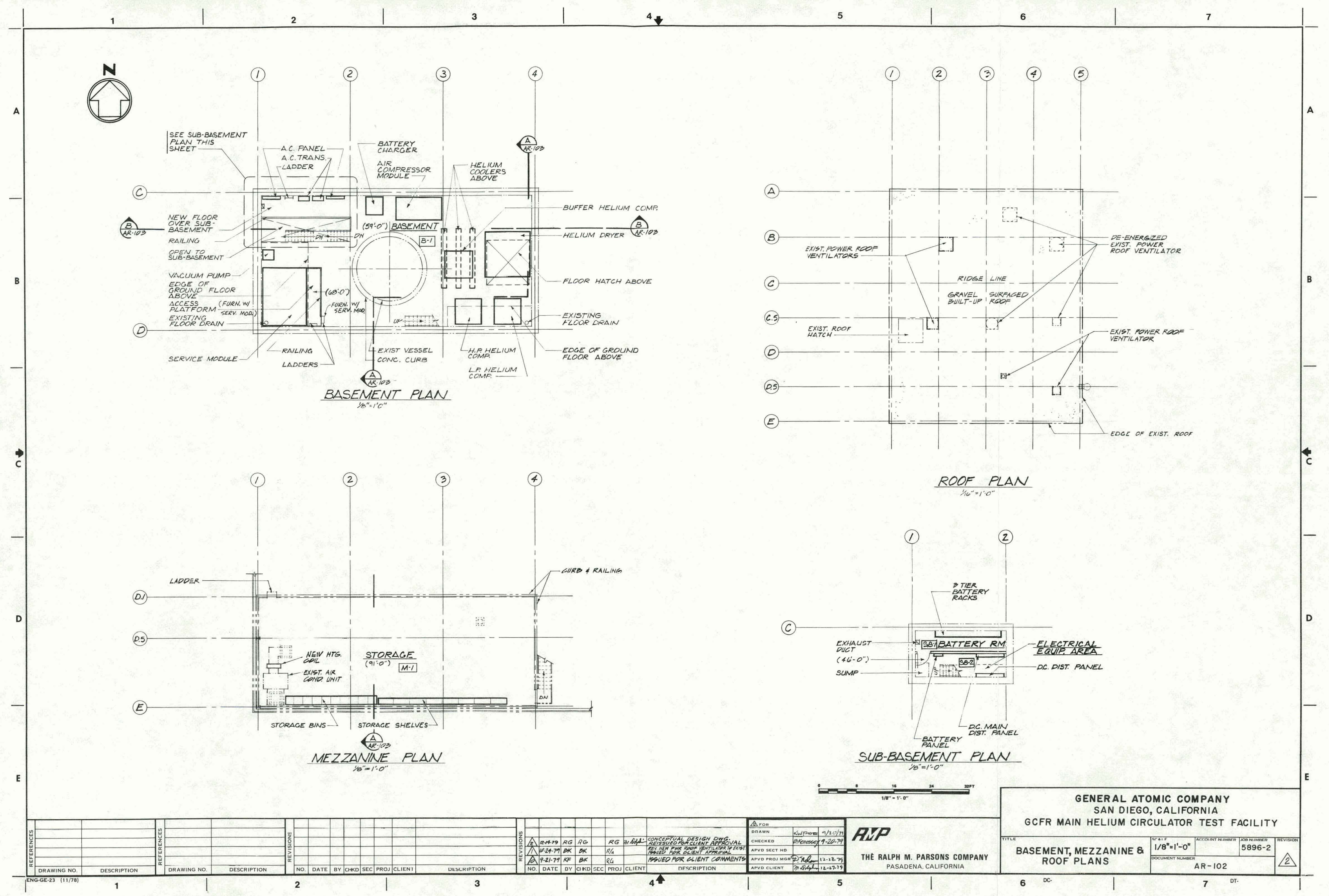




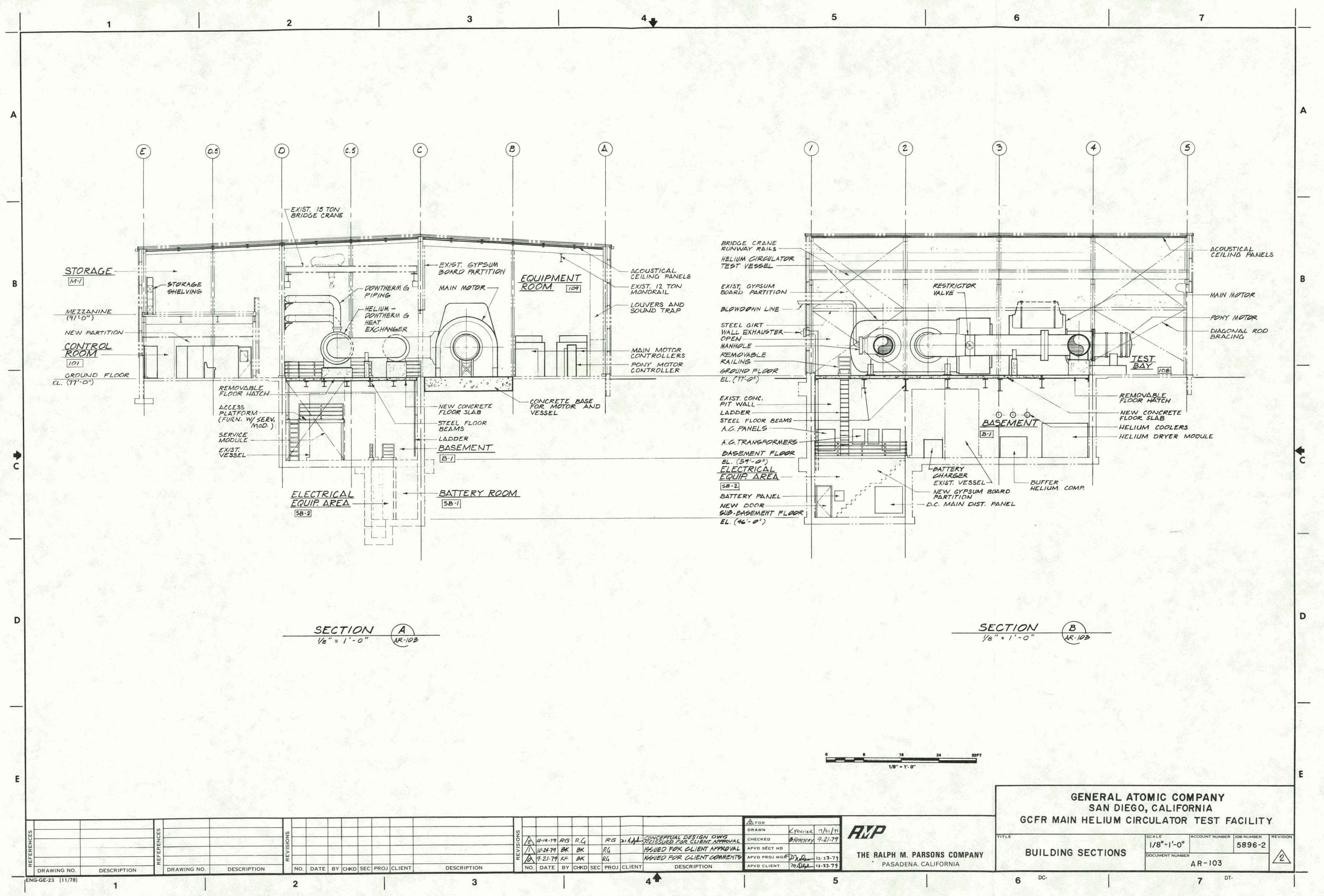




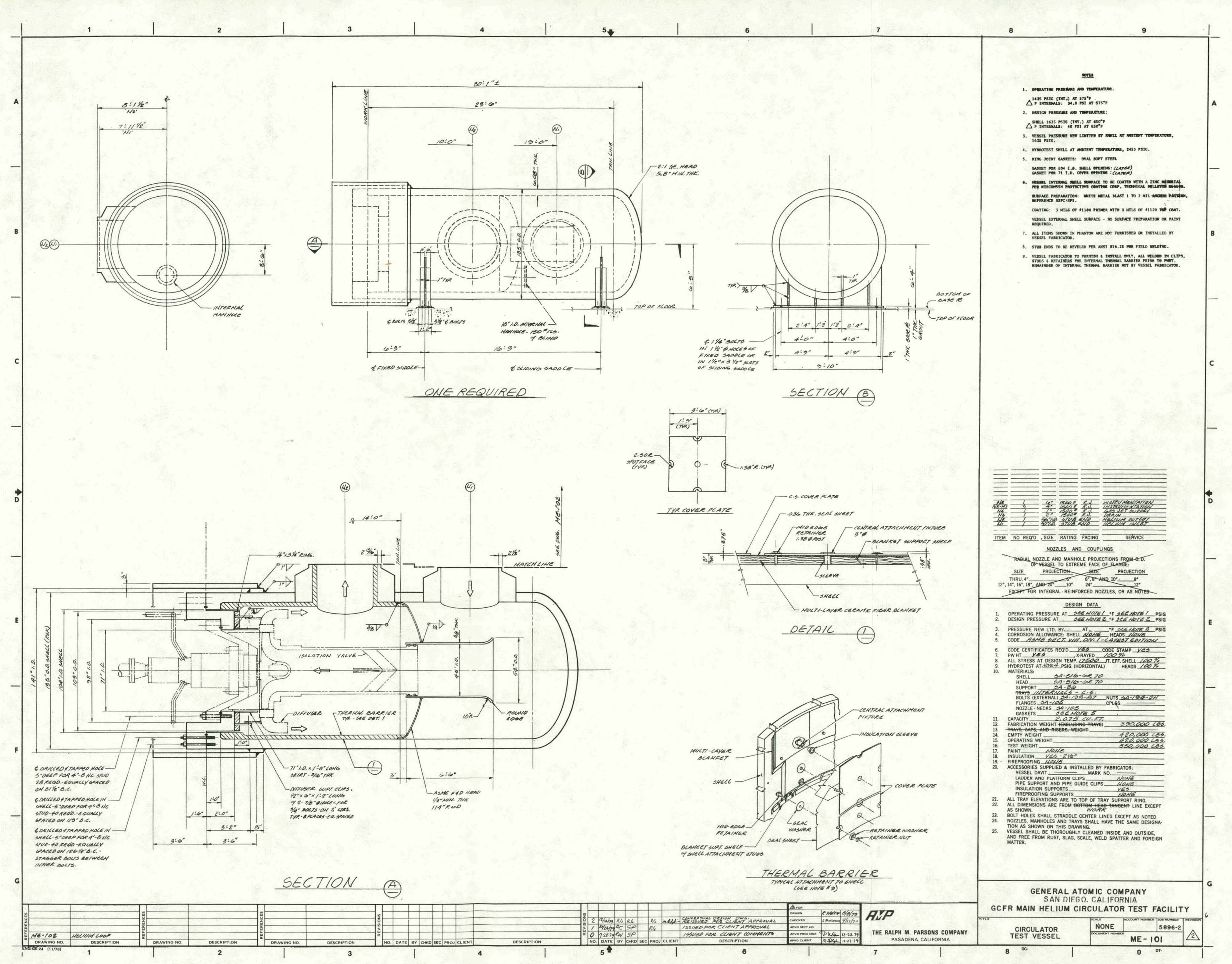




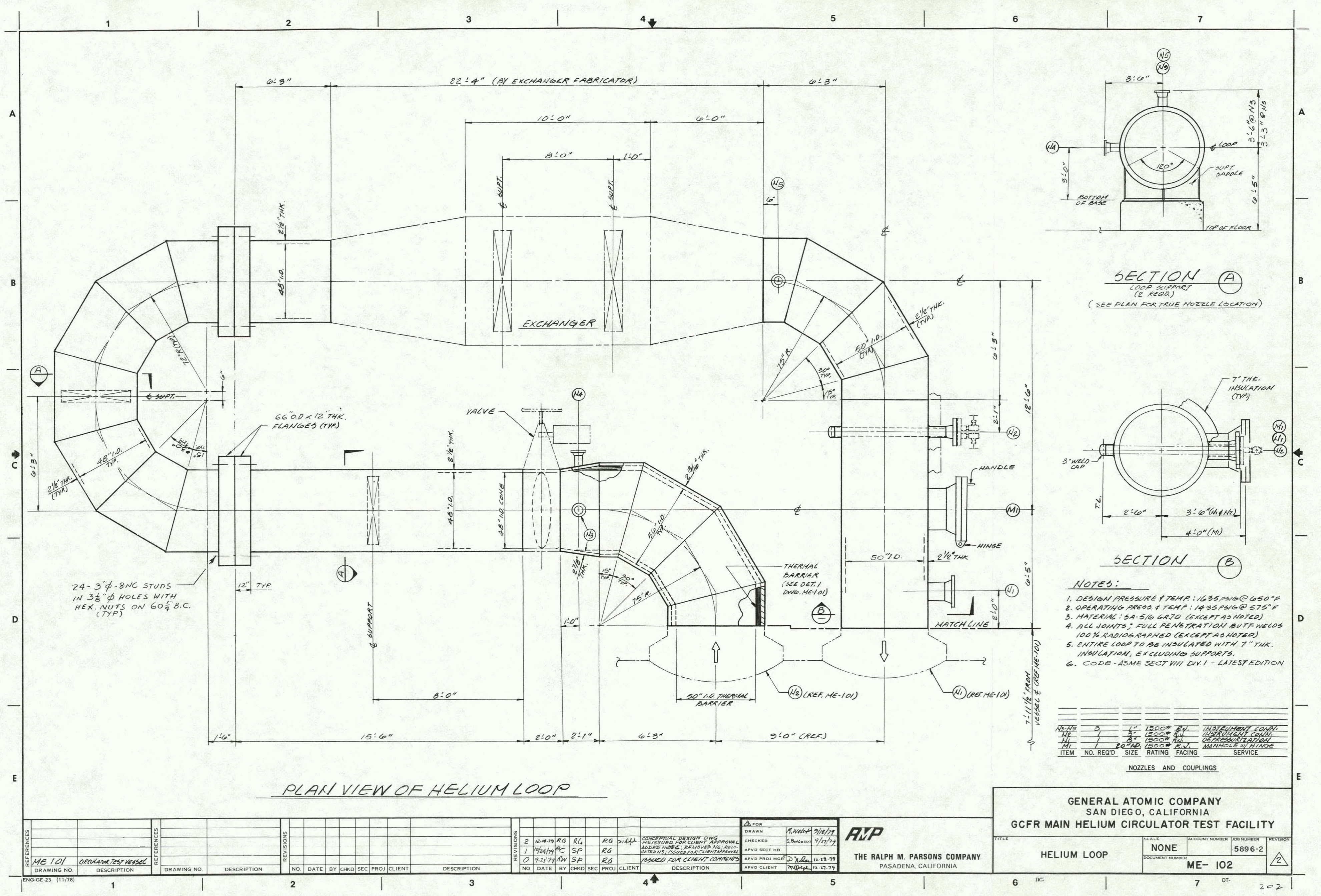




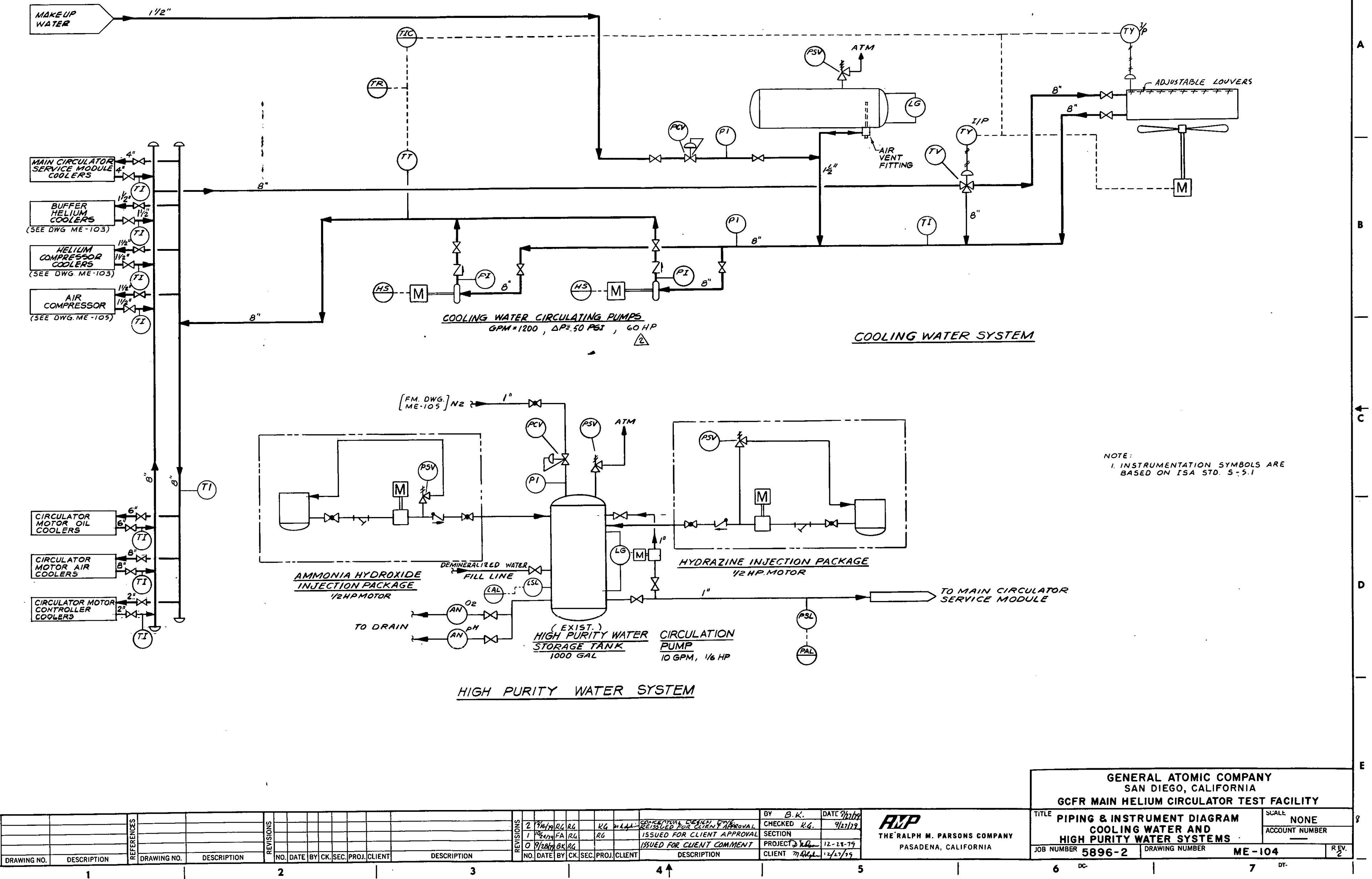


เำ

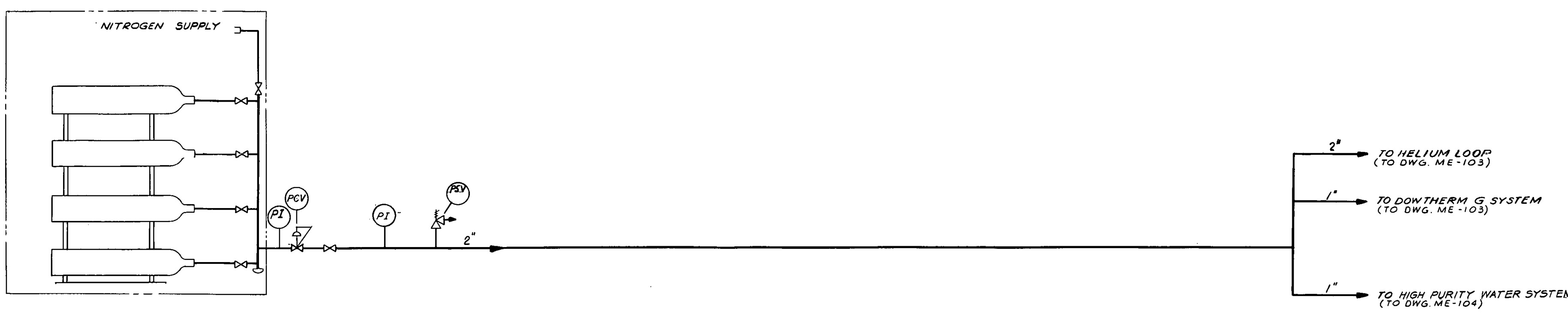

$\frac{\text { NITROGEN SUPPLY BOTTLES }}{\text { TOTAL STORAGE VOLUME }=420 \text { CU.FT }}$

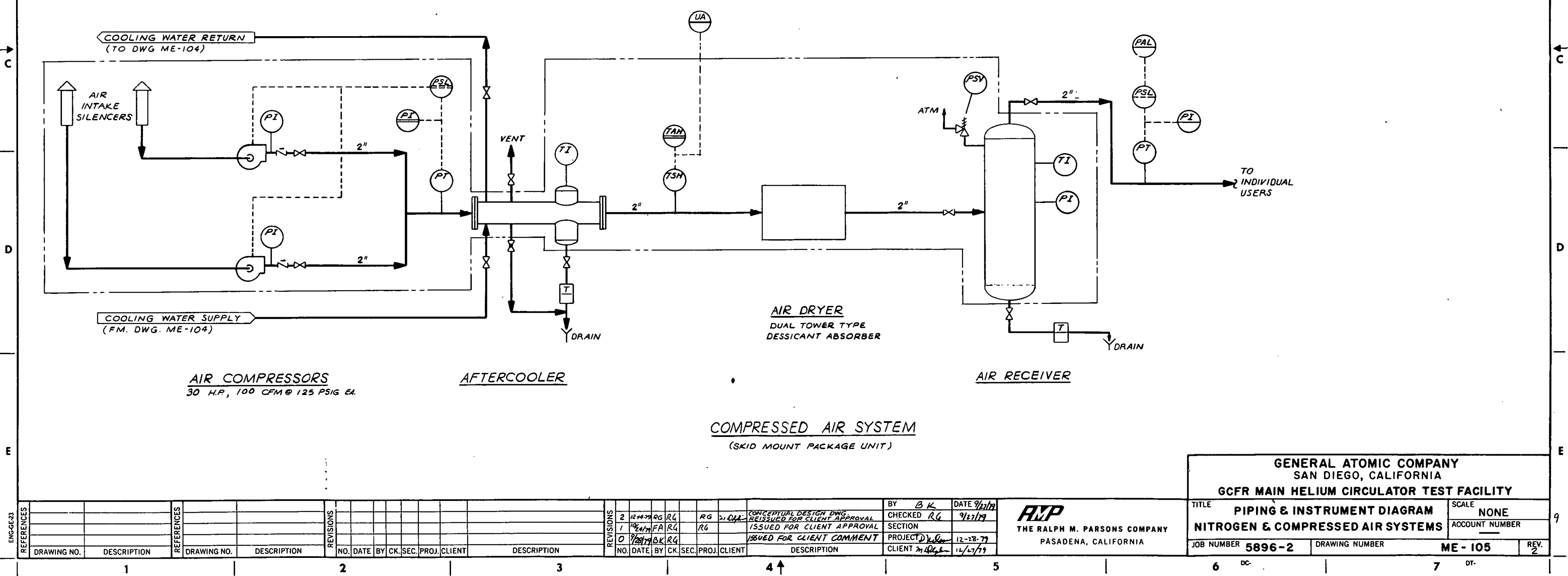




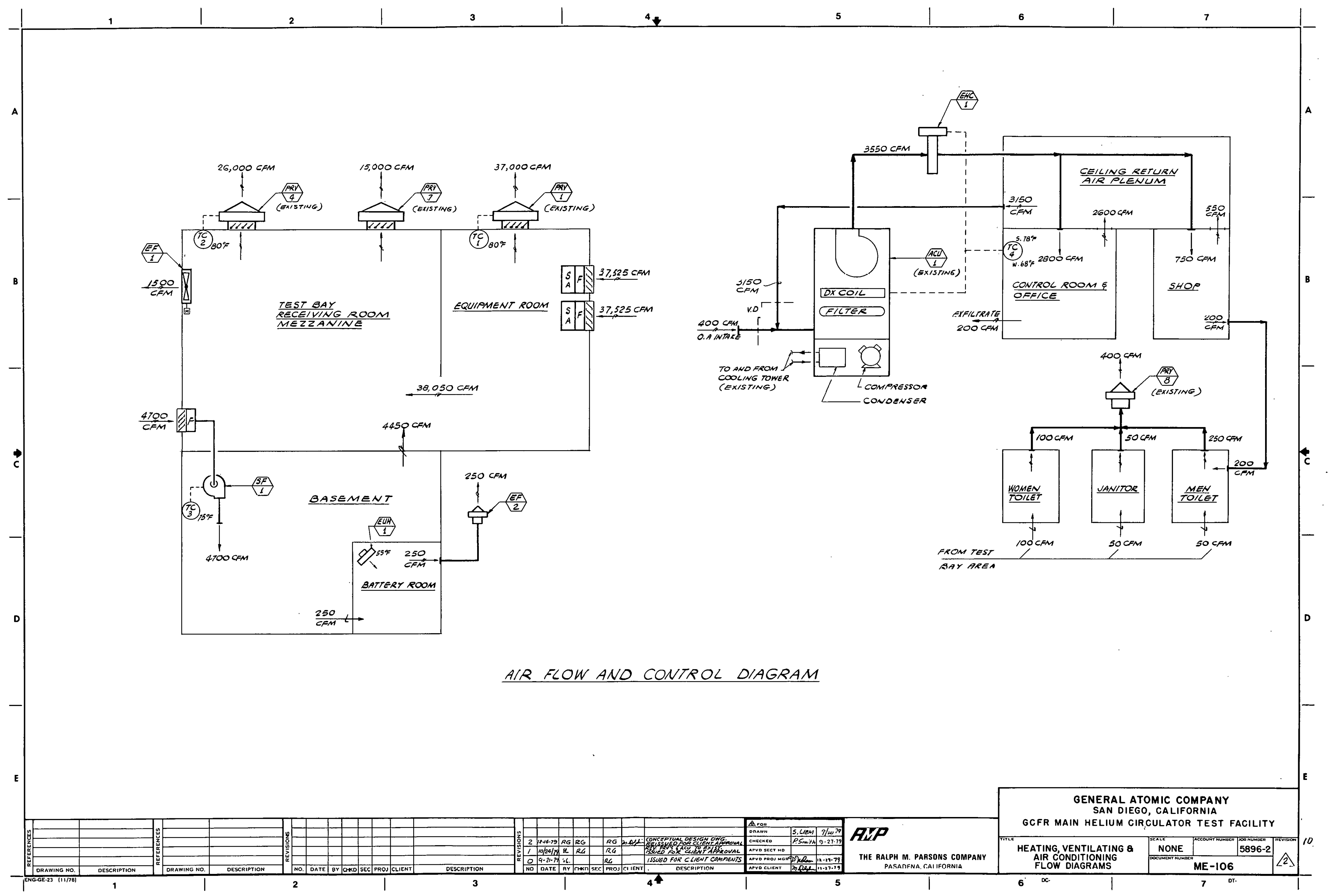


$\Rightarrow-\infty$ coses

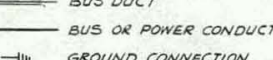

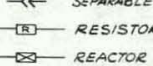

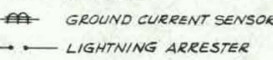

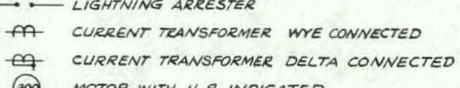

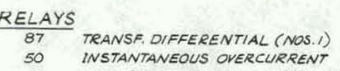

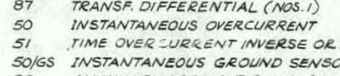

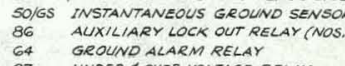

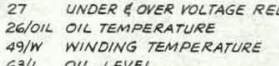

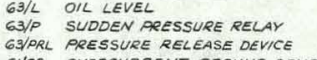

MEERS ISTREMENT

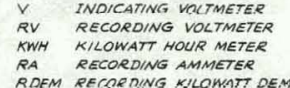

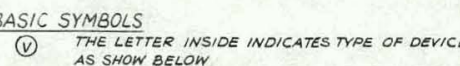

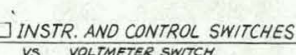

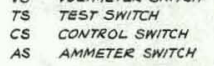

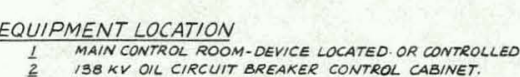

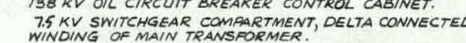

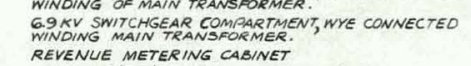

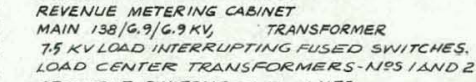

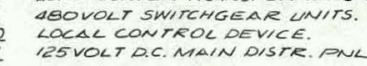

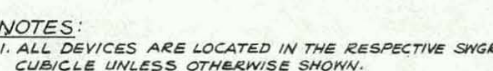

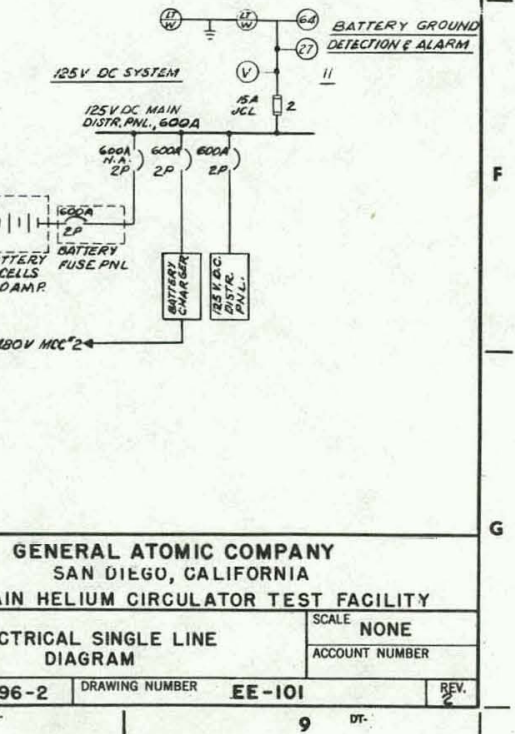




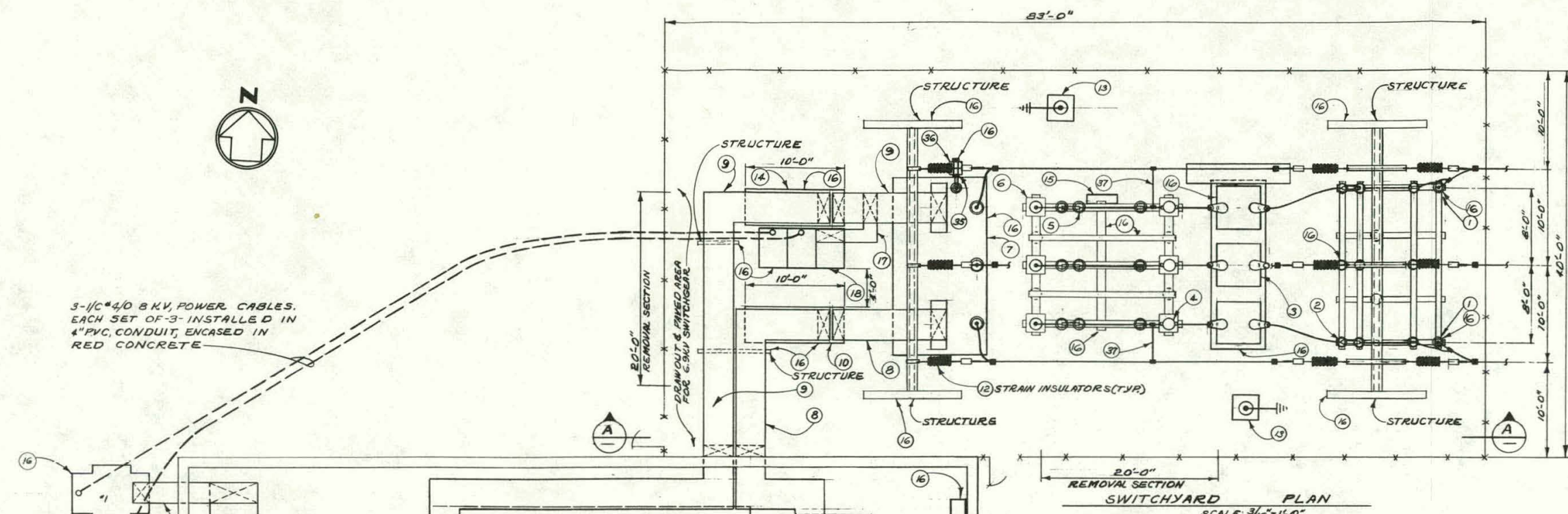

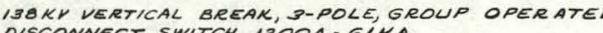

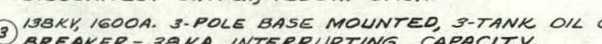

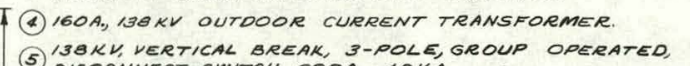

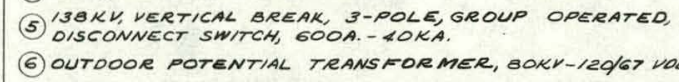

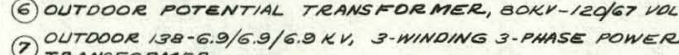

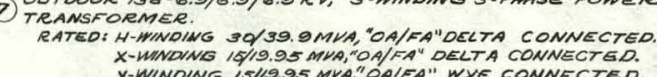

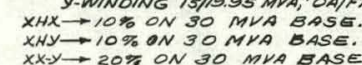

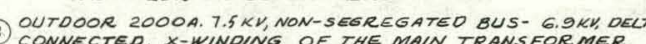

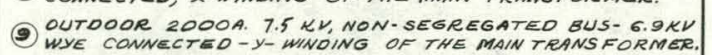

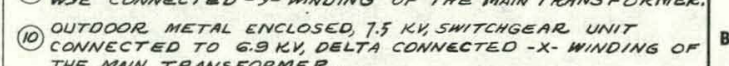

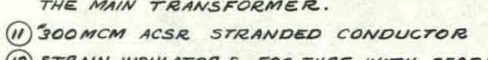

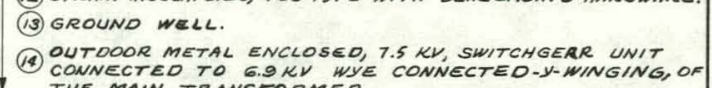
(3) OUTDOOR REVENUE METERING CABINET - Grounding GRID CONNECTIONS.

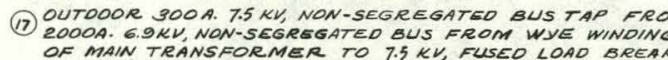

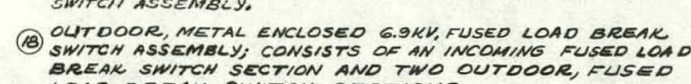

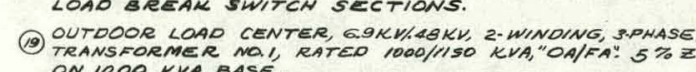

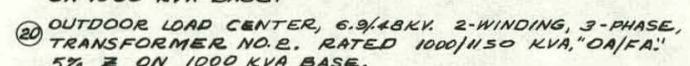

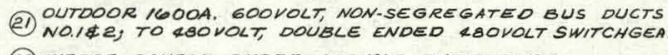

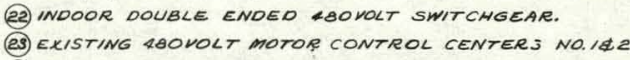

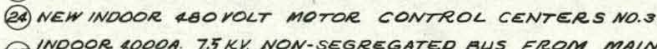

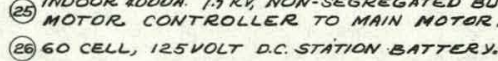

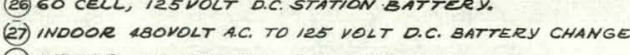

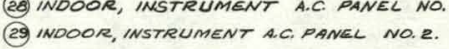

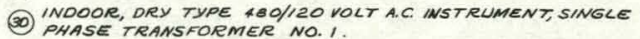

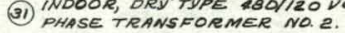

(1) LADOER PLAN GROUND FLOOR
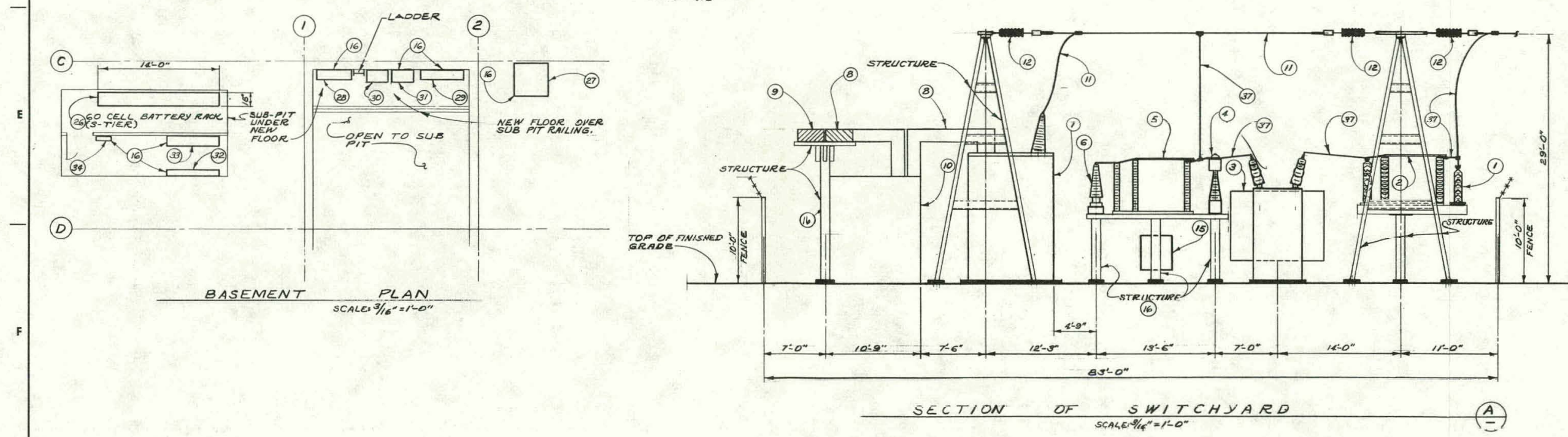

GENERAL ATOMIC COMPANY
SAN DIEGO GALLFPAN (3) NEUTREL GROUNDING COPPER STRAP CONNECTING

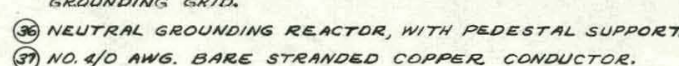


SECTION 9

OUTLINE SPECIFICATIONS 


$\begin{array}{ll} & \text { Page } \\ \text { INTRODUCTION } & 9-1 \text { i } \\ \text { DIVISION } 1-\quad \text { General Requirements } & 9-1 \\ \text { DIVISION } 2 \text { - Site Work } & 9-1 \\ \text { DIVISION } 3-\quad \text { Concrete } & 9-2 \\ \text { DIVISION } 4-\quad \text { Masonry } & 9-2 \\ \text { DIVISION } 5-\text { Metals } & 9-2 \\ \text { DIVISION } 6-\text { Wood and Plastics } & 9-3 \\ \text { DIVISION } 7-\text { Thermal and Moisture Protection } & 9-3 \\ \text { DIVISION } 8-\text { Doors and Windows } & 9-3 \\ \text { DIVISION } 9-\text { Finishes } & 9-4 \\ \text { DIVISION } 10-\text { Specialities } & 9-6 \\ \text { DIVISION } 11-\text { Equipment } & 9-6 \\ \text { DIVISION } 12-\text { Furnishings } & 9-11 \\ \text { DIVISION } 13-\text { Special Construction } & 9-11 \\ \text { DIVISION } 14-\text { Conveying Systems } & 9-13 \\ \text { DIVISION } 15-\text { Mechanical } & 9-21 \\ \text { DIVISION } 16-\text { Electrical and Instrumentation } & \end{array}$




\section{INTRODUCTION}

The Outline Specification is organized in accordance with The CSI Format for construction specifications. Most of the 16 standard divisions are subdivided into "broadscope" sections which identify or describe materials or equipment intended for use on the project.

Unless stated otherwise, wherever a specific manufacturer is given, "or equal" is implied.

Along with the drawings, the Outline Specification provides the basis for the cost estimate. 


\section{DIVISION 1 - GENERAL REQUIREMENTS}

This division of the Outline Specification would normally be used to identify unusual or out-of-the-ordinary requirements for the construction of the project that might impact either schedule or cost. Examples might be stringent quality assurance, tight noise or dust control, bad weather conditions, difficult logistics, etc.

There are no identifiable unusual general conditions or requirements for this project at this time.

\section{DIVISION 2 - SITE WORK}

\section{Section 1 - Clearing}

The clearing shall consist of the removal and disposal of all brush, roots and other organic matter, debris, trash and all other obstructions.

\section{Section 2 - Earthwork}

The earthwork shall consist of cutting, filling and compacting fill to finish grade, providing subgrades for paving, and the removal of waste material. Fill and backfill shall be compacted to 95 percent of maximum density in accordance with ASTM Specification D-1557.

All subgrades for paving shall be finished to a true compacted surface.

The new site work shall be graded to give adequate drainage, and to blend into the existing contours.

\section{Section 3 - Paving and Surfacing}

Bituminous paving shall consist of material specified and shall be placed in accordance with the State of California, Department of Transportation Construction Materia1.

\section{Section 4 - Fencing}

A 10-foot chain link galvanized steel security fence, topped with 3 strands of barbed wire, shall be supplied around the switchyard.

All tubular members shall conform to ASTM-A120 for weight and coating. All structural shapes shall conform to ASTM-A123 for galvanized coating.

Gate posts shall be 3 inch dia. pipe for personnel gates and 4 inch dia. for truck gates. End and line posts shall be 3 inch dia. pipe. Chain link fabric shall be 2 inch mesh with 9 gauge wire. 
DIVISION 3 - CONCRETE

\section{Section 1 - Concrete Reinforcement}

All reinforcing bars shall be new deformed billet-steel conforming to ASTM A615, Grade 60. Al1 welded wire fabric shall conform to ASTM A185.

\section{Section 2 - Cast-in-Place Concrete}

All cast-in-place concrete shall meet the requirements of quality spectfled in Chapter 4 of the ACI 318, reaching a strength of 3000 psi at 28 days.

\section{DIVISION 4 - MASONRY}

\section{Section 1 - Masonry Units}

Concrete block shall be load bearing hollow units, moisture controlled, conforming to ASTM C90, Type I, Grade N-I. The concrete block units shall match the existing units in size, color and texture. ASTM C476.

Mortar and grout shall be a mixture of materials in conformance with

Steel bar reinforcement shall be new preformed type conforming to ASTM A615, Grade 60 .

DIVISION 5 - METALS

Section 1 - Structura1 Stee1

Structural steel shall conform to ASTM Specification A-36, and shall be detailed, fabricated and erected in accordance with AISC Specifications and Code of Standard Practice. All welding shall conform to the American Welding Society Specification D.1.1

Bolts used to connect structural steel shall conform to ASTM Specification A-325. Anchor bolts shall conform to Specification ASTM A-307.

All fabricated carbon steel shall be painted with one shop coat of primer.

\section{Section 2 - Steel Floor Deck}

Steel floor deck used as subfloor shall be formed from steel sheet conforming to galvanized coated steel sheets of structural quality coils and cut lengths, ASTM designation A-446, and Federal Specification Q.Q-S-775a, Type 1, Class D. Minimum coating 1.25 ounces per square foot; minimum yield strength 33000 psi. Welding to supports shall conform to the American Welding Society. 


\section{Section 3 - Miscellaneous Metals}

Miscellaneous metal includes steel access ladders, stairs, catwalks, railings, angle guards, wall opening frames, floor plate, steel grating, and miscellaneous support and anchor items.

Design and fabrication shall be in accordance with AISC Specifications. Materials shall be new and conform to ASTM A-36.

DIVISION 6 - WOOD AND PLASTICS

None Required

DIVISION 7 - THERMAL AND MOISTURE PROTECTION

Section 1 - Flashing and Sheet Metal

All necessary sheet metal and flashing work shall be .032 inches thick aluminum alloy 3003-H14. Finish shall be baked enamel of a color matching the adjoining cement asbestos siding.

Section 2 - Caulking and Sealants

All joints shall be properly caulked with elastomeric sealants as manufactured by Dap, Inc., or equal. Type shall be as recommended by the manufacturer for each intended use.

DIVISION 8 - DOORS AND WINDOWS

Section 1 - Hollow Meta1 Doors and Frames

All hinged personnel doors and frames shall be formed of No. $16 \mathrm{gage}$ cold rolled stretcher-leveled sheet steel as fabricated by Ceco Steel Co. or an approved equal. Doors shall be flush panel with insulation core.

Fire resistive doors and frames shall bear the proper Underwriters' Laboratory label.

\section{Section 2 - Rolling (Ro11-up) Stee1 Doors}

All roll-up doors shall be standard items as manufactured by the Apton Metal Products Corp., or equal. Curtains shall have flat interlocking galvanized steel slats with polyurethane filler inserts. Doors shall be furnished with neoprene jamb seals, weather stripped guides, hood baffles and astragals.

Doors less than $100 \mathrm{sq}$. ft. In area shall be manually chain operated. Doors exceeding $100 \mathrm{sq}$. ft. in area shall be motor operated with a safety edge bottom bar. 


\section{Section 3 - Metal Windows}

Interior windows shall consist of fixed glass set with neoprene gaskets into extruded aluminum store front type frames as manufactured by Kawneer, Inc., or equal.

\section{Section 4 - Finish Hardware}

Finish hardware including latchsets, locksets, hinges, closers, thresholds, flush bolts, door holders, and all necessary items shall be heavy duty as manufactured by Sargent and Company, or equal. Exposed surfaces of hardware shall have a finish as selected.

Weather stripping sound seals shall be as manufactured by Zero Weatherstripping Co., Inc., or equal.

\section{Section 6 - Glazing}

Glazing for all windows shall be $1 / 4$ inch clear tempered float glass. Neoprene gaskets shall be used for setting of glass.

All glass shall be as manufactured by a nationally recognized major glass manufacturer.

DIVISION 9 - FINISHES

Section 1 - Metal Studs

Metal studs shall be non-bearing screwable type 1-5/8 and 3-5/8 inches, 20 gage, punched for utlity lines, complete with top and bottom runners.

All lightgage metal framing shall be similar and equal to those manufactured by U.S. Gypsum Company .

\section{Section 2 - Gypsum Board (Dry-Wal1)}

The complete installation of gypsum board shall include attaching $5 / 8$ inch tapered edge type S.W. to metal studs with self tapping screw fasteners, metal corner beads, metal edge trim, and finishing of joints with joint compound and reinforcing tape. Materials and installation methods shall be similar and equal to those of U.S. Gypsum.

\section{Section 3 - Acoustical Ceiling Panels}

Acoustical ceiling panels shall consist of 2 inch thick rockwool acoustical panels fastened directly to the underside of the existing steel roof deck with screws and load spreading washers. Panels shall be cut and shaped around existing pipes, ducts, and equipment as required. 


\section{Section 4 - Painting}

Except as excluded herein, all new surfaces of the building shall be properly prepared, primed, and finished including but not limited to floors, walls, doors, cellings, equipment, piping, hangers, conduits, grilles and miscellaneous exposed materials.

Acoustical celling grid and panels

Factory fabricated mechanical and electrical equipment

The following items shall be factory primed and shall receive undercoats and finish coats as required:

Hollow metal doors, frames and windows

Vertical 1 ift doors

Rolling doors

Steel stairs, platforms, catwalks, raflings and ladders

Exposed portions of metal floor deck

The following surfaces shall not be painted but shall receive one coat of clear stlicone sealer:

All concrete floors (except Battery Room), curbs and walls.

Paints, primers and finishes shall be ready-mixed and equal to first line products manufactured by:

Sinclair Paint Co.

Devoe and Reynolds, In c.

Pratt and Lambert, Inc.

E. I. DuPont de Nemours and Co.

Rust-0leum Corporation

Glidden Company

Benjamin Moore and Co.

Surfaces shall be prepared and paints shall be applied in strict accordance with the manufacturer's recomendations. Colors shall be selected prior to application.

$\underline{\text { Painting Schedule }}$

All metal doors, frames and windows :
Factory primer

Two coats high gloss Alkyd Enamel 
Painting Schedule

Exposed structura1 steel and miscellaneous metal

Factory primer

Two coats high gloss Alkyd Ename1

Gypsum board:

1 coat Alkyd Primer Sealer

2 coats semi-gloss Alkyd Enamel

Electric \& mechanical equipment

2 coats Red Lead Primer

(without manufacturer's finish):

1 coat quick dry Alkyd Enamel

Battery room floor

2 coats Synthetic Floor Ename1

Contents and flow of all piping shall be indicated by adhesive identification and flow markers.

DIVISION 10 - SPECIALTIES

Not required.

DIVISION 11 - EQUIPMENT

Section 1. - Heat Exchangers and Air Coolers

The following heat exchangers and air coolers shall be provided:

Helium/Dowtherm G Heat Exchanger

Duty:

Function:

Type :

Tube Side

Helium flow:

Design pressure:

Design temperature:

Material:

Maximum Pressure drop:

Shell Side

Dowtherm $G$ flow:

Design pressure:

Design temperature:

Material:

Maximum pressure drop:
$79 \times 10^{6} \mathrm{BTU} / \mathrm{hr}$

To cool helium from $588.1^{\circ} \mathrm{F}$ to $576^{\circ} \mathrm{F}$ Horizontal she11 and tube

$1393 \mathrm{lbs} / \mathrm{sec}$

1635 psig

$650^{\circ} \mathrm{F}$

$\mathrm{SA}-210 \mathrm{Gr} \cdot \mathrm{Al}$

6 psi
$3450 \mathrm{gpm}$

150 psig

$650^{\circ} \mathrm{F}$

SA - 516 Gr. 70

3 psi 
Dowtherm G/Air Cooler

Duty:

Function:

Design pressure:

Design temperature:

Material:

Maximum pressure drop:

Cooling Water/Air Cooler

Duty:

Function:

Design pressure:

Design temperature:

Material:

Maximum pressure drop:
$79 \times 10^{6} \mathrm{BTU} / \mathrm{hr}$

To coo1 $3450 \mathrm{gpm}$ of Dowtherm G from $400^{\circ} \mathrm{F}$ to $300^{\circ} \mathrm{F}$

150 psig

$650^{\circ} \mathrm{F}$

Carbon steel

12 psi

Section 2 - Pumps

$10 \times 10^{6} \mathrm{BTU} / \mathrm{hr}$

To cool $1200 \mathrm{gpm}$ of cooling water from $117^{\circ} \mathrm{F}$ to $95^{\circ} \mathrm{F}$

60 psig

$150^{\circ} \mathrm{F}$

Carbon steel

6.0 psi

The following pumps shall be provided:

Dowtherm G Pumps (2)

Type :

Capacity:

Total head:

Design temperature:

Design pressure:

Motor HP:

Housing

Impe11er

Shaft/Sleeve

Dowtherm G Drain Pump

Type :

Capacity:

Total head:

Design temperature:

Design pressure:

Motor HP:

Material of construction
Centrifugal electrical motor

driven, base plate mounted $3450 \mathrm{~g} \mathrm{pm}$

$30 \mathrm{psi}$

$650^{\circ} \mathrm{F}$

150 psig

100

Carbon steel

Carbon steel

Stainless steel

Positive displacement, electrical motor driven, base plate mounted, complete with pressure safety valve $20 \mathrm{~g} \mathrm{pm}$

$25 \mathrm{psi}$

$200^{\circ} \mathrm{F}$

150 psig

$1 / 2$

Carbon steel 
Cooling Water Circulating Pumps (2)

Type:

Capacity:

Total head:

Design Temperature:

Design Pressure:

Motor HP:

Material of construction:

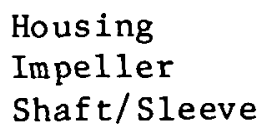

Centrifugal, electrical motor

driven, base plate mounted

$1200 \mathrm{gpm}$

$52 \mathrm{psi}$

$150^{\circ} \mathrm{F}$

60 psig

60

Carbon steel

Carbon steel

Stainless steel

Section 3 -Vessels and Tanks

The following vessels and tanks shall be provided:

Dowtherm G Storage Tank

Type:

Size:

Capacity:

Design pressure:

Design temperature:

Material of construction:
Horizontal

$6 \mathrm{ft}-6$ in dia $\times 14 \mathrm{ft}-0$ in long 3500 gallons

50 psig

$150^{\circ} \mathrm{F}$

Carbon steel

Cooling Water Expansion Tank

Type:

Size:

Capacity:

Design pressure:

Design temperature:

Material of construction:
Horizontal

$3 \mathrm{f} \mathrm{t}-6$ in. dia. $\times 7 \mathrm{ft}-0$ in. long 500 gallon's

75 psig

$150^{\circ} \mathrm{F}$

Carbon steel

High Purity Water Storage Tank (Existing)

Type:

Size:

Capacity:

Design pressure:

Design temperature:

Material of construction:
Vertical

$4 \mathrm{ft}-6$ in. dia. $x 9$ ft-0 in. long 1000 gallons

50 psig

Ambient

Stainless steel

Gaseous Helium Storage Bottles (48)

Type :

Size:

Capacity:

Pressure rating:

Material of construction:
Horizontal, cylindrical

18. : in. OD $\times 36 \mathrm{ft}-0$ in. long

$44.7 \mathrm{cu}$. ft. each (2145 cu. ft. total) 3500 psig

Carbon steel 
Gaseous Nitrogen Storage Bottles (10)

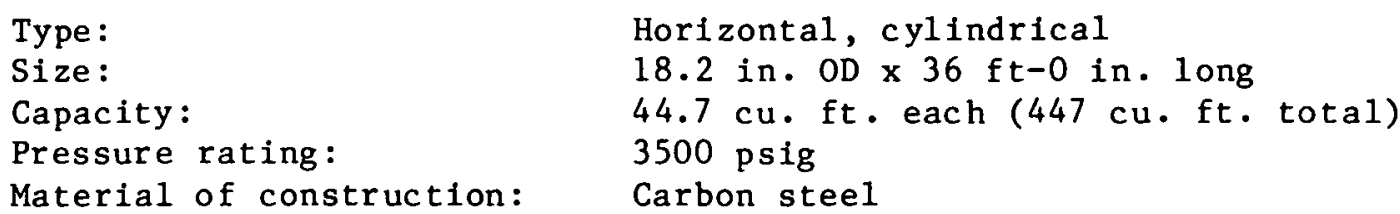

Section 4 - Packaged Unit and Special Equipment

Ammonium Hydroxide Injection Package

Package shall consist of a tank, injection pump, necessary piping valves and instrumentation.

Capacity: $\quad 5 \mathrm{gph}$

Hydrazine Injection Package

Package shall consist of a tank, injection pump, necessary piping, valves and instrumentation.

$$
\text { Capacity: } \quad 5 \mathrm{gph}
$$

\section{Compressed Air Unit}

Package shall include two compressors, $30 \mathrm{HP}$ each, dual tower type desiccant absorber, and a receiver. Intercoolers and aftercoolers shall be water cooled units. Package shall be fully automatic controlled.

$$
\begin{array}{ll}
\text { Capacity: } & 100 \mathrm{ACFM}, \text { each } \\
\text { Discharge pressure: } & 125 \mathrm{psig}
\end{array}
$$

Vacuum Pump

Vacuum pump shall be capable of evacuating air or helium and water vapor from test vessel at atmospheric pressure to abs. vacuum of $1 \mathrm{~mm}$ $\mathrm{Hg}$, and exhaust to atmosphere.

$$
\begin{array}{ll}
\text { Capacity: } & 60 \mathrm{cfm} \\
\text { Driver: } & 3 \mathrm{HP} \text { electric motor }
\end{array}
$$

Buffer Helium Compressor Package

Package shall include a precooler, two diaphragm compressors and all necessary piping, valves, instrumentation and control. Motors $3 \mathrm{HP}$ each.
Capacity:
12 ACFM
Inlet pressure:
Outlet pressure: 
Helium Compressor Package

Package shall include one single stage compressor with $25 \mathrm{HP}$ motor, one two stage compressor with 50HP motor, all necessary intercooler and aftercoolers, piping, valves, instrumentation and control.

$\begin{array}{ll}\text { Type: } & \text { Diaphragm } \\ \text { Capacity: } & \text { Variable } \\ \text { Inlet pressure: } & 1450 \text { psig to atmospheric } \\ \text { Outlet pressure: } & 3000 \text { psig }\end{array}$

Helium Dryer

Unit shall be capable of drying gaseous helium at 3000 psig to dew point of $40^{\circ} \mathrm{F}$. Regeneration shall be manually controlled.

Type :

Capacity:

Design pressure:
Dual tower, desiccant absorber. Electric regeneration.

200 SCFM

3000 psig

\section{Section 5 - Circulator Test Vessel and Internals}

The circulator vessel shall be a horizontally mounted cylindrical carbon steel vessel with an elliptical head on one end and a flanged opening at the other end. The flanged opening shall be designed to accommodate a bolted circulator and bearing assembly. Two large nozzles provide for discharge and return of the helium. Additional nozzles shall provide for instrumentation penetrations and control functions.

Design pressure:

Design temperature:

Size:

OD

T-Flange Face Heads

Wall Thickness

Overall Length

Circulator Flange ID

Penetration:

$$
\begin{aligned}
& \text { 1-Helium Outlet } \\
& \text { 1-Helium Inlet } \\
& \text { 1-Instrumentation } \\
& \text { 3-Instrumentation } \\
& \text { 1-Drain Line } \\
& \text { 1-Gas Jet Supply }
\end{aligned}
$$

1635 psig (int.) $650^{\circ} \mathrm{F}$

11 feet 3 inches

23 feet 6 inches

2:1 semi elliptical \& flanged cover 6.08 inches

30 feet 1 inch

71 inches
56 inches ID (beveled for welding)
50 inches ID (beveled for welding)
6 inches 1500 flanged
4 inches 1500 flanged
2 inches 1500 flanged
1 inch 1500 flanged 
Insulation:

External

See Division 13

Internal

To be furnished and installed by GAC

34 Studs

68 Studs

$1 / 2$ inch (for internal insulation support)

$3 / 8$ inch (for internal insulation support)

Internals :

The vessel shall be divided into inlet and outlet compartments, by means of an internal flanged and dished head.

A 36 inch duct conveys return gas from the inlet compartment to the inlet of the circulator.

Supports shall be provided to mount the diffuser at the flanged cover.

Materials:

Vessel shell

SA-516-70

Vessel Heads

$\mathrm{SA}-516-70$

Vessel Supports

$\mathrm{SA}-285 \mathrm{C}$ and $\mathrm{SA}-36$

Code Certificates and Stamp Required:

ASME Boiler and Pressure Vessel Code Section VIII, Division 1.

Testing:

Witnessed hydrostatic test and helium leak test.

\section{DIVISION 12 - FURNISHINGS}

Not required

DIVISION 13 - SPECIAL CONSTRUCTION

Section 1 - Acoustic Insulation of the Circulator Vessel

Double acoustic insulation shall be installed. The inner insulation layer shall be 3 inches of mineral wool of $6 \mathrm{lbs} / \mathrm{cu}$. ft. density. Securement shall be by bands applied as follows:

On cylindrical shell

Circumferential bands shall be on 12 inch centers, machine stretched and clamped in place during tension. Two crimpseals shall be used to secure each band. 
On head

Radial bands shall emanate from a floating ring fabricated from a $3 / 16$ inch OD metal rod and positioned concentric with the centerline of the head. These radial bands shall be held in place by anchor bands. These anchor bands shall be triple bands attached around the shell 24 inches from the vessel head.

Potential noise leaks around nozzles shall be sealed with mastic cement.

The outer jacket of the cylindrical portion of the vessel shall be fabricated from $26 \mathrm{Ga}$ galv. steel and held in place by 1 inch wide stainless steel bands on 12 inch centers. On heads and on vessel wall penetrations, where a jacket would be impractical, the jacket shall be made of Muffi-1ag, or equal trowelled on to a minimum thickness of $1 / 8$ inch

The outer insulation layer shall be 2 inches of fibre glass of $6 \mathrm{lbs} / \mathrm{cu}$. ft. density. Securement shall be by bands applied as on the first layer except that the anchor bands securing the radial head bands shall be double.

Potential noise leaks around nozzles shall be sealed with mastic cement.

The outer jacket of the cylindrical portion of the vessel shall be fabricated from Muff1-lag or equal held in place by 1 inch wide stainless steel bands on 12 inch centers. The outer jacket of the head shall be Muffi-lag as per previous layer.

\section{Section 2 - Acoustic Insulation of Pipe System}

Acoustic insulation shall be applied in two layers to the helium loop piping and the depressurization system piping.

The inner insulation layer shall be 3 inches of mineral wool of $6 \mathrm{lbs} / \mathrm{cu}$. $\mathrm{ft}$. min density. Securement shall be by bands on 12 inch centers, machine stretched and clamped in place durlng tension. Two crimpseals shall be used to secure each band. Potential noise leaks shall be sealed with mastic cement. The jacket shall be made from 26 ga galvanized steel welded in place by 1 inch stainless steel bands on 12 inch centers. On portions of the pipes and valves where use of a metal jacket is impractical, apply minimum $1 / 8$ inch thick Muff1-lag.

The outer insulation layer shall be 2 inches of fibre glass of $61 \mathrm{bs} / \mathrm{cu}$. ft. minimum density. Band and secure as previously. The outer jacket shall be made of Muffl-jack secured by 1 inch stainless steel bands on 12 inch centers. On portions of the pipes and valves where use of this jacket is impractical, apply minimum $1 / 8$ inch thick Muffl-lag.

Notes for insulation installation:

Insulation shall be fabricated or preformed to fit the contour of equipment shells and heads. 
All joints shall be tightly butted. V-shaped voids between joints are not acceptable.

Staggered joint construction shall be used. Joints of one layer shall not coincide with joints of another layer.

Removable insulation covers shall be fabricated for manholes and like items as indicated on equipment drawings. The insulation and $f$ inish shall form an integral unit, capable of removal and replacement without damage to the insulation cover of adjacent insulation.

Muff1-lag and Muff1-jack available from Childers Products Company, P.O. Box 22228, Beackwood, Ohio 44122.

DIVISION 14 - CONVEYING SYSTEMS

Not required.

DIVISION 15 - MECHANICAL

Section 1-Plumbing

This section covers floor drains, piping accessories, installation, cleaning, and testing.

Floor Drains: $\quad$ Zurn No. $415 \mathrm{ZN}$ cast iron body with nickel bronze top, Type B strainer - four inch pipe size.

The piping materials for the waste and vent piping shall be as follows:

All waste and vent lines 3 inches and larger to a point 5 foot 0 inches outside the building wall shall be cast iron.

Waste Piping: . $\frac{3 \text { inches and larger: Extra heavy cast iron bel1 }}{\text { and spigot; } \Lambda S \Lambda-\Lambda-0.1 .}$

Waste Fittings: $\quad 3$ inches and larger: Extra heavy cast iron bell and spigot; ASA-440.1.

All waste and vent 1 ines 2-1/2 inches and smaller above ground shall be galvanized steel.

Piping :

2-1/2 inches and smaller: Schedule 40 galvanized welded steel pipe; ASTM-A120. 
Waste Fittings:

Vent Fittings:
2-1/2 inches and smaller: Black cast iron recess screwed drainage type; ASA-B 16.12 .

$2-1 / 2$ inches and smaller: $1501 \mathrm{~b}$. galvanized malleable iron banded screwed ASA-B16.3.

\section{Section 2 - Piping}

The piping materials for the helium loop, buffer helium system, helium storage and supply system, depressurization system and 2400 psi nitrogen system shall be as follows:

Piping :

Fittings:

Flanges :

Gaskets :

Bolting :

Valves:
24 inches and smaller: ASTM A $106 \mathrm{Gr}$. B

3 inches and under: Schedule 160

4 inches thru 10 inches: Schedule 120

48 inches ID thru 56 ID inches: ASTM A 516, GR 70

48 inches I.D.: Min. Thickness 2-1/2 inches

50 inches I.D.: Min. Thickness $2-1 / 2$ inches

56 inches: Min. Thickness 2-13/16 inches

2 inch and smaller: ASTM A-105, 6000 1b. S.W.

2-1/2 inches thru 10 inches: seamless butt weld ASTM A 234, Gr. WPB thickness to match pipe

48 inches thru 56 inches: we 1 ded, $100 \%$ radiographed thickness to match pipe, ASTM 516, GR 70 .

ASTM A 105, Bored to match pipe

1 inch thru 24 inches: 1500 lb. weld neck, R.J.

48 inches: Special "0" ring groove

1 inch thru 24 inches: Soft steel oval rings

- Over 24 inches: Self energizing " 0 " ring

ASTM A 193, Gr. B7

ASTM A 194; Gr. 2H.

Gate: all sizes 1500 1b., R.J. 
The piping materials for the Dowtherm G System, and vacuum system shall be as follows:

Piping :

Carbon stee1, ASTM A53 GRB

$1 / 2$ inch to $1-1 / 2$ inches: $\mathrm{XS}$

2 inches only: std. wt.

$\frac{3 \text { inches to } 16 \text { inches: ERW st } 1 \text { API-5L Gr. B std. }}{\text { wt. }}$

Fitting :

$1 / 2$ inch to $1-1 / 2$ inches: 3000 1b. SW CS ASTM A105

2 inches to 16 inches: St 1 buttwelding fittings

ASTM A234 gr WPB, std wt.

Flanges:

150 1b. st1 RF ASTM A105

$1 / 2$ inch to $1-1 / 2$ inches: socketweld ( $\mathrm{SX}$ bore)

2 inches to 16 inches: weld neck (std wt. bore)

Gaskets :

$\frac{1 / 2 \text { inch to } 16 \text { inches: }}{1 / 8 \text { inch thick. }}$ comp. asb. JM60 $1501 \mathrm{~b}$. ,

Bolting :

$1 / 2$ inch to 10 inches: ASTM A193 gr. B7M studs 2 hexnuts ASTM A194 Gr. $2 \mathrm{H}$

Valves :

Gate

$1 / 2$ inch to $1-1 / 2$ inches: $8001 \mathrm{~b}$. st $1 \mathrm{SW}$

2 inches to 16 inches: $1501 \mathrm{~b}$. st $1 \mathrm{RF}$.

Check

$1 / 2$ inch to $1-1 / 2$ inches: $8001 \mathrm{~b}$. st $1 \mathrm{SW}$, horiz lift

2 inches to 16 inches: $1501 \mathrm{~b}$. st $1 \mathrm{RF}$, swing

The piping materials for High Purity Water System shall be as follows:

Piping :

Stainless.Stec1, ASTM A312 Gr TP304

$1 / 2$ inch to 2 inches: Sch. $40 \mathrm{~S}$ (T\&C)

3 inches to 8 inches: $\mathrm{Sch}$. 5S

Fittings :

$1 / 2$ inch to 2 inches: 2000 1b. Scrd ASTM Al82 Gr TP304

3 inches to 8 inches: Buttweld, ASTM A234 GR TP304

Flanges :

150 1b. RF ASTM A182 GR F304

$1 / 2$ 1nch to 2 inches: scrd

3 inches to 8 inches: S1ip-on 
Gaskets :

Bolting:

Valves :

$1 / 16$ inch thick Comp. Asb Ring JM60 or Equal.

ASTM A307 Gr B Hvy Hex Head Mach Bolt w/Hvy Hexnut

Gate

$1 / 2$ inch to $1-1 / 2$ inches: 150 1b. 316SS, Scrd.

2 inches to 8 inches: 150 lb. 316SS, RF

Globe

$1 / 2$ inch to $1-1 / 2$ inches: $1501 \mathrm{~b} .316 \mathrm{SS}$, Scrd.

2 inches to 8 inches: 150 lb. $316 \mathrm{SS}, \mathrm{RF}$

Check

$1 / 2$ inch to $1-1 / 2$ inches: $1501 \mathrm{~b}$. 316sS Scrd, Swing

2 inches to 8 inches: 150 lb. $316 \mathrm{sS}$, FR, Wafer Style

The piping materials for the Cooling Water System shall be as follows:

Piping :

Fittings :

Flanges :

Gaskets :

Bolting :

Valves:
$1 / 2$ inch to 2 inches: XS ( $T \& C$ ) Carbon stl ASTM A53, galvanized

3 inches to 10 inches: ERW stl ASTM A53 std. wt.

$\frac{1 / 2 \text { inch to } 2 \text { inches: }}{\text { galvanized }} 3001 \mathrm{~b}$. MI scrd ASTM Al97,

3 inches to 10 inches: St 1 butt welding ASTM A234 Gr. WPB, std. wt.

150 1b. stl FF ASTM A105

$1 / 2$ inch to $1-1 / 2$ inches: scrd

2 inches to 10 inches: weld neck (std wt. bore)

Comp Asb $\mathrm{M} 60$

All sizes 150 1b. $1 / 8$ inch thk full face

All sizes, hex head galv . machine bolts ASTM A307 $\mathrm{Gr}$. B. for $150 \mathrm{lb}$. flanges

Gate

$1 / 2$ inch to $1-1 / 2$ inches: $2001 \mathrm{~b}$. scrd bronze

2 inch to 10 inches: $1251 \mathrm{~b}$. PSF $1 \mathrm{BBT}$

Globe

$1 / 2$ inch to $1-1 / 2$ inches: $2001 \mathrm{~b}$. scrd bronze

2 inches to 4 inches: 125 b. FF $1 \mathrm{BBT}$

Check

$1 / 2$ inch to $1-1 / 2$ inches: 200 lb. scrd bronze, swing

2 inch to 10 inches: $125 \mathrm{lb}$. FF.CI split disc . 
The plant air and 150 psi nitrogen systems piping materials shall be as follows:

Piping :

Screwed Fittings:

Welding Fittings:

Flanges :

Gaskets :

Bolting :

Valves:

Hose Couplings:

Piping Specialties: Condensate Trap
4 inches and smaller: Black seamless steel pipe; ASTM - A53, Grade "B", standard weight

2 inches and smaller: 300 1b. biack malleable iron, banded, ANSI - B16.19.

2-1/2 inches and 1arger: Standard weight seamless steel, ASTM - A234, Grade "WPB".

2 inches and smaller: $1501 \mathrm{~b}$. forged steel, screwed, FF, ASTM - A105, Dimensions to ANSI - B16.5.

2-1/2 inches and larger: $150 \mathrm{lb}$. forged steel, slip- on, FF, ASTM, Al05, dimensions to ANSI - B16.5.

Weld-neck flanges may be used against fittings when it is impractical to use slip-on flanges.

All sizes: $1 / 16$ inch thick compressed asbestos ANSI - B16.21, full-face with bolt holes.

All sizes: Carbon steel square head machine bolt, with one semi-finished heavy hex nut, ASTM - A307, Grade "B".

2 inches and smaller:

Gate

2001 b bronze, screwed-end, rising stem, union bonnet. Crane $\$ 424$ or approved equal.

Globe

4001 b. bronze, screwed-end, rising stem, union bonnet with composition disc. Crane \#130 or approved equal.

Check

$4001 \mathrm{~b}$. bronze, screwed-end, horizontal lift, union cap with bronze disc, Crane $\$ 72$ or approved equal. 2-1/2 inches and larger.

All sizes:

Brass, quick-connect/disconnect type, full-flow coupling unit, Snaftite style " $H$ " or approved equal.

250 psi, cast iron, $1 / 2$ inch screwed, Armstrong 1-LD, or approved equal. 
Section 4 - Heating, Ventilating and Air Conditioning

This section covers all heating and ventilating equipment, ductwork, installation, cleaning and testing.

\section{Wall Exhauster}

Wall mounted exhauster shall be direct drive and factory fabricated of aluminum backwardly curved centrifugal wheel, complete with felt edged weighted matching backdraft damper and disconnect switch. Unit shall be manufactured by Loren Cook Co. or approved equal.

$\begin{array}{lrrrrrr}\text { Location } & \frac{\text { CFM }}{\text { Mezzanine }} & \frac{\text { S.P. "W.G. }}{1,500} & \frac{\text { Motor }}{1 / 8} & \frac{\text { RPM }}{1 / 4 \mathrm{HP}} & \frac{\text { Mode } 1}{140} & \frac{1}{5 \mathrm{C} 11 \mathrm{~W}} \\ \text { Battery Room } & 250 & 1 / 4 & 1 / 40 \mathrm{HP} & 1050 & 9 \mathrm{ClOW}\end{array}$

Supply Fan

Unit shall be a direct drive in-line model and constructed of all aluminum both inside and outside with airfoil blades, statically and dynamically balanced and with a factory installed disconnect switch. Unit shall be rated for $4700 \mathrm{CFM}, 1 / 2$ inch WG, $1140 \mathrm{RPM}, 1-1 / 2 \mathrm{HP}$ as manufactured by Roren Cook Co. Model 20CV11D or approved equal.

\section{Electric Duct Heater}

Electric duct heater shall have a capacity of $9 \mathrm{~kW}, 3$ stages, $480 \mathrm{VAC}, 3$ phase, $60 \mathrm{~Hz}$, complete with overcurrent protective circuit breakers, safety contactors and manual reset, as manufactured by INDEE Co. model QUA with option $E$ or approved equal.

\section{Electric Unit Heaters}

Electric unit heaters shall be of the suspended horizontal discharge type with direct-driven propeller fan. The units shall be complete, including heating element, vibration isolated motor mounts, factory finished casing, adjustable air deflectors, fan guards, streamlined air inlet rings, and built in thermostat. Unit shall be $4 \mathrm{~kW} 480 \mathrm{VAC}, 3$ phase, $60 \mathrm{~Hz}$ model LUH-04-07 as manufactured by Chromalox or approved equal.

\section{Sheet Metal Ductwork and Accessories}

Sheet metal ductwork shall be constructed of galvanized steel sheets. Square elbows shall be provided with double wall turning vanes. Ducts and supports shall be fabricated in conformance with SMACNA Low Velocity Duct Construction Standards.

Flexible Duct Connections - Where sheet metal connections are made to equipment, noncombustible flexible connection of durolon or other approved noncombustible material approximately 6 inches in width shall be provided. 
Registers and grilles shall be factory fabricated of steel or aluminum and shall distribute the quantity of air specified evenly over the space intended without causing noticeable drafts over $50 \mathrm{fpm}$ in occupied zones.

\section{Section 5 - Fire Protection}

This section covers the Halon 1301 system, portable hand fire extinguishers, installation, cleaning, and testing.

\section{Halon 1301 System}

The system is designed to provide a specific volume concentration of extinguishing agent with discharge time not to exceed 10 seconds. The system shall be capable of meeting the performance parameters in the National Fire Protection Association Standard 12A.

\begin{tabular}{|c|c|c|c|c|}
\hline Hazard Title & $\begin{array}{l}\text { Total Flood } \\
\text { Volume }\end{array}$ & $\begin{array}{c}\text { Method of } \\
\text { Application }\end{array}$ & $\begin{array}{c}\text { Design } \\
\text { Concentration } \\
\end{array}$ & $\begin{array}{l}\text { Pounds } \\
\text { of Halon }\end{array}$ \\
\hline Control Room Complex & $12096 \mathrm{cu} \mathrm{ft}$ & $\begin{array}{l}\text { Total } \\
\text { Flooding }\end{array}$ & $6 \%$ & 307 \\
\hline $\begin{array}{l}\text { Motor Controller } \\
\text { Module }\end{array}$ & $2772 \mathrm{cu} \mathrm{ft}$ & $\begin{array}{l}\text { Total } \\
\text { Flooding }\end{array}$ & $5 \%$ & 110 \\
\hline Pony Motor Controller & $126 \mathrm{cu} \mathrm{ft}$ & $\begin{array}{l}\text { Total } \\
\text { Flooding }\end{array}$ & $5 \%$ & 5 \\
\hline
\end{tabular}

The extinguishing system for the control room complex shall include the following components:

Agent Storage Cylinders - Two (2) 200 1b. steel cylinders to be manufactured to the requirements of Department of Transportation Spec. 48A, for compressed gas, and have internal neck threads for cylinder valve connection.

Cylinder Valves - Valves to be constructed of corrosion resistant materials and high flow rate enabling system to be discharged in ten seconds. Valves to be actuated electronically.

Discharge Nozzles - chrome plated brass or 303 Stainless Steel. The nozzle discharge pattern shall be a 120 degree full cone for all sizes. Nozzles shall be permanently marked for identification.

The Halon 1301 system shall be designed to operate with manual pull boxes and cross zoned smoke detection actuation.

Smoke Detectors shall be arranged in a cross-zoned configuration and shall activate the pre-discharge alarm and discharge Halon 1301. 
Smoke Detectors shall be "spot type" and "restorable" and shall be suitable for use with the specified hazards. Location and spacing of the detectors shall be in accordance with the manufacturers recommendations.

Manual Pull Station - The manual pull station shall be contained within a cast metal housing and have a dual action release configuration to prevent accidental discharge. The housing shall incorporate a tamperproof screw to prevent unauthorized access to the reset mechanism. The device shall have an operating voltage of 120 volts A.C. and be mountable on a standard four inch junction box. The Unit shall be Underwriter Laboratory Listed or Factory Mutual approved.

Electric Control Panel capable of providing supervision of the following functions :

Input Power

Manual Pul1 Station

Initiator

Ala rm Bell

Time Delay

Trouble and Alarm Silence Switch

Alarm bell and red rotating beacon

The extinguishing system for the main motor controller module, the pony motor controller and cable spreading area shall include the following components:

Agent Storage Cylinder - Steel cylinders to be manufactured to the requirements of Department of Transport Spec. 48A, for compressed gas, and have internal neck threads for cylinder valve connection. The following cylinders required:

For the Main Motor Controller Module ten (10) 5 1b., and six (6) 10 1b. cylinders, each filled with Halon 1301 and super pressurized with dry nitrogen to a pressure of $360 \mathrm{psig}( \pm 5 \%)$ at $70^{\circ} \mathrm{F}$.

For the Pony Motor Controller, and cable spreading area the cylinders shall contain 51 b of Halon 1301 and super pressurized with. dry nitrogen to a pressure of 360 psig ( $\pm 5 \%$ ) at $70^{\circ} \mathrm{F}$.

Flexible Connector - Eighteen (18) $1 / 2$ inch by 12 inches long flexible connections, connectors will be stainless steel with wire braid cover and a teflon liner, each end with $1 / 2$ inch NPT male threads.

Smoke Detectors shall be "spot type" and "restorable" and shall be suitable for use with the specified hazards. Location and spacing of the detectors shall be in accordance with the manufacturers recommendations.

Solenoid Release - Eighteen (18) 2 way normally closed explosion proof valves with the following characteristics:

24 volts D.C.

Orifice $5 / 6$ inch dia. 
Maximum operating pressure: 630 psig

Power consumption: 10 watts

Solenoid: Continuous duty

Material: Stainless steel body, neoprene plunger insert

Pressure Switch - Eighteen (18) required, NEMA 1 enclosure switch rating $5 \mathrm{amp}$ C $120 \mathrm{VAC}$.

Manual Releases - Eighteen (18) pilot operated discharge heads with handwheels.

\section{Portable Fire Extinguisher}

Portable fire extinguisher shall be in accordance with NFPA 10 , and of the dry chemical extinguisher type (potassium bicarbonate) with 20 lbs capacity and classification of $B \& C$.

DIVISION 16 ELECTRICAL AND INSTRUMENTATION AND CONTROL

Section 1 - Overhead Power Line

A $138 \mathrm{kV}$ overhead power line, required to connect the Helium Circulator Test Facility's $138 \mathrm{kV}$ switchyard to the existing local utility's $138 \mathrm{kV}$ transmission system, shall be designed and constructed in accordance with the State of California's General Order No. 95, covering the construction of 138 $\mathrm{kV}$ overhead power lines. It shall be built using the following types of material and equipment.

Load-Break Disconnect Switch

One pole top, load break, group operated disconnect switch meeting the following specifications.

Voltage Rating

Continuous current rating

Load Interrupting Rating

Basic Impulse Level

Number of Poles

Phase Spacing

Type of Break

Type of Mounting

Type of Operating Mechanism

Momemtary Rating

Type Swi.trh
$138 \mathrm{kV}$

1200 amperes

1200 amperes

$650 \mathrm{kV}$

3

8 feet, based on SF 6 switch Vertical

Horizontal-Top of Pole Structure

Manua1-Group

$61 \mathrm{kA}$

ITE SF6 load interrupter or equal 
Supporting Insulators:

$138 \mathrm{kV}$, Station Post with 5 inch Bolt Circle

\section{Overhead Conductor}

Size

Number of Aluminum Strands

Number of Steel Strands

Outside diameter of complete cable

Ultimate Strength Pounds

Ohms per mile resistance

Ohms per mile reactance

Conductor Spacing

Approximate Length

Overhead stranded steel ground wire

Outside diameter

Number of Steel Strands

Type of Steel Wire

Approximate Length
300 MCM ACSR

30

7

0.70 inches

15,430

0.311

0.77 for 14 foot spacing 14 feet

3,000 feet Type of insulators - both for use at dead ending towers and at line
towers:

Suspension insulators of the ball and socket type:

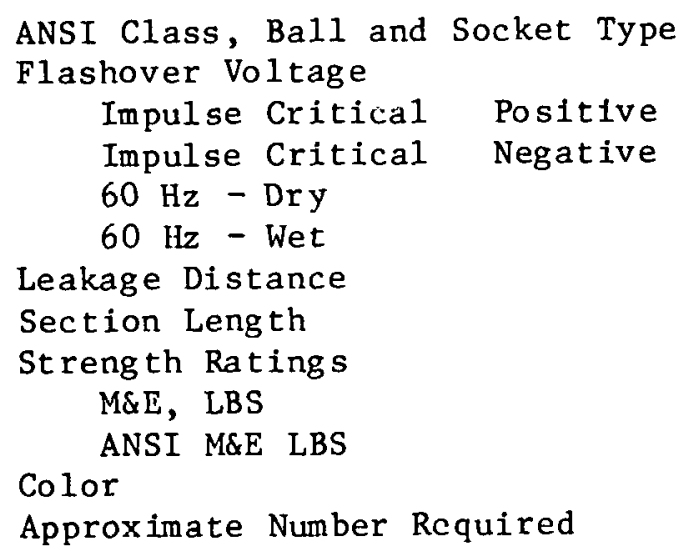

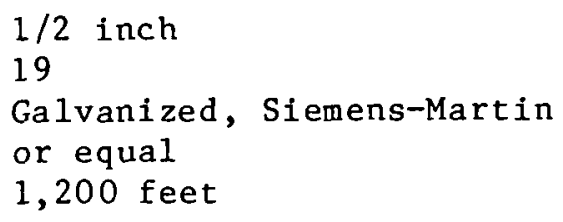


Type of overhead hardware at dead ending towers and at line towers.

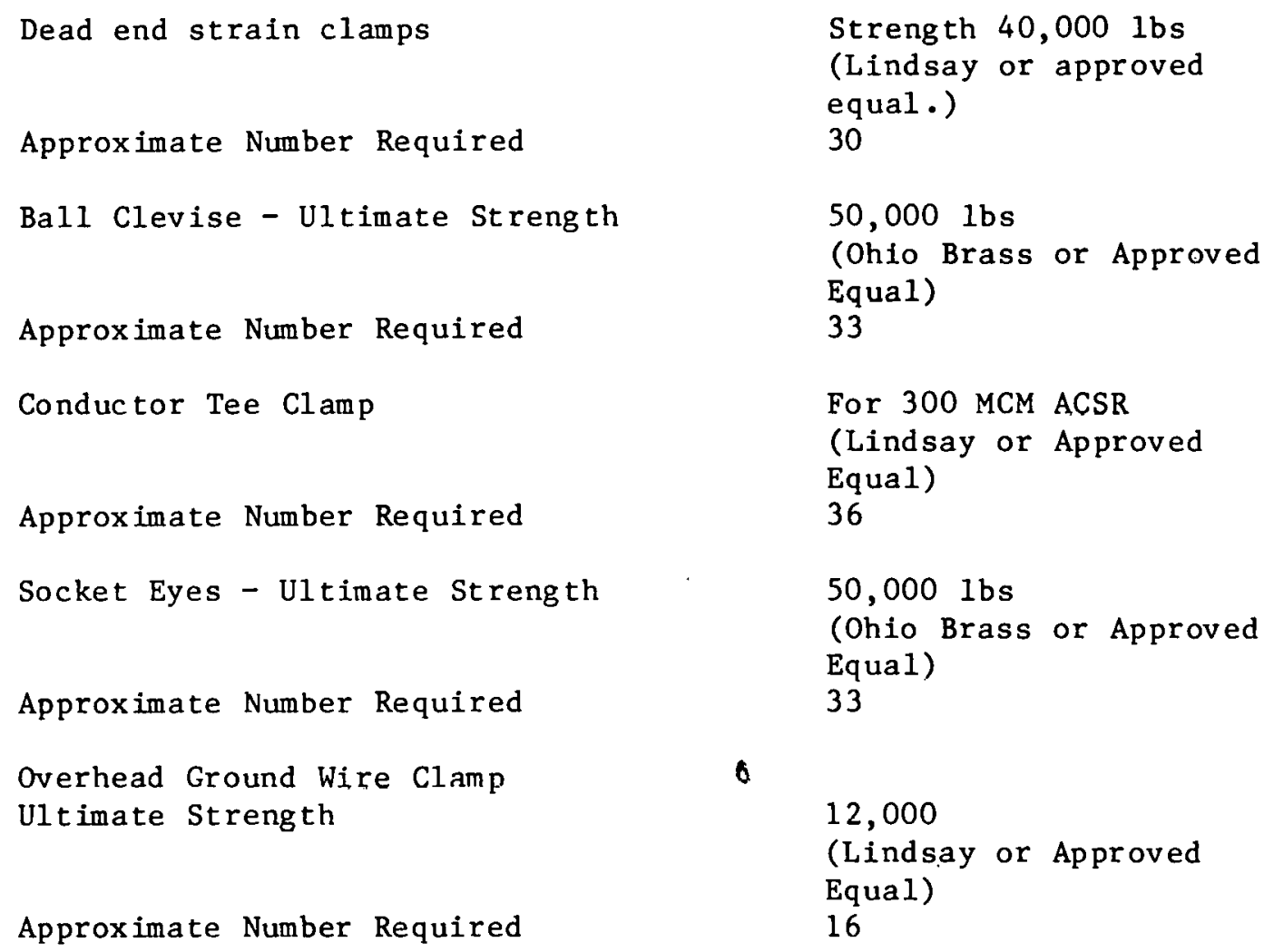

Type of Supporting Structures

"H" Frame construction arranged for a conductor spacing of 10 feet; using class "A" wooden treated power poles; wooden cross arms with galvanized steel cross arm braces and $5 / 8$ inch galvanized steel guying wire, for the required down guys, with an approved anchor.

Structure Spacing

Average spacing between "H" frame support structures - 350 feet. Six (6) $H$ Frame support structures required.

Conductor Tension

Maximum pulling tension in ACSR conductor - 50 percent of the conductor ultimate strength.

$\underline{\text { Transmission Line Tap }}$

Connection into the electric utility's $138 \mathrm{kV}$ transmission system shall be by means of an overhead manual group operated $138 \mathrm{kV}$ load break switch and a pole structure to which the electric utility's line can be dead ended. 
Section No. $2-138 \mathrm{kV}$ Incoming Disconnect Switch - at $138 \mathrm{kV} \mathrm{Switchyard}$

The incoming $138 \mathrm{kV}$ disconnect switch shall be a 3 pole, outdoor, manually group operated, pedestal mounted, vertical break type. It will be used as an isolating switch for the main incoming $138 \mathrm{kV}$ oll circuit breaker and sha11 be furnished in accordance with the latest NEMA and IEEE standards.

Disconnect switch continuous

current rating

Momentary current rating

Basic impulse leve1

Locking

Temperature rise

Interlocking

Supporting insulators

Phase spacing

Cable connectors

Grounding switch

Type continuous current rating

Cable connectors
1200 amps.

$61 \mathrm{kA}$.

$650 \mathrm{kV}$.

Positive closed position lock.

Not more than $30 \mathrm{C}$, over a $40 \mathrm{C}$ ambient

The group operated mechanism for the disconnect and grounding switches shall be interlocked.

$138 \mathrm{kV}$ station post type with a 5 inch bolt circlc.

8 feet.

For 300 MCM ACSR conductor.

3 pole, manua1, group operated.

600 amps.

For a 250 MCM bare stranded copper grounding cable.

Installation shall be in accordance with Drawing EE-102.

Section $3-138 \mathrm{kV}$ Disconnecting Switch for $138 \mathrm{kV}$ Bus Potential Transformers

The $138 \mathrm{kV}$ disconnecting switch for the $138 \mathrm{kV}$ bus potential transformers shall be a 3 pole, outdoor, manually group operated, pedestal mounted, vertical break type. It will be used to disconnect and to isolate the three bus potential transformers, as shown by Drawing Nos. EE-101. It shall be furnished in accordance with the latest NEMA, IEEE and ASA requirements for outdoor group operated disconnect switches. The disconnect switch shall have:
Continuous current rating
600 amperes
Momentary current rating
$40 \mathrm{kA}$ 
Basic impulse level

Locking

Supporting insulating

Operating mechanism

Supporting base

Temperature rise
$650 \mathrm{kV}$

Postive closed position lock

$138 \mathrm{kV}$ station post type, each with 5 inch bolt circle.

Group Manual

Galvanized steel.

Not more than $30^{\circ} \mathrm{C}$ over a $40^{\circ} \mathrm{C}$ ambient.

Section $4-138 \mathrm{kV}$, Outdoor, Base Mounted Potential Transformers

The $138 \mathrm{kV}$ outdoor, oil filled, potential transformers shall be designed, manufactured and tested in accordance with the applicable ANSI and NEMA standards for ANSI metering accuracy class, $60 \mathrm{~Hz}$, potential transfomers. They shall be rated and shall meet the following requirements:

Accuracy

Operating voltage

Voltage ratio

Secondary voltage

Overvoltage withstand

Temperature Rise

Basic impulse leve1

No. of potential transformers required

General Requirements
ANSI 0.3 class at standard burdens - W, X, M, Y, Z, ZZ. line to neutral $-80 \mathrm{kV}$.

$80 / 0.12 \mathrm{kV}-3$ - Potential transformers to be connected in wye to a $138 \mathrm{kV}$ wye connected power system.

120 volts - Wye.

$173 \%$ of normal for one minute operation under emergency conditions as required by ANSI Standard C57.13.

$55^{\circ} \mathrm{C}$ at $30^{\circ} \mathrm{C}$ ambient.

$650 \mathrm{kV}$.

3

Each potential transformer to be oil filled, outdoor type, base mounted, selfsupporting and to be furnished with a primary cable connection for No. 4/0 AWG, bare, stranded copper con- 
The ofl filled potential transformers will be installed outdoors on a stee 1 pedestal and will be used in the metering of a $138 \mathrm{kV}$ feeder circuit.

\section{Section 5-138 kV, Outdoor Base Mounted Current Transformers}

The $138 \mathrm{kV}$, outdoor, oil filled current transformers shall be designed, manufactured and tested in accordance with applicable ANSI and NEMA standards for ANSI metering accuracy class, $60 \mathrm{~Hz}$ current transformers. They shall be rated and shall meet the following requirements:

Accuracy - ANSI Metering Accuracy

Class (60 Hertz)

Rating

Operating voltage

Primary ampere rating

Secondary ampere rating

Rating factor

Thermal Rating

One second

Five seconds

Mechanical Rating (RMS Symmetrical)

Temperature rise

Bastc impulse level

Number of current transformers required

General Requirements:
0.3 class for $B-0.1, B-0.2$, $\mathrm{B}-0.3, \mathrm{~B}-1.0 \& \mathrm{~B}-2.0$ burden.

$138 \mathrm{kV} 60$ Hertz

160 amperes

5 amperes

1.5

65 times normal

29 times normal

85 times normal

$55^{\circ} \mathrm{C}$ at $30^{\circ} \mathrm{C}$ ambient

$650 \mathrm{kV}$

three (3)

Each current transformer to be oil filled, outdoor type, base mounted, selfsupporting and to be furnished with primary cable connector for No. 4/0 AWG, bare, stranded copper conductor and a secondary terminating box, arranged for 1-1/2 inch conduit entrance. 
The $138 \mathrm{kV}$ oil filled current transformers shall be installed outdoors on a steel pedestal and will be used in the metering of a $138 \mathrm{kV}$ feeder circuit.

\section{Section 6 - Outdoor Metering Equipment}

The outdoor metering equipment shall be furnished, mounted and wired to outgoing terminal blocks, on a steel instrument panel, housed in an outdoor, weatherproof steel cabinet, with a gasketed hinged door.

The metering equipment shall consist of the following:

One three phase watt hour meter arranged for semi flush mounting on the above steel instrument panel, to measure the watt hours of a $138 \mathrm{kV}$, three phase feeder line and operating with the following instrument trans formers.

$3-160 / 5$ ampere, outdoor $138 \mathrm{kV}$ pedestal mounted current transformers connected in wye.

3 - $80 \mathrm{kV} / 120$ volt outdoor, pedestal mounted potential transformers connected in wye in the $138 \mathrm{kV}$ three phase feeder line.

One A.C. recording, contact operated, strip-chart demand meter to totalize the impulses received from the above watt hour meter's 3 wire contact device for a coincident KW demand. This device to be furnished with a case suitable for semi flush mounting on the above steel instrument panel.

A panel mounted current and potential test block; consisting of three current elements and four potential elements; each back connected and mounted on the above instrument panel.

The required pressure type terminal blocks.

All the instrument and devices, as 1 isted above shall be mounted on the instrument panel and completely wired to the outgoing terminal blocks.

\section{Section 7 - Outdoor, Station Type, $120 \mathrm{kV}$ Lightning Arresters}

The outdoor, station type, pedestal mounted $120 \mathrm{kV}$ lightning arresters shall be designed, manufactured and tested in accordance with the latest applicable ANSI, IEEE and NEMA Standards for outdoor station type lightning arresters.

Each outdoor station type lightning arrester shall be rated as follows:

Nominal Circuit Voltagc

Arrester Voltage Rating

Max. ANSI Front of Wave Sparkover

Max. 1.2 × 50 Microsecond Sparkover

Max. Switching Surge Protective Characteristic
$138 \mathrm{kV}$ RMS

$120 \mathrm{kV}$

$338 \mathrm{kV}$ Crest

$282 \mathrm{kV}$ Crest

$272 \mathrm{kV}$ Crest 
Min. $60 \mathrm{~Hz}$ Sparkover

$168 \mathrm{kV}$ RMS

Max. Discharge Voltage with $1.5 \mathrm{kA}$. Impulse

$226 \mathrm{kV}$ Crest

Current of $8 \times 20$ Microseconds

Each arrester shall be pedestal mounted, furnished with a connector for 300 MCM ACSR, bare stranded conductor and furnished with a ground connector sized for a $250 \mathrm{MCM}$ bare stranded copper conductor.

\section{Section $8-138 \mathrm{kV}$ Outdoor, Transmission 0il Power Circuit Breaker}

The $138 \mathrm{kV}$ outdoor oll power circuit breaker shall be designed, tested and manufactured in accordance with applicable ANSI and NEMA standards, and with ANSI Standards C37.06 and C37.6. It shall be a 3 pole, 3 tank, floor mounted, electrically operated, stored energy type, 1600 ampere, transmission oil power circuit breaker; to be furnished with the following:

A welded structural steel base with the complete breaker, all three tanks, mounted thereon.

A complete operating mechanism control for all three phases with a common weather proof mechanism housing.

Six $145 \mathrm{kV}$ condenser type bushings, two per tank, with connectors arranged to receive No. $300 \mathrm{MCM}$ bare stranded ACSR conductor.

Nine $1600 / 5$ ampere multi-ratio bushing type current transformers with relaying accuracy and with their secondaries wired to the shorting terminal blocks in the breaker's operating mechanism's housing.

The $138 \mathrm{kV}$ outdoor oil power circuit breaker shall be rated and shall meet the following requirements:

Maximum rated voltage $145 \mathrm{kV}$.

Rated continuous current 1200 amperes.

Rated short circuit

Interrupting current

RMS-symmetrical

Short circuit MVA rating

Closing and latching amperes

3 second ampere rating

Interrupting time

Impulse withstand $\underline{145 \mathrm{kV}} \quad \underline{138 \mathrm{kV}}$

$\begin{array}{rr}\frac{145 \mathrm{kV}}{40 \mathrm{kA}} & \underline{138 \mathrm{kV}} \\ 10,000 \mathrm{MVA} & 8,590 \mathrm{MVA} \\ 64 \mathrm{kA} & 58 \mathrm{kA} \\ 40 \mathrm{kA} & 36 \mathrm{kA}\end{array}$

3 cycles

$650 \mathrm{kV}$ 
Section 9 - Outdoor, 0il Immersed, $138 / 6.9 / 6.9 \mathrm{kV} 3$ Phase 3 Winding Power Transformer

The $138 / 6.9 / 6.9 \mathrm{kV}$ outdoor, 3 phase 3 winding power transformer shall be designed, manufactured and tested in accordance with the latest applicable ANSI and NEMA standards. It shall be an outdoor, oil immersed, 3 phase, 3 winding, $60 \mathrm{~Hz}, 138 / 6.9 / 6.9 \mathrm{kV}$ power transformer rated as follows:

H - Winding - $138 \mathrm{kV}$ - Delta Connected 30/39.9 MVA OA/FA

X - Winding - 6.9 kV - Delta Connected - 15/20 MVA OA/FÁ

Y - Winding $6.9 \mathrm{kV}$ - Wye Connected - 15/20 MVA ON/FA

The rating of each winding based on a $55^{\circ} / 55^{\circ}$ temperature rise.

Basic impulse level - $650 \mathrm{kV}$

Approximate impedances $-\mathrm{Zxh}=10 \% ; \mathrm{Zxy}=20 \% ; \mathrm{Zyh}=10 \%-$ all on a 30 MVA "OA" base.

The transformer shall be furnished with or have the following features:

Three $138 \mathrm{kV}$, condenser type, outdoor, cover bushings; each with connectors to receive a $300 \mathrm{MCM}$, ACSR bare stranded conductor.

Three $7.5 \mathrm{kV}$, condenser type, cover bushings for the Delta connected 6.9 $\mathrm{kV}$ windings and arranged for connection to a 2000 ampere, $7.5 \mathrm{kV}$ outdoor non-segregated, metal enclosed bus.

Three $7.5 \mathrm{kV}$ condenser type, cover bushings for the wye connected $6.9 \mathrm{kV}$ windings and arranged for connection to a 2000 ampere, $7.5 \mathrm{kV}$ outdoor non-segregated, metal enclosed bus.

A base mounted, self-supporting, steel tank with the required removable cooling radiators.

The required fan motor control equipment will be furnished to completely control the cooling fans by the transformer's winding temperature.

Four $2-1 / 2 \%$ voltage taps in the transformer's $138 \mathrm{kV}$ winding with a manual, externally operated, de-energized tap changer.

Mechanical relief device, arranged to relieve abnormally high internal pressure and mounted in the cover of the transformer.

The $138 \mathrm{kV}$ transformer windings shall be furnished with a shielded disk winding construction (Faraday Shield). 
One $7.5 \mathrm{kV} 600$ ampere, neutral cover bushing for the wye connected 6.9 $\mathrm{kV}$ winding's neutral; with a $600 / 5$ ampere multi-ratio bushing type current transformer.

The transformer shall be furnished with the necessary instruments, gauges, relays, alarm and tripping contacts.

The transformer shall also be furnished with a complete oil preservation system; grounding pads; lifting lugs and eyes and provisions for jacking .

Section $10-7.5 \mathrm{kV}$ Outdoor, Metal Enclosed Switchgear Assembly

The $7.5 \mathrm{kV}$ outdoor, metal enclosed, weatherproof draw-out type switchgear assembly shall be designed, manufactured and tested in accordance with applicable ANS I and NEMA standards and with the American National Standard Test Procedure for AC High-Voltage Circuit Breakers, C37.09 and C37.09a. The switchgear assembly shall be furnished with the following:

An outdoor, welded, base mounted, self-supporting, weatherproof steel enclosure, arranged to be installed on a flat concrete pad and to house two (2) 2000 ampere air circuit breaker units and associated equipment as follows:

Each of the two (2) $7.5 \mathrm{kV}$ air circuit breaker compartments sha11 be furnished with:

One $7.5 \mathrm{kV}$, draw-out type 2000 anpere, electrically operated, stored energy type incoming air circuit breaker; complete with 7.5 $\mathrm{kV}$ primary bus disconnecting means; 125 volt D.C. closing, shunt tripping and controlling circuits; all of which are connected and disconnected when the breaker is inserted and withdrawn from the switchgear enclosure.

A 2000 ampere, $7.5 \mathrm{kV}$ incoming insulated copper bus section arranged for connection to the breaker's disconnecting means and to the incoming $7.5 \mathrm{kV} 2000$ ampere, 3 conductor non-segregated bus on the top side.

A 2000 anpere, $7.5 \mathrm{kV}$ outgoing insulated copper bus section arranged for connection to the breaker's disconnecting means and to the outgoing $7.5 \mathrm{kV} 2000$ ampere, 3 conductor, non-segregated bus.

Six (6) $2000 / 5$ ampere, multi-ratio current transformers, each with metering accuracy.

Three (3) draw-out type, fused $4.0 / .12 \mathrm{kV}$ potential transformers, connected wye and fused on both the primary and secondary sides, shall be furnished with the air circuit breaker compartment to be 
connected to the $6.9 \mathrm{kV}$ wye winding of the main transformer. These potential transformers shall be connected on the incoming side of the air circuit breaker. See Drawing No. EE-101.

Two (2) drawout type, fused $6.9 / .12 \mathrm{kV}$ potential transformers, connected open delta and fused on both the primary and secondary sides, shall be furnished with the air circuit breaker compartment, to be connected to the $6.9 \mathrm{kV}$ delta winding of the main transformer. These potential transformers shall be connected on the incoming side of the air circuit breaker. See Drawing No. EE-101.

A ground detecting unit shall be furnished with the air clrcuit breaker compartment to be connected to the $6.9 \mathrm{kV}$ delta winding of the transformer.

Each of the two $7.5 \mathrm{kV}$ air circuit breaker compartments shall be furnished with a hinged control panel within the weatherproof enclosure on which shall be mounted:

A circuit breaker control switch to be used to control the breaker when in the test position.

Three indicating lights.

Three very inverse time over current protective relays, each with an instantaneous trip attachment.

An inverse ground time over current protective relay, connected to the neutral current transformer of the main transformer $6.9 \mathrm{kV}$ wye winding. To be furnished only on the control panel of the circuit breaker connected to the $6.9 \mathrm{kV}$ wye winding of the main transformer.

The $7.5 \mathrm{kV}$ outdoor, metal enclosed, draw-out type switchgear assembly sha11 be ialed as fullüws:

\section{Circuit Breaker}

Rated Voltage

Rated Continuous Current

Rated 3 Phase Symmeterical MVA

Ratcd As ymmetrical Rating Factor

Momentary Withstand Current

Interrupting Rating - RMS

Symmetrical Amperes at $6.9 \mathrm{kV}$

Close and Latch Rating

Interrupting Time

Rated Maximum Voltage kV, RMS

Insulation Level

Low Frequency Withstand
$7.5 \mathrm{kV}$

2000 Amperes

500 MVA

1.25

$66 \mathrm{kA}$

$41.9 \mathrm{kA}$

$66 \mathrm{kA}$

5 Cycles

$8.25 \mathrm{kV}$

$30 \mathrm{kV}$ 


$\begin{array}{ll}\text { Temperature Rise } & \\ \text { Contacts and Joints } & 65^{\circ} \mathrm{C} \\ \text { Insulation "Class B" } & 80^{\circ} \mathrm{C} \\ \text { Terminals } & 45^{\circ} \mathrm{C} \\ \text { Operating Mechanism } & \text { Stored Energy } \\ \text { Operating Mechanism } & \text { Voltage } \\ \text { Closing Circuit } & 125 \text { Volts D.C. } \\ \text { Shunt Trip Circuit } & 125 \text { Volts D.C. } \\ \text { Control Circuit } & 125 \mathrm{Volts} \mathrm{D.C.} \\ \text { Insulation Impulse Level } & 95 \mathrm{kV}\end{array}$

$\underline{\text { Bus }}$

$\begin{array}{ll}\text { Rated Voltage } & 7.5 \mathrm{kV} \\ \text { Rated Continuous Current } & 2000 \text { Amperes } \\ \text { Momentary Withstand } & 66 \mathrm{kA} \\ \text { Insulation Level } & \\ \text { Low Frequency Withstand } & 30 \mathrm{kV} \\ \text { Impulse Withstand } & 95 \mathrm{kV} \\ \text { Temperature Rise } & \\ \quad \text { Joints } & 65^{\circ} \mathrm{C} \\ \text { Insulation "Class B" } & 80^{\circ} \mathrm{C} \\ \text { Terminals } & 45^{\circ} \mathrm{C}\end{array}$

Section $11-7.5 \mathrm{kV}$ Outdoor Metal Enclosed Bus

The $7.5 \mathrm{kV}$ outdoor totally metal enclosed, 3 phase, 3 wire, non-segregated, self-cooled bus shall be designed, manufactured and tested in accordance with the applicable ANSI standard for switchgear assemblies, including metal enclosed bus $\mathrm{C} 37.23$. It shall be used as follows:

Outdoor bus from main transformer's delta connected $6.9 \mathrm{kV}$ winding, consisting of two sections; see Drawings Nos. EE-101 and EE-102.

One section from the main transformer to $7.5 \mathrm{kV}$ outdoor switchgear unit.

One section from outdoor switchgear unit to the main motor controller.

Outdoor bus from main transformer's wye connected $6.9 \mathrm{kV}$ winding, consisting of two sections; see Drawings Nos. EE-101\& EE-102.

One section from the main transformer to $7.5 \mathrm{kV}$ outdoor switchgear unit, with a tap to the $7.5 \mathrm{kV}$ fused load break switch assembly; see drawing No. EE-101.

One section from the outdoor switchgear unit to the main motor controller. 
Bus Description and Rating of the Non-Segregated Outdoor Bus

Conductors

High conductivity copper extruded in square tube or channel.

\section{Enclosure}

A totally enclosed, self-supporting enclosure for an outdoor location in accordance with Drawing No. EE-102.

Insulators

Porcelain insulators, rated $15 \mathrm{kV}$ and bolted to the support member of the enclosure.

\section{Silver Plating}

The conductor surfaces shall be silvered for bolted connections.

\section{Grounding}

The bus enclosure shall be furnished with copper grounding connection pads at each end of the bus and all gasketed connections shall be shunted by a No. 2 AWG copper conductor.

\section{Bus Rating}

$\begin{array}{ll}\text { Design Voltage Rating } & 7500 \text { Volts } \\ \text { Nominal Voltage Rating } & 6900 \text { Volts } \\ \text { Nominal Current Rating } & 2000 \text { Amperes } \\ \text { Number of Conductors } & 3 \\ \text { Number of Phases } & 3 \\ \text { Basic Impulse Level } & 95 \mathrm{kV} \\ \text { Momentary Short Circuit. Withstand } & 40 \mathrm{kA} \\ \text { Temperature Rise } & 65^{\circ} \mathrm{C} \text { above } 40^{\circ} \mathrm{C} \text { ambient }\end{array}$

The non-segregated bus tap shall be rated as follows:

$\begin{array}{ll}\text { Design Voltage Rating } & 7500 \text { Volts } \\ \text { Nominal Voltage Rating } & 6900 \text { Volts } \\ \text { Nominal Current Rating } & 300 \text { Amperes } \\ \text { Number of Conductors } & 3 \\ \text { Number of Phases } & 3 \\ \text { Basic Impulse Level } & 95 \mathrm{kV} \\ \text { Momentary Short Circuit Withstand } & 60 \mathrm{kA} \\ \text { Temperature Rise } & 65^{\circ} \mathrm{C} \text { above } 40^{\circ} \mathrm{C} \text { ambient }\end{array}$




\section{Section $12-7.5 \mathrm{kV}$ Indoor Metal Enclosed Bus}

The $7.5 \mathrm{kV}$ indoor totally metal enclosed, 3 phase, 3 wire, non-segregated, self-cooled bus shall be designed, manufactured and tested in accordance with the applicable ANSI standard for switchgear assemblies, including metal enclosed bus $\mathrm{C} 37.23$. It shall be used as follows:

Indoor non-segregated bus from the main motor controller to the main synchronous drive motor of the helfum circulator.

Bus Description and Rating of the Non-Segregated indoor bus.

\section{Conductors}

High conductivity copper extruded in square tube or channel.

Enclosure

A totally enclosed, self-supporting enclosure from an indoor location in accordance with Drawing No. EE-102.

\section{Insulators}

Porcelain insulators, rated $15 \mathrm{kV}$ and bolted to the support members of the enclosure.

Silver Plating

The conductor surfaces shall be sllvered for bolted connections.

\section{Grounding}

The bus enclosure shall be furnished with copper grounding connection pads at each end of the bus and all gasketed connections shall be shunted by a No. 2 AWG bare copper conductor.

$\underline{\text { Rating }}$

$\begin{array}{ll}\text { Design Voltage Rating } & 7500 \text { Volts } \\ \text { Nominal Voltage Rating } & 6900 \text { Volts } \\ \text { Nominal Current Rating } & 4000 \text { Amperes } \\ \text { Number of Conductors } & 3 \\ \text { Number of Phases } & 3 \\ \text { Basic Impulse Level } & 95 \mathrm{kV} \\ \text { Momentary Short Circuit Withstand } & 40 \mathrm{kA} \\ \text { Temperature Rise } & 65^{\circ} \mathrm{C} \text { above } 40^{\circ} \mathrm{C} \text { ambient }\end{array}$


Section 13 - Neutral Grounding Transformer and Resistor for Hellum Circulators Main Drive Motor

The Helium circulator's main drive motor shall be grounded through a transformer, connected between the motor's neutral point and the ground and loaded by a secondary resistor:

The neutral grounding transformer shall be rated as follows:

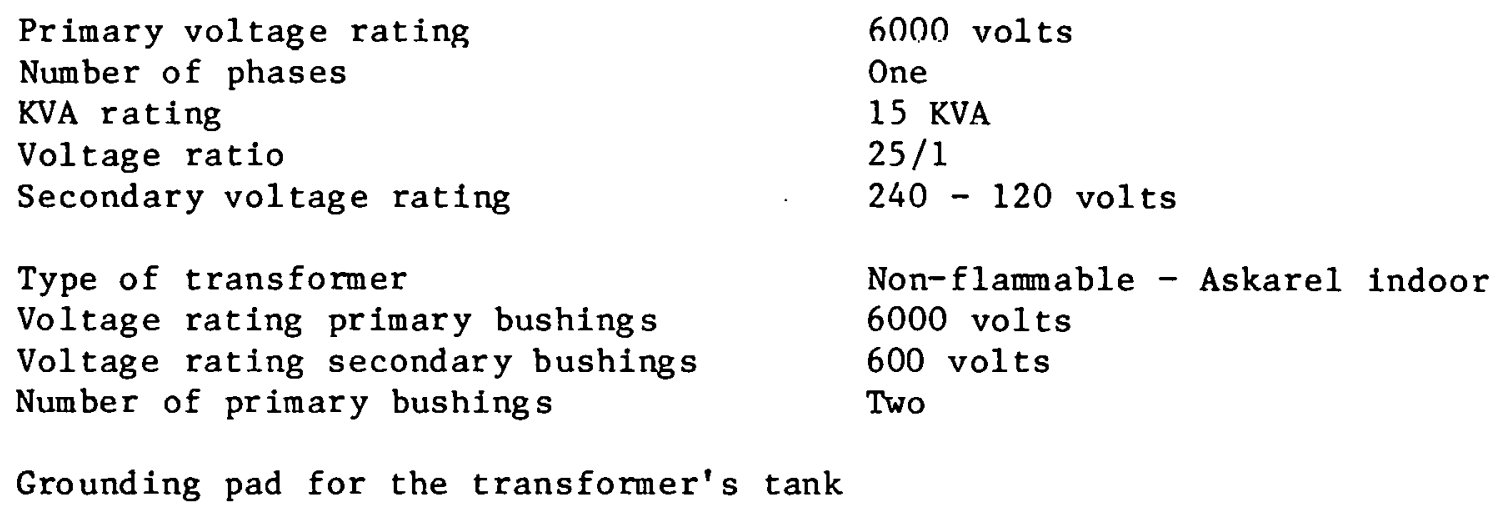

Grounding pad for the transformer's tank

The secondary resistor shall be rated as follows:

Voltage rating

F.L. ampere rating

Resistance rating

Enclosure

Material of resistor's plates
240 volts A.C. 60 amperes 1.95 ohms Indoor protective screen Stainless steel

Connectors sized to receive No. 1/0 - AWG 600 volt power cable

Grounding pad for the enclosure

The neutral grounding transformer and the resistor will be installed indoors in the Test Building.

\section{Section 14 - Outdoor, Pedestal Mounted $6.9 \mathrm{kV}$ Transformer Neutral Grounding Reactor}

The outdoor, pedestal mounted $6.9 \mathrm{kV}$ transformer neutral grounding reactor shall be designed, manufactured and tested in accordance with the latest applicable ANSI and NEMA standards.

The reactor shall be rated as follows:

$\begin{array}{ll}\text { Insulation Class } & 7.5 \mathrm{kV} \\ \text { Number of Phases } & 1 \\ \text { Terminals } & \text { Silver plated } 90^{\circ} \text { apart } \\ \text { Continuous Ampere Rating } & 600 \text { Amperes } \\ \text { Short Time Ampere Rating } & 4.6 \mathrm{kA} \text { for } 4.0 \text { seconds } \\ \text { Momentary Withstand Rating } & 10 \mathrm{kA}\end{array}$


Basic Impulse Leve1

Reactance - OHMS

Supporting Insulator - Post Type

Type of Mounting

Type of Construction

Number of Reactors Required
$60 \mathrm{kV}$

0.71 OHMS on $6.9 \mathrm{kV}$ base

$7.5 \mathrm{kV}$

Pedestal

Outdoor

1

Section $15-7.5 \mathrm{kV}$ Outdoor, Metal Enclosed Switchgear with Load Interrupting Fused Switches.

The $7.5 \mathrm{kV}$ outdoor, metal enclosed fused interrupter switch assembly shall be designed, manufactured and tested in accordance with the applicable ANSI and NEMA Standards. The assembly shall consist of the following:

An outdoor, weather-proof, pad mounted supporting enclosure with a 7.5 $\mathrm{kV}$ bus entrance compartment, with the bus arranged to connect to the Incoming 300 ampere non-segregated bus duct on the top side and three individual compartments, each with a hinged locked door.

- One incoming compartment with a $7.5 \mathrm{kV} 600$ ampere bus section, a manually group operated, 3 pole, 600 ampere fused, load break disconnect switch and three $7.5 \mathrm{kV}$ wound type current transformers, wired to outgoing terminals, for use in the main transformer's differential relaying system. (See Drawing EE-101).

- Two outgoing compartments, each with a $7.5 \mathrm{kV} 600$ ampere bus section, a manually group operated, 3 pole, 600 ampere fused, load break disconnect switch and space to terminate three single conductor $4 / 0$ awg, $7.5 \mathrm{kV}$ shielded power cables entering from the bot tom side.

Each fuse interrupter switch assembly shall be rated as follows:

$\underline{\text { Each Switch }}$

Continuous Ampere Capacity

Interrupting Capacity

Number of Poles

Momentary Withstand

Operating Mechanism
600 Amperes

600 Amperes

3

$80 \mathrm{kA}$

Manually Group Operated

Fuse

Rating

Interrupting Rating $6.9 \mathrm{kV}$

Momentary Withstand

Number of Fuses
$200 \mathrm{E}$

$600,000 \mathrm{kVA}$

$80 \mathrm{kA}$

3

Bus 
Bus (Contd)

$\begin{array}{ll}\text { Maximum Design Voltage Rating } & 7.5 \mathrm{kV} \\ \text { Basic Impulse Level } & 95 \mathrm{kV} \\ \text { Momentary Withstand } & 80 \mathrm{kA}\end{array}$

The arrangement of the fused interrupter switch assembly shall be in accordance with Drawings Nos. EE-101 and EE-102.

Section $16-6.9 / .48 \mathrm{kV}$ Outdoor Load Center Transformers

The $6.9 / .48 \mathrm{kV}$ outdoor, oil immersed, 3 phase load center power transformers shall each be designed, manufactured and tested in accordance with the latest applicable ANSI and NEMA standards. Each load center transformer shall be an outdoor, oil immersed, 3 phase, 2 winding, $60 \mathrm{~Hz} 6.9 / .48 \mathrm{kV}$ power transformer rated as follows:

$\begin{array}{ll}\text { Transformer capacity } & 1000 / 1150 \mathrm{KVA} \text { "OA/FA" } \\ \text { Temperature rise } & 55^{\circ} / 55^{\circ} \\ \text { High voltage winding connection } & \text { Delta } \\ \text { Low voltage winding connection } & \text { Wye } \\ \text { High voltage winding BIL } & 95 \mathrm{kV} \\ \text { Impedance } & 5.0 \% \text { on } 1000 \mathrm{KVA} \text { base }\end{array}$

Each $6.9 / .48 \mathrm{kV}$ transformer shall be furnished with the following:

Painted steel, all welded transformer tank, welded to a welded structural steel base, formed using structural steel I beams.

Three $7.5 \mathrm{kV}$ bushings to be furnished housed in an a1r-insulated steel terminal chamber, arranged for one 4 inch incoming steel conduit, with three single conductor 非/0 AWG, $7.5 \mathrm{kV}$ power cables, entering the bottom side of the terminal chamber. Each bushing shall be rated 600 amperes.

The required cooling units shall have 480 volt A.C. single phase motor driven cooling fans, if $1 / 4$ hp or less. Larger motors shall be three phase.

The required fan motor control equipment, shall completely control the cooling fans operation as a function of the transformer's winding temperature.

Three, 1600 ampere 600 volt bushings shall be furnished, housed in an air-insulated steel terminal chamber arranged to be connected to a 1600 ampere, 3 phase, metal enclosed bus duct. This bus duct shall be installed overhead and enter the top side of the terminal chamber. 
Four $2-1 / 2 \%$ voltage taps in the transformer's $6.9 \mathrm{kV}$ winding with a manual, externally operated de-energized tap changer.

Mechanical relief device, arranged to relieve abnormally high internal pressure and mounted in the cover of the transformer.

A 600 volt neutral bushing for the wye connected $0.48 \mathrm{kV}$ windings neutral connection. The bushing shall be mounted in an accessible steel enclosure, attached to the transformer's tank and housing in addition the neutral bushing the following:

One neutral grounding indoor reactor rated 0.4 ohms on a 480 volt base and $5 \mathrm{kA}$ for 5 seconds. This reactor shall be self-cooled, self-supporting and arranged to be connected to the grounding grid.

The transformer shall also be furnished with the following instruments gauges and relays:

Magnetic liquid level gauge with alarm contacts. Dial type thermometer with red peak temperature pointer and alarm contacts to measure the temperature of top liquid.

A complete oil preservation system with all required valves, pressure and vacuum gauges.

One transformer tank grounding pad on the back and one on the front side of the transformer tank.

Provisions for jacking.

Lifting lugs and eyes.

Instruction nameplate - stainless steel - mounted on transformer tank.

Section 17 - 600 Volt Outdoor Metal Enclosed Bus

The 600 volt outdoor, totally metal enclosed, 3 phase, 3 wire nonsegregated, self-cooled bus shall be designed, manufactured and tested $1 \mathrm{n}$ accordance with the applicable ANSI standard for switchgear assemblies, including metal enclosed bus $\mathrm{C} 37.23$. It shall be used to connect each $6.9 / .48 \mathrm{kV}$ load center power transformer to its associated 480 volt double ended switchgear, located in the electric equipment room. See Drawings Nos. EE-101 and EE-102.

Description of The Non-Segregated Bus

Conductor

High conductivity copper extruded in square tube channel.

Enclosure

Total enclosed, self-supporting, weatherproof enclosure for an outdoor location. See Drawing No. EE-102. 
Insulators

Porcelain insulators, rated 600 volts and bolted to the support member of the enclosure.

Silver Plating

The conductor surfaces shall be silvered for bolted connections.

Grounding

The bus enclosure shall be furnished with copper grounding connection pads at each end of the bus. All gasketed connections shall be shunted by a No. 2 AWG copper conductor.

Conductor Insulation

The conductors sha11 be bare copper.

Finish

All enclosing surfaces shall be shot blasted to assure a uniform, clean painting surface, followed by a zinc chromate primer and then two coats of an air dry lacquer.

The bus shall be rated as follows:

$\begin{array}{ll}\text { Nominal Voltage Rating } & 600 \text { Volts } \\ \text { Nominal Current Rating } & 1600 \text { Amperes } \\ \text { Number of Conductors } & 3 \\ \text { Number of Phases } & 3 \\ \text { Momentary Short Circuit Withstand } & 30 \mathrm{kA} \\ \text { Temperature Rise } & 65^{\circ} \mathrm{C} \text { above } 40^{\circ} \mathrm{C} \text { Ambient } \\ \text { Number of Bus Runs } & 2\end{array}$

The number of elbows, terminating boxes and length of the bus sections shall be in accordance with Drawing No. EE-102.

The 600 volt bus shall be installed outdoors.

Section 18 - 480 Volt Switchgear (Double Ended Load Center)

The 480 volt switchgear assembly shall be drawout circuit breaker equipment conforming to NEMA Standards SG-3 \& SG-5, and ANSI C-36.01 and C37.20.

The switchgear shall be rated 480 volts, three phase, three wire, $60 \mathrm{~Hz}, 2000$ amperes. Bussing shall be copper and shall be braced to the short circuit rating of the largest breaker. The arrangement shall be double ended as shown on Drawings Nos. EE-101 and E102..

Power circuit breakers shall be stored energy type, electrically operated, air circuit breakers, complete with static trip unit with long-time, shorttime, instantaneous and integral ground fault protection. The 480 volt feeder breakers shall. be. furnished without an instantaneous trip unit. The breakers 
shall have the following ratings at 480 volts:

\begin{tabular}{rr} 
Continuous Rating - Amps & Short Circuit Rating \\
\cline { 2 - 2 } 800 & 30,000 \\
1,600 & 30,000
\end{tabular}

The bus tie breaker shall have automatic throw-over control. The main and tie breakers of the switchgear assembly shall be electrically interlocked to permit no more than two of the three breakers to be closed at one time. All controls shall be local. The incoming section shall accommodate 1600 ampere non-segregated copper bus duct.

A watthour meter, indicating ammeter, indicating voltmeter and undervoltage relay with associated current transformers, potential transformers and selector switches shall be provided for each 480 volt bus section.

A full length copper ground bus shall be provided.

The number and the ampere rating of each incoming, outgoing and bus tie breaker for the 480 volt switchgear assembly shall be in accordance with Drawing No. EE-101.

\section{Section $19-480$ Volt Motor Control Centers}

Motor control centers shall be NEMA Class II, Type B wiring. The enclosure shall be NEMA Type I. The rating shall be 480 volts, three phase, three wire, 60 Hertz with 600 ampere main copper bus, braced for 22,000 amperes symmetrical minimum, short circuit duty.

Vertical sections shall be free standing self-supporting, dead front, dead rear structures approximately 20 inches wide, 11 inches deep, and 90 inches high, conforming to NEMA Standard ICS-1. Each vertical section shall be complete with full length vertical and horizontal copper buses and wiring troughs which match and line up with adjacent sections. Each section shall contain not more than five (5) size 1 or 2 starters or equivalent.

Unit compartments for motor and other feeder circuits through size 4 starters and 400 ampere circuit breakers shall be of the plug-in type readily removed from the front.

Each motor starter cubicle shall consist of a combination magnetic contactor with overloads, a molded case, magnetic trip only circuit breaker, a 480/120 volt control power transformer, a red indicating light and start-stop pushbuttons .

Each control power transformer shall be sized for the next larger NEMA sized starter.

Each motor starter shall also be wired for a remotely located control section. 
Each manually operated circuit breaker's short circuit rating at 480 volts shall be at least 22,000 amperes symetrical.

The number, arrangement, ampere rating and starter size shall be in accordance with Drawings Nos. EE-101 and EE-102.

Section 20 - Battery Panels and 125 Volt D.C. System

The battery panel shall consist of one 2 pole molded case air circuit breaker with a thermal magnetic trip mounted in a common NEMA 1 steel enclosure.

The circuit breaker shall be operable by external lockable handle with open and closed position identified on the door. The circuit breaker shall conform to Federal Specification W-C-375. All components shall be UL 1 isted.

\section{Volt Station Battery}

The storage battery shall consist of sixty (60) cells with a nominal rating of 320 ampere-hours and a nominal output of 125 volts, mounted in a three tier rack. The battery cells shall be the sealed lead-acid calcium assembled in a heat resistant shock absorbing clear plastic container. The cell design shall provide for adequate sediment for the normal life of the cell, and electrolyte level lines shall be clearly marked on the container.

Intercell connectors shall be lead-plated copper.

The battery shall be furnished with a three tier, Uniform Building Code Zone 3 type steel rack finished with two coats of epoxy base acid-resistant paint.

\section{Battery Charger}

The battery charger shall be of the solid state constant potential type with a regulated uutpuc voltage stability of $1 \%$ from zero to full nominal current rating over an input voltage variation of $10 \%$. The input shall be 480 volts, 60 Hertz, 3 phase A.C. The output shall be 200 amperes, 130 volts D.C. nominal. Separate FLOAT and EQUALI7.E volt adjustments shall be provided. Features shall include the following:

1 - FLOAT/EQUALIZE selector switch

1 - Output ameter and voltmeter, $2 \%$

$1-$ - AC ON" lamp

$1-\Lambda C$ power loss alarm relay

1 - Low DC voltage alarm relay

1 - High DC voltage alarm relay 
1 - Low DC current alarm relay

1 - Ground detection switch using output voltmeter

1 - "EQUalize ON" lamp

\section{Section 21 Public Address System}

The following public address system shall be added to the existing public address system as required to provide the test facility with an adequate system.

\section{Power Amplifier}

Type

Output

Frequency response

Load voltage

Control

Input power source

Auxiliary output

Mounting type

Enclosure

Input
(Four Required)

Solid State, temperature stabilized

200 watts rms

20 to $20,000 \mathrm{~Hz}+1 \mathrm{db}$

25 and 70 volts

input level control

105-125 volts, $60 \mathrm{~Hz}$

28 volts D.C. at $50 \mathrm{ma}$

maximum

19-1nch wide rack mounting

Ventilated wall hung

Provide input transformer to match preamplifier

(Four Required)

\section{Preamplifier}

Remote preamplifier, designed for outlet box mounting near microphone station, to include microphone receptacle and volume control mounted in face.

Gain

Input impedance

Load impedance

Output level

Frequency response

Input power source

Microphone
$60 \mathrm{db}$

$150 / 200$ ohms

$600 \mathrm{ohms}$

$+8 \mathrm{dbm}$

$100-15,000 \mathrm{~Hz}+2 \mathrm{db}$

$5 \mathrm{~mA} @ 24 \mathrm{VDC}$

(One Required)

Furnish with 15 feet of cable and desk stand.

Type

Pattern

Frequency range

Output level

Impedance
Crystal

Cardiod

40 to $15,000 \mathrm{~Hz}$

$-55 \mathrm{db}$

Low (150 ohms) 


\section{Speakers \& Horns}

$\begin{array}{ll}\text { Horns 'required indoor } & 4 \\ \text { Horns required outdoor } & 6 \\ \text { Speakers required indoor } & 5\end{array}$

Indoor horns shall be directional with built-in tapped, matching transformer for 70 volt line as follows:

Power rating

Frequency response

Sound pressure level

Distribution

Mounting

Transformer taps

Outdoor horns shall be similar to indoor horns, except they shall be weatherproof and have approximately $120^{\circ} \times 60^{\circ}$ distribution.

Speakers for use in offices and corridor areas shall be permanent magnet type mounted in a sloped front, wall mounting, vinyl finish baffle, complete with 70 volt matching transformer. Speaker rating shall be as follows :

Power rating

Size and type

Frequency response

Transformer taps
30 watts full range

$250-13,000 \mathrm{~Hz}$

$123 \mathrm{db}$ at 4 feet on axis

with 30 watts

$100^{\circ}$

Three-way adjustable

$1.8,3.7,7.5,15,30$ watts

Section $22-7.5 \mathrm{kV}$ and 600 Volt Power Cables

The $7.5 \mathrm{kV}$ power cables shall be designed, manufactured and tested in accordance with the latest applicable IPCEA standards for "EPA" or "XLP" insulated, shielded, single or three conductor power cables, with a "PVC" or neoprene outer jacket.

The $7.5 \mathrm{kV}$ power cables shall be rated as follows:

Conductor material

Insulation material

Outer jacket material

Nominal circuit voltage

Shielding material

Conductor temperature

Insulation level system
15 watts

8-inch PM type

250-13,000 Hz

$1 / 2,1,2,4$ watts

\section{.}


The 600 volt power cables shall be rated as follows:

Conductor material

Insulation material

Nominal circuit voltage

Conductor temperature

Insulation level
Stranded copper

"EPR" or "XLP"

480 volts

$98^{\circ} \mathrm{C}$

$100 \%$

Each power cable circuit, including $7.5 \mathrm{kV}$ and 600 volt power circuit, shall be installed in its individual conduit, which shall be complete with its individual pull boxes and terminating cabinets.

The above power cables shall be installed underground in PVC and galv. steel conduits. They shall also be installed above ground, both outdoors and indoors, in exposed galv. steel conduits.

The $7.5 \mathrm{kV}$ cables shall be installed in a $6.9 \mathrm{kV}$ power system with a grounded neutral and in a $6.9 \mathrm{kV}$ delta connected ungrounded power system. The 600 volt power cables shall be installed in power systems with their neutrals grounded.

\section{Section 23 - Control and Instrumentation Cables}

The control and instrumentation cables shall be designed, manufactured and tested in accordance with the latest applicable IPECA standards for nonflammable insulated, shielded and nonshielded, single and multi-conductor control and instrumentation cables.

The control and instrumentation cables shall be rated as follows:

\section{Control Cables - Single \& Multi-Conductor}

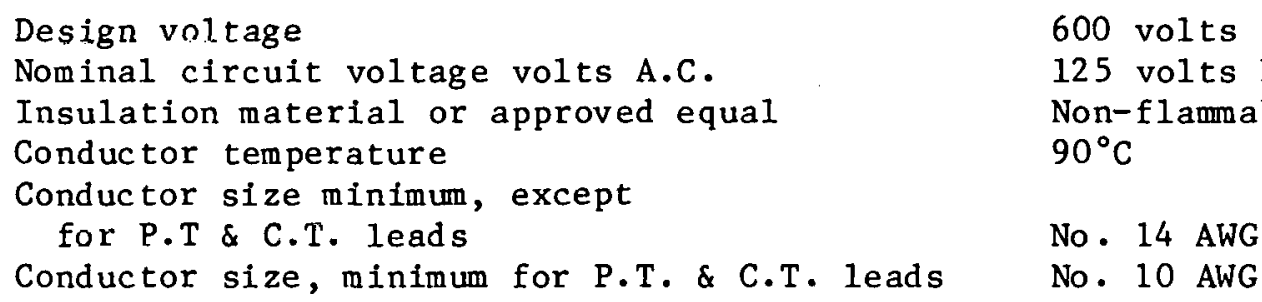

Instrument cabling shall be classified in accordance with current capacity and insulation.

A11 instrument cabling shall contain an overall shield, grounded at one point.

The control and instrumentation cables shall meet the requirements for "TC" cable tray cables and shall be approved for installation in ladder type galvanized steel cable trays. These cables shall be installed underground in "PVC" and galv. steel conduits. They shall be installed above ground, both outdoors and indoors, in exposed galvanized steel conduits; also indoors in galv. steel ladder type cable trays. 


\section{Section $24-$ Grounding System}

A11 electric equipment within the switchyard, transformer station and electric equipment room shall be connected to the existing grounding grid, using copper tee bolts at the equipment, a No. 4/0 stranded bare copper cable and a cadwelded connection at the grounding grid.

A11 electric motors, all steel support structures in the switchyard and transformer station area, all steel building columns, transformer neutral grounding reactors and resistors and all switchgear ground bus shall be connected to the grounding grid as outlined above.

All copper ground cables shall be insulated and installed in sealed PVC conduit, when located underground within 25 feet of any uninsulated steel (iron) tanks, vessels, piping or structural steel not encased in concrete. Any underground bonding of copper to steel must be fully insulated.

Section 25 - Protective Relays, Indicating and Recording Instruments, Indicating Lights, Control and Instrument Switches

The protective relays, indicating and recording instruments, indicating lights, and control and instrument switches shall be furnished installed on the steel relay and control panels to be installed in the main control room.

Protective Relays

Protective relays shall be furnished with semi-flush, drawout or flexitest cases, with current transformer shorting and potential transformer opening devices arranged for mounting on the control panels in the main control room. The types of relays and their features or purpose shall be:

Transformer differential relays - each with a tap plug for slope percentages of 15,25 or 40 and a harmonic-current restraint, for main transformer's differential relaying system.

Inverse time overcurrent relays - to provide backup protection for the main transformer's differential relaying system.

Hand reset lockout auxiliary tripping relay.

Ground alarm relay - to alarm a phase-to-ground condition in the circulator's main drive synchronous motor.

Over and under voltage alarm relays connected to $6.9 \mathrm{kV}$ bus potential transformers.

Over and under voltage alarm relays connected to, the $.48 \mathrm{kV}$ bus potential transformers.

Other required protective relays and protective fuses have been included with the $7.5 \mathrm{kV}$ and 480 volt switchgear units. 
Indicating and Recording Instruments, Indicating Lights, Control and Instrument Switches

Switchboard type ammeters, indicating:

1 phase of the 480 volt feeder from the $6.9 / .48 \mathrm{kV}$ load center transformers, with an ammeter selector switch.

Each phase of the incoming $138 \mathrm{kV}$ power.

Each phase of the $6.9 \mathrm{kV}$ feeders to the circulator's main drive motor both from the delta winding and wye winding of the main transformer.

1 phase of the 480 volt feeder to the 480 volt pony motor, with an ammeter selection switch.

Single phase switchboard type voltmeters, indicating:

Each phase of the incoming $138 \mathrm{kV}$ power.

Each phase of the $6.9 \mathrm{kV}$ power to the circulator's main drive motor

The secondary voltage of the neutral grounding transformer for the circulator's main drive motor, with two ranges; and switch.

The voltage of each $.48 \mathrm{kV}$ bus, supplying power to the auxiliaries, with a voltmeter switch.

1- Single phase switchboard type recording voltmeter, indicating one phase of the incoming $138 \mathrm{kV}$ power, with a voltmeter phase selection switch.

The Following Additional Instruments for the Circulator's Main Motor

2- Three Phase switchboard type watthour meter, one from the main transformer's delta winding and one from its wye winding.

2- Three phase, switchboard type power factor meter.

2- Single phase, switchboard type wattmeter.

1- Single phase, switchboard type recording voltmeter, two speed.

1- Single phase, switchboard type recording ammeter, two speed.

1- Three phase, switchboard type totalizing watthour meter.

1- Two range, flush mounted, switchboard type voltmeter switch.

2- One phase, flush mounted, switchboard type ammeter switch. 


\section{Additional Switchboard Control Devices}

Flush mounted switchboard type circuit breaker control switches; each with two switchboard type indicating lights (one green, one red). Each indicating light assembly shall be furnished complete with a resistor and a lamp assembly for operation in series across a 125 volt D.C. circuit.

Flush mounted, switchboard type, motor starter pushbutton stations, each with two indicating lights (one green and one red); each ind icating light assembly shall be furnished with a resistor and a lamp assembly for operation in series across a 120 volt A. C. circuit.

\section{Section 26 - Raceway Systems and Enclosures}

Conduits installed underground shall be encased in concrete. Underground conduits shall be Schedule 40 PVC 2 inch minimum size, except for short runs to equipment, which shall be PVC Schedule 40, 1 inch minimum. At equipment terminations, Schedule 40 PVC or rigid steel conduits will be used. For all underground conduit runs, elbows shall be Schedule 40 PVC.

Cable in the test facility building for control and instrumentation will be run in cable trays with connections from the tray to equipment and devices made with exposed or concealed rigid steel conduits or if underground, in Schedule 80 PVC conduits. Only control and instrument instrumentation cables shall be installed in cable trays.

Cable trays shall be ladder-type with 9 inch rung spacing, fabricated from galvanized steel or aluminum.

Al1 conduit runs exposed shall be galvanized rigid steel, $3 / 4$ inch minimum, except that for lighting raceways installed indoors, electric metallic tubing shall be used. All conduits embedded in structural concrete shall be galvanized rigld steel, or Schedule 80 PVC.

Enclosures for equipment and devices installed indoors shall be NEMA 1 gasketed. Enclosures for outdoor installations shall be NEMA 3 .

\section{Section 27 - Indoor and Outdoor Lighting}

The lighting circults shall be furnished power from the lighting trans formers and the lighting panels with the $208-120$ volt A.C. and 125 volt D.C. sections as specified in the dry type transformer and the panelboards outline specifications.

The interior lighting system shall provide lighting within all areas of the building and its entrances; using lighting fixtures with fluorescent, incandescent and mercury lamps where feasible, as follows:

\begin{tabular}{|c|c|c|}
\hline Area & Illumination & Type of Fixture \\
\hline Contol Room & $10 \overline{\mathrm{ft} \cdot \text { candles }}$ & F1 uorescent \\
\hline Shop & $100 \mathrm{ft}$. candles & Fluorescent \\
\hline
\end{tabular}




Office Area
Receiving and Prep. Room
Test Pit (at grade)
Equipment Roor
Toilet
Exterior Equipment Area
Exterior over doorways
High Bay Areas

$100 \mathrm{ft} \cdot$ candles
$60 \mathrm{ft} \cdot$ candles
$60 \mathrm{ft} \cdot$ candles
$20 \mathrm{ft}$. candles
$20 \mathrm{ft}$ candles
$2-5 \mathrm{ft} \cdot$ candles
$60 \mathrm{ft}$. candles

\author{
Type of Fixture \\ Fluorescent \\ Mercury Vapor or Lucalox \\ Mercury Vapor or Lucalox \\ Fluorescent \\ Fluorescent \\ Mercury Vapor or Lucalox \\ Mercury Vapor or Lucalox \\ Mercury Vapor or Lucalox
}

The emergency lighting shall be incandescent so that it may be supplied by either the station battery or an A.C. 1ighting transformer.

Lighting fixture mounting height and spacing shall not exceed the manufacturer's recomendations, except where physical requirements force some deviation.

The outdoor lighting system shall provide lighting in the cooling water air coolers area, in the pumping stations, in the switchyard and on all roadways. The general methods for lighting these areas shall be as follows.

\section{Cooling Water Air Coolers and Pumping Station}

Outdoor mercury or Lucalox floodlighting, adjustable flxtures supported by aluminum, tapered, pedestal type poles with single and double arms. Outdoor, incandescent, vapor-tight floodlighting fixtures supported by aluminum, tapered pedestal type poles. These fixtures shall be connected to the emergency lighting circuits.

\section{Switchyard}

Outdoor, Mercury substation type luminairs, supported by aluminum tapered pedestal type poles; with mercury type floodlighting units mounted lower on the supporting poles than the substation type luminairs. The substation luminairs are for lighting the tops of the electric power equipment, while the mercury flood lighting units are for general lighting requirements at the grade level.

Roadways and Parking Areas

Outdoor Lucalox roadway lighting fixtures, controlled by photo-electric controllers and supported by aluminum, straight poles with single and double arms.

The outdoor lighting fixtures mounting heights, spacings and areas cover shall not cxceed the manufacturer's recommendations and the light intensities shall be at least equal to the minimum recommended by the Illuminating Engineering Society.

\section{Section 28 - Dry Type Transformers}

Lighting transformers shall be two winding 60 Hertz, three phase, gencral purpose, dry type in ventilated enclosures for indoor use; with class 
H-80 or better insulation. Transformers shall conform to ANSI C89.1, NEMA STI-4, and UL-506, and shall be rated as shown on Drawing No. EE-101. Each rated at $45 \mathrm{KVA}$.

Instrumentation transformers shall be as above except the transformers shall have an electrostatic shield between the primary and secondary winding. The transformers shall be rated $25 \mathrm{KVA}, 480-120 / 240$ volts, single phase, three wire, 60 Hertz.

The required number of the various dry type transformers is as follows:

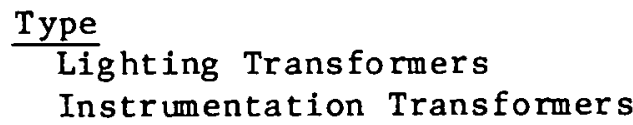

$\frac{\text { Required Number }}{2}$

\section{Section 29 - Panelboards}

All panelboards shall be UL listed, dead-front copper bus type, and shall conform to Federal Specification W-P-155a, Type I, Class 1. Circuit breakers shall be bolt-on type, 10,000 amperes interrupting rating minimum, and shall conform to Federal Specification W-C-375. Neutral buses where specified, shall be insulated from the enclosure. An equipment ground bus shall be provided in all panelboards.

Lighting panelboards shall be combination panels with lockable door consisting of three sections as follows:

$120 / 208$ volt, 3 phase, 3 wire, 225 ampere copper bus, solid neutral with 16 single pole 15 ampere circuit breakers; Each shall be furnished with an A.C./D.C. section for emergency lighting.

Instrumentation panelboards shall be 120 volt, single phase, three wire with neutral bar. Each panelboard shall be equipped with 12-15 ampere single pole circuit breakers and one 150 ampere main breaker. The main buses shall be rated 225 amperes. The 15 ampere air circuit breakers shall have ambient compensated thermal magnetic trip units only.

125 volt DC Main Distributing panelboard shall be circuit breaker type with 600 ampere main bus. Main and branch circuit requirements shall be shown on Drawing No. EE-101.

125 volt DC distribution panelboard shall be circuit breaker type with 400 ampere mains and the following branches:

$$
\begin{aligned}
& 10-30 \mathrm{~A}, 2 \mathrm{P} \\
& 6-60 \mathrm{~A}, 2 \mathrm{P}
\end{aligned}
$$

240 volt A.C. outdoor, distribution panel with a copper bus and four (4) outgoing 20 ampere air circuit breakers, each with an ambient compensated thermal magnetic trip unit only. The panel shall be furnished with an outdoor, weatherproof enclosure. 
The required number of the various panelboards is as follows:

Type -

Main D.C. Distr. Panelboards

Lighting Panelboards

Required Number

Instrumentation Panelboards

D. C. Distr. Panelboards

Outdoor Feeder Panel

\begin{tabular}{c} 
Required Number \\
\hline 1 \\
2 \\
2 \\
1 \\
1
\end{tabular}

\section{Section 30 - Instrumentation and Control}

\section{Control Valves}

The facility control valves shall be sized and selected to meet the project performance requirements, expected operating conditions and facility service requirements. Steel flanged valves shall be in accordance with ANSI B16.5-1977. Packing materials shall be suitable for the type of service. Valve actuators shall be diaphragm or piston type with positioner when required. Signal range shall be $3-15$ psig.

The helium loop restrictor valve shall be a 48 inch diameter type 7700 class 5 butterfly valve with a 43 inch fishtail disc rated at $1500 \mathrm{lb}$. ANSI. The actuator shall be a 12 inch cylinder with 24 inch stroke. The valve shall be furnished with a 3-15 psig positioner and a handwheel.

The helium loop depressurization valve shall be a 8 inch diameter type EH globe valve with a 7 inch nominal port and Whisper Trim III cage rated at $15001 \mathrm{~b}$. ANSI. The valve shall be furnished with a pneumatic actuator, a 3-15 psig positioner and a handwheel.

\section{Depressurization System}

The helium loop depressurization system shall be designed to simulate a design basis depressurization accident for the demonstration plant. The system shall consist of a pneumatic actuated control valve provided with a positioner and characterizing cam and the necessary electronic and pneumatic hardware to program the valve to open in approximately 80 seconds. The electronic and pneumatic hardware shall be manufacturer's standard and shall be housed in a control cabinet which shall be mounted locally. The depressurization system shall be designed for both local initiation and for intiation from the main control room.

\section{Control Equipment Cabinets}

All signal conditioning equipment, power supplies and other necessary control equipment shall be mounted in the facility control equipment cabinets and shall be wired out to terminal blocks located in a separate area of the control equipment cabinets. The control equipment cabinets shall be located adjacent to the main control room and shall be interconnected with the main control panels by prefabricated cables. The control equipment cabinets shall be 90 inch high free-slaudlug, tocally enclosed, dust-tight, NEMA 12 construction and shall be fabricated from a minimum of 12-gauge steel. The 
panel interior and exterior shall be painted with a primer and at least one finish coat of paint.

\section{Control Panels and Panel Mounted Instruments}

Facility control shall be accomplished from the main control room and from local control stations. Electronic controls with a 4-20 ma signal range shall be furnished. Valve actuators and some local controls shall be pneumatic with a 3-15 psig signal range. The facility panel mounted instruments including annunciator, indicators, controllers, recorders, switches, 1 ights, and pushbuttons shall be manufacturer's standard and shall be furnished with the vertical control panels. The control panels shall be located in the existing control room.

The 84 inch high control panels shall be fabricated in conventional self-supporting steel framed sections. Control panels shall be Nema 1 construction furnished complete with top, side and rear surfaces and shall have rear access doors. The panels shall be fabricated from $3 / 16$ inch steel plate, leveled and stiffened as necessary to support the instruments and other devices. Panel interior and exterior shall be painted with a primer and at least one finish coat of paint.

\section{Field Mounted Instruments}

Facility instrumentation including gages, indicators, transmitters, control valves, transducers, controllers, switches and analyzers shall be manufacturer's standard and shall be mounted locally on the process piping and equipment or nearby. Control signals and alarms are transmitted back to the control equipment cabinets in the cable spreading room or to local control stations.

The helium loop flow measurement shall be accomplished with a flanged annubar element, model ANF, sensor type 86 installed two pipe diameters from a 90 degree elbow in the 50 inch diameter piping. Accuracy shall be $\pm 3 \%$ or better. Repeatability shall be $\pm 0.1 \%$ or better. 
SECTION 10

COST ESTIMATE FOR NEW GCFR HELIUM CIRCULATOR TEST FACILITY

\subsection{INTRODUCTION}

All of the preceding information in this document addresses the incorporation of the GCFR Helium Circulator test equipment and support systems intc the HTGR Helium Circulator Test Facility. This section addresses an approximation to the cost for the construction of a new GCFR Helium Circulator Test Facility with the same mission, test equipment and requirements.

\subsection{BASIS OF DESIGN AND ESTIMATE}

Neither time nor budget permitted the execution of a conceptual design for a new building and facllity to house and support the horizontal c1rculator and drive motor concept. However, it was noted that the equipment necessary to accommodate the concept nicely filled the HTGR-HCTF building, as shown on the drawings in section 8 of this document. Therefore, it was assumed that a building of the HTGR-HCTF square footage would be required for a new facility. The conceptual design for the previous GCFR-HCTF, as described in document GA-A15300, "Gas Cooled Fast Breeder Reactor Updated Design For a Helium Circulator Test Facility", dated April 1979 was asumed to be representative of the costs that would be required, on a dollars per square foot basis, for a new facility. To make this more representative, the building cost was reduced by removing the expensive overhead crane and deep pit required for the vertical orientation of that circulator. The cost per square foot was then determined, assuming a productivity factor of 1.0 , and multiplied by the square footage of the HTGR-HCTF to arrive at an approximation to the cost of a new building to house the test equipment for the horizontal circulator. This cost was then escalated forward to october 1 , 1979 dollars. The utilities and site preparation for this new facility were assumed functionally the same as for the GA-Al5300 facility, to have a productivity factor of 1.0 for all craft labor and costs escalated forward to October 1, 1979. Equipment and installation costs were assumed the same as for the modified HTGR-HCTF except that labor was adjusted for a productivity factor of 1.0 .

Engineering costs were assumed to be the same as for the modified IITGR-HCTF. The racional for this assumption was that engineering for a modified facility would normally be more per unit of construction cost than for a new facility and therefore the total cost would not be much different (unescalated).

A construction schedule, analogous to that in GA-A15300 was employed because it would not be possible to construct the new building within the 
construction schedule of the modified HTGR-HCTF. The same yearly escalation factors as employed for the modified HTGR-HCTF were employed to adjust both construction and eng ineering. $\Rightarrow$

Finally, the contingency was assumed to be $25 \%$. This allows a downward reduction of $5 \%$ for the fact that fast track construction would not be employed, but increases the contingency by $5 \%$ for the greater uncertainty assoclated with this approach to preparing a cost estimate.

\subsection{PROJECT COST SUMMARY}

The project cost summary presented here is consistent in organization and content with the summary for the modified HTGR-HCTF presented in Section 7.2 of this document and can be compared directly. 
TABLE $10-1$

NEW GCFR HELIUM CIRCULATOR TEST FACILITY TOTAL ESTIMATED COST SURMARY

Base Cost - October 1979 Dollars

Escalation - As Spent Thousands of Dollars

Architect

GAC

Total

Engineer

A. Engineering

Title I

Title II

Title III \& Project Administration
622

1,535

744

0

B, Land and Land Rights

C. Construction Costs

1. Improvement to Land

2. Building

3. Other Structures

4. Special Facilities

a. Test Systems

Helium Loop

Rapid Depressurization System

Instrumentation and Control

b. Support Systems

Dowtherm System

Helium Supply dud Storage system

Buffer Helium System

Nitrogen System

Vacuum System

Compressed Air System

High Purity Water

Cooling Water System

Electrical Power System
3,751

115

474

596

526

80

60

25

163

40

558

1,650
3,751

115

1,264 . 
NEW GCFR HELIUM CIRCULATOR TEST FACILITY TOTAL ESTIMATED COST SUMMLARY (CONT.)
Architect
GAC
Total
Engineer
c. Test Hardware
Installation
565
$-$
565
Handling Equipment
$-$
320
a. Electrical
831
831
b. Other Utilities
68
68
Sub-total
15,110
2,669
17,779
3,778
667
4,445
Sub-total
18,888
3,336
22,224
Construction Planning \& Design (CP\&D)
420
Total Estimated Cost of Facility
22,644

5. Utilities

Contingency $25 \%$ 
TABLE $10-2$

NEW GCFR - HELIUN CIRCULATOR TEST FACILITY

FACILITY FINANCIAL SCHEDULE.

FOR GAC FACILITY

(As Spent Dollars in Thousands)

Engineering Equipment $\underline{\text { Construction }}$

$F Y-79$
$F Y-80$
$F Y-81$

FY -82

1,640

600

$100^{(1)}$

100

FY -83

1,315

628 *

1,328

3,271

FY -84

366

1,781 *

7,966

10,113

FY -85

305

$328 *$

$\underline{5,967}$

6,600

Total

3,626

3,757

15,261

22,644

(1) Construction Planning \& Design, CP\&D

* Timing of expenditures estimated by RMP 


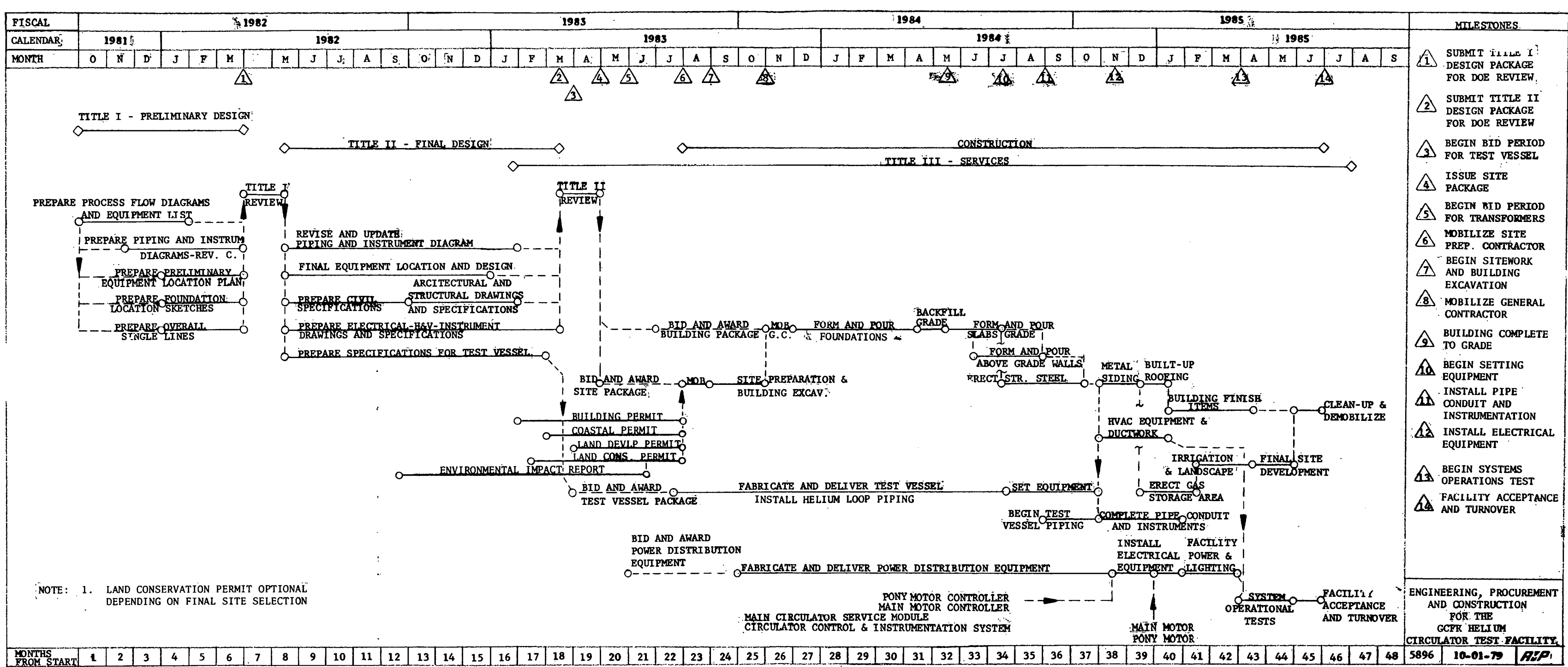

